\title{
DINOSTRAT: A global database of the stratigraphic and paleolatitudinal distribution of Mesozoic-Cenozoic organic-walled dinoflagellate cysts
}

5 Peter K. Bijl

Department of Earth Sciences, Utrecht University, Utrecht, 3584 CB, the Netherlands

Correspondence to: Peter K. Bijl (p.k.bijl@uu.nl)

10 Abstract. Mesozoic-Cenozoic organic-walled dinoflagellate cyst (dinocyst) biostratigraphy is a crucial tool for relative and absolute age control in complex ancient sedimentary systems. However, stratigraphic ranges of dinocysts are found to be strongly diachronous geographically. A global compilation of state-of-the-art calibrated regional stratigraphic ranges could assist in quantifying regional differences and evaluate underlying causes. For this reason, DINOSTRAT is here initiated - an open source, iterative, community-fed database intended to house all regional chronostratigraphic calibrations of dinocyst

15 events (https://github.com/bijlpeter83/DINOSTRAT.git). DINOSTRAT version 1.0 includes $>8500$ entries of first and last occurrences (collectively called "events") of $>1900$ dinocyst taxa, and their absolute ties to the chronostratigraphic time scale of Gradstein et al., 2012. Entries are derived from 199 publications and 189 sedimentary sections. DINOSTRAT interpolates paleolatitudes of regional dinocyst events, allowing evaluation of the paleolatitudinal variability of dinocyst event ages. DINOSTRAT allows for open accessibility and searchability, on region, age, and taxon. This paper presents a selection of the data in DINOSTRAT: (1) the (paleo)latitudinal spread and evolutionary history of modern dinocyst species; (2) the evolutionary patterns and paleolatitudinal spread of dinoflagellate cyst (sub)families; (3) a selection of key dinocyst events which are particularly synchronous. Although several dinocysts show - at the resolution of their calibration - quasisynchronous event ages, indeed many species have remarkable diachroneity. DINOSTRAT provides the data storage approach by which the community can now start to relate diachroneity to (1) inadequate tie to chronostratigraphic time scales; (2) complications in taxonomic concepts and (3) ocean connectivity and/or the affinities of taxa to environmental conditions.

\section{Introduction}

Over 50 years of research efforts have established a framework to use organic-walled dinoflagellate cysts (dinocysts) as biostratigraphic and chronostratigraphic tool. Dinocyst biostratigraphy is particularly applied to sediments which are difficult to date otherwise, such as restricted/nearshore marine settings (e.g., Poulsen et al., 1994; Brinkhuis et al., 1998; Iakovleva et

30 al., 2001; Śliwińska et al., 2012; Clyde et al., 2014), and polar regions (e.g., Sluijs et al., 2006; Bijl et al., 2013a; Houben et al., 2013; Radmacher et al., 2015; Śliwińska et al., 2020). As with all biostratigraphy, the reliability of dinocyst biostratigraphy 
heavily depends on the accuracy, precision, and regional consistency of the absolute ages of first and last stratigraphic occurrences (hereafter jointly referred to as "events") of easily recognized taxa. Through the past decades, absolute ages of dinocyst events were increasingly better chronostratigraphically constrained, using independent age control from magnetostratigraphy (e.g., Brinkhuis et al., 1992; Powell et al., 1996), other biostratigraphic tools (e.g., Davey, 1979; Leereveld, 1997; Oosting et al., 2006; Awad and Oboh-Ikenobe, 2019), and astrochronology (Versteegh, 1997). However, efforts to globally compile the chronostratigraphic calibration of dinocyst events revealed strong diachroneity for many species, between broad latitudinal bands, and endemism of many species within latitudinal bands (e.g., Williams et al., 2004). Because this impacts the development of quasi-global dinocyst zonation schemes, as has been proposed for other microfossil groups (e.g., Martini, 1971; Gradstein et al., 2020), the question is how the research field of dinocyst biostratigraphy should prog ress. Two questions arise from the notion of geographic diachroneity of dinocyst events:

- What kind of error or uncertainty should be applied to the absolute ages of events? Now that diachroneity has been demonstrated, the next step is to quantify the uncertainty in absolute ages of dinocyst events for each species, and to assess regional consistency. This is particularly important when calibrated species ranges are geographically extrapolated over large distances. And a related question: What is the impact of regional variability in absolute ages of events on the regional consistency of the stratigraphic order of events?

- What are the underlying causes for the observed diachroniety? Broadly, 3 reasons could apply: (1) inaccurate or inadequate tie of dinocyst events to the chronostratigraphic time scale, which leads to apparent (but perhaps false) diachroniety of species events between sites; (2) complexities in taxonomic concepts could obscure comparison of species ranges between sites. This aspect relates to the ease by which subtle morphological differences between species can be recognized (e.g., Hoyle et al., 2019). It also relates to the question whether the last occurrence of a fossil dinocyst taxon reflects extinction of its producer, adjustment of cyst morphology by its producer (e.g., Rochon et a., 2009), or a change in its life cycle strategy (e.g., towards less-preservable pellicle cysts; Bravo and Figueroa, 2014); (3) finally, paleoenvironmental/paleoceanographic conditions can impact species occurrence: ocean connectivity (Van Simaeys et al., 2005; Bijl et al., 2013b; Van Helmond et al., 2016), leads and lags in the biotic response to climate change (e.g., Sluijs et al., 2007) or the temperature affinity of dinocyst taxa (Van Simaeys et al., 2005; Van Helmond et al., 2016). For instance, in geologic time intervals of global climate cooling, warm-loving plankton species have diachronous last occurrences (LOs) which are progressively later at lower latitudes. A good example is the modern occurrence in the western Pacific warm pool of Dapsilidinium pastielsii, a species that was long thought to be extinct in the Pliocene (Head et al., 1989). This is exemplary for how important it is to assume asynchronous biostratigraphic events as potential paleoceanographic signal, or a signal of paleoecologic affinity, rather than biostratigraphic error.

A process towards answering these, and improving the accuracy of dinocyst biostratigraphy, requires a data compilation 
the means of chronostratigraphic calibration. It further requires that such data compilations are constantly updated to new insights: updated geologic time scales and bio- magnetostratigraphic zonation schemes, altered taxonomic concepts, new age models of sections, new stratigraphic sections. A complication on a logistical front, is that dinocyst ranges are typically published in the closed-access peer-review literature, which are not easily accessible to all, are inconsistent in their approach, and not easily updated to new insights.

This paper initiates DINOSTRAT, an open-source, online platform intended to house, disseminate, and iteratively update all published chronostratigraphic calibrations of dinoflagellate cyst ranges: the way in which they are tied to the chronostratigraphic time scale and the (paleo-) geographic position of the site from which they were calibrated. DINOSTRAT version 1.0 currently contains over 8500 entries of first and last occurrences of over 1900 dinoflagellate cyst taxa to the international time scale. These entries originate from 199 peer-reviewed papers presenting data from 189 sites. Including as many reports/sites as possible, with verifiable independent age control, and their latitudinal evolution through time, allows for proper evaluation of error and uncertainty. DINOSTRAT will allow to assess and quantify regional variability/consistency in event ages and provides the basic information to evaluate the paleoceanographic signal that diachroniety may hold. Open accessibility of the basic dinocyst stratigraphic data would further allow a proper evaluation and update of evolutionary patterns

80 in dinocyst families (McRae et al., 1996) with full disclosure of the underlying data. The approach on paper selection, data entry and calculations of ages and paleolatitudes is explained in Section 2. Section 3 presents examples of calibrated dinoflagellate cyst events: the stratigraphic and paleolatitudinal distribution of selected modern dinoflagellate cysts, and that of extant and extinct dinocyst families, with selected taxa highlighted. Section 4 discusses the implications of the DINOSTRAT approach and further directions. This paper represents the start of a community-fed data assembly approach to iteratively improve regional constraints on dinoflagellate cyst biostratigraphy.

\section{Approach}

DINOSTRAT version 1.0 represents a compilation of dinocyst events from peer-reviewed literature, with a publication date predating January $1^{\text {st }}, 2021$ (see Table 1). The taxonomic nomenclature, supra-generic classification and synonymy cited in Williams et al. (2017) is followed. One inherent assumption in the initial setup of DINOSTRAT is that the authors of the

90 reviewed literature have applied a consistent taxonomic framework. DINOSTRAT reports events of dinocyst species as they were presented in the papers, but applying the synonymy index of Williams et al., 2017. Most dinoflagellate cyst species are easily recognized, have a stable morphology (both regionally and through time) and clearly defined species concepts. However, some species (and subspecies) diagnoses are more subtle or represent endmembers in a continuum (e.g., Hoyle et al., 2019), in part imposed by the environmental conditions (e.g., Ellegaard, 2000). Some authors tend to lump species in complexes,

95 while others split into subspecies. The international recognition of these lumps and splits may have evolved through time, and may have restricted, regional significance only. Therefore, subtle differences in species concept interpretation may exist 
between authors and regions, which the current approach was unable to account for, and is considered a next step, when individual studies or sites are revisited.

For the subfamily Wetzelielloideae, DINOSTRAT deviates from the taxonomic index of Williams et al. (2017). The fundamental redefinition of species concepts in the taxonomic revisions for the Wetzelielloideae (Williams et al., 2015) eliminates many stratigraphically useful Eocene dinocyst taxa (Bijl et al., 2016). Therefore, for this subfamily, the calibration of dinocyst species is presented in the taxonomic classification of Wetzelielloideae prior to (Williams et al., 2015).

Table 1: Papers used in this review. Reference, Geography, Age base and Age top (in Ma), Tier (see Figure 1) and means of calibration to the Geologic Time Scale (GTS).

\begin{tabular}{|c|c|c|c|c|c|}
\hline Reference & $\begin{array}{l}\text { Geography } \\
\text { (location) }\end{array}$ & $\begin{array}{l}\text { Age } \\
\text { base }\end{array}$ & $\begin{array}{l}\text { Age } \\
\text { top }\end{array}$ & Tier & Calibrated to \\
\hline Açikalin et al., 2015 & NW Turkey & 67 & 65 & 3 & $\begin{array}{l}\text { planktonic foraminifera stratigraphy on the same } \\
\text { section }\end{array}$ \\
\hline Århus et al., 1989 & Norway & 166 & 155 & 3 & $\begin{array}{l}\text { Russian Platform zones, converted to Boreal } \\
\text { ammonite zones (see Supplement 1) }\end{array}$ \\
\hline Aubry et al., 2020 & $\begin{array}{l}\text { Labrador Sea, } \\
\text { Greenland }\end{array}$ & 3.2 & 2.25 & 1 & $\begin{array}{l}\text { Magnetostratigraphy on the same samples. Magnetic } \\
\text { reversals were calibrated usingplanktonic } \\
\text { foraminifera and nannofossils }\end{array}$ \\
\hline $\begin{array}{l}\text { Awad and Oboh- } \\
\text { Ikenobe, } 2016\end{array}$ & $\begin{array}{ll}\text { Ivory } & \text { Coast } \\
\text { Margin } & \end{array}$ & 57 & 54 & 3 & CP nannoplankton stratigraphy on the same section \\
\hline $\begin{array}{l}\text { Awad and Oboh- } \\
\text { Ikenobe, } 2019\end{array}$ & $\begin{array}{ll}\text { Ivory } & \text { Coast } \\
\text { Margin } & \end{array}$ & 28 & 16 & 3 & $\mathrm{CP} / \mathrm{CN}$ nannofossil stratigraphy on the same samples \\
\hline Bailey et al., 1997 & UK & 157 & 152 & 3 & $\begin{array}{l}\text { Boreal ammonite stratigraphy from the same core } \\
\text { samples. }\end{array}$ \\
\hline Baruffini et al., 2002 & S Italy & 35 & 32 & 3 & CP nannoplankton stratigraphy from the same study \\
\hline Besems, 1992 & Borneo & 65 & 0 & 5 & $\begin{array}{l}\text { chronostratigraphy, no independent age controll } \\
\text { shown (Industry data) }\end{array}$ \\
\hline Biffi and Manum, 1988 & Central Italy & 36 & 22 & 3 & $\begin{array}{l}\mathrm{NP} / \mathrm{NN} \text { nannoplankton and } \mathrm{N} / \mathrm{P} \text { planktonic } \\
\text { foraminifer stratigraphies from the same sections }\end{array}$ \\
\hline $\begin{array}{l}\text { Bijl and Brinkhuis, } \\
2015\end{array}$ & East Antarctica & 54 & 47 & 2 & $\begin{array}{l}\text { Magnetostratigraphy on the same section. } \\
\text { Magnetochrons are dated using dinocyst } \\
\text { biostratigraphy }\end{array}$ \\
\hline
\end{tabular}




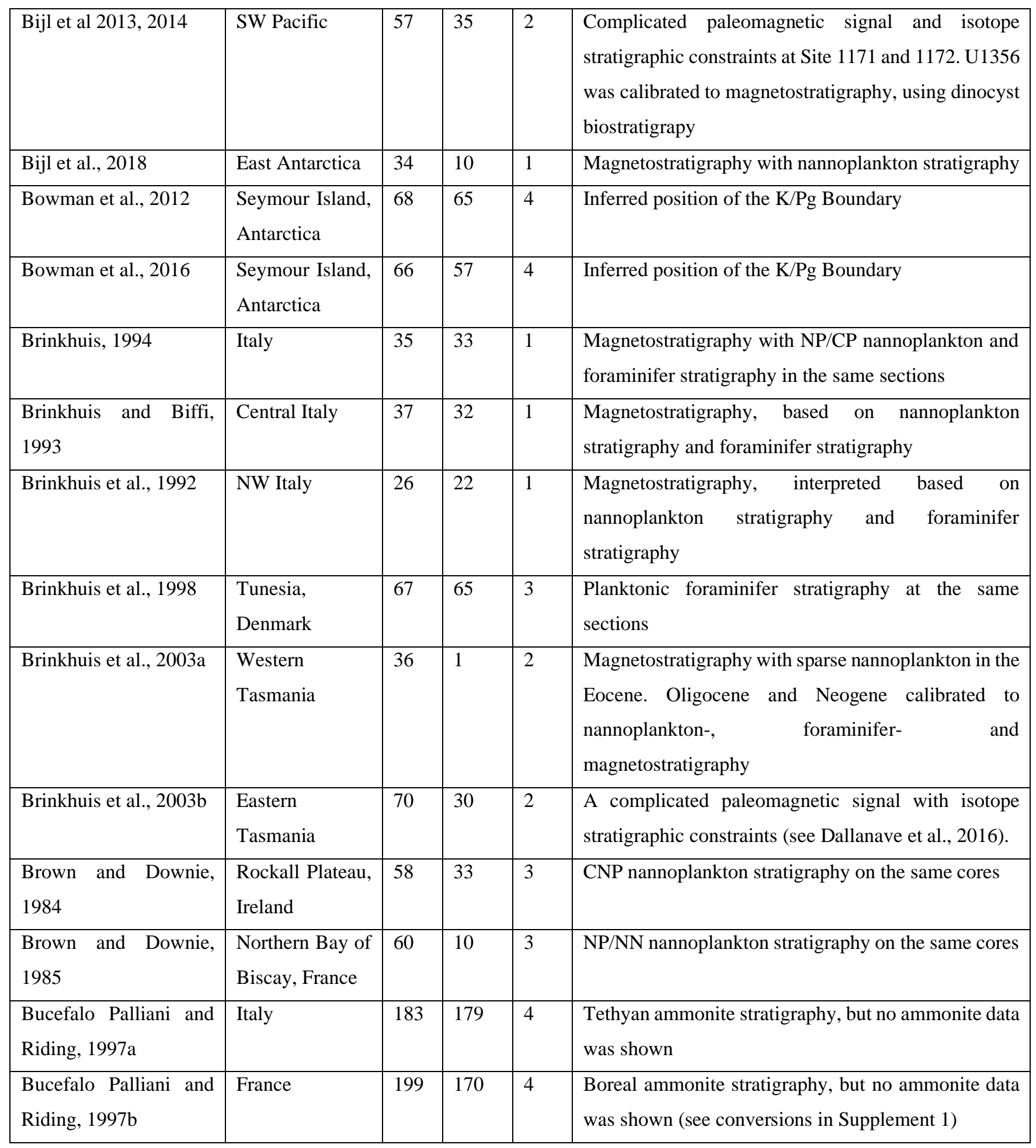




\begin{tabular}{|c|c|c|c|c|c|}
\hline $\begin{array}{l}\text { Bucefalo Palliani and } \\
\text { Riding, } 2000\end{array}$ & UK & 200 & 179 & 4 & $\begin{array}{l}\text { Tethyan ammonite stratigraphy, but no ammonite data } \\
\text { was shown (see conversions in Supplement 1) }\end{array}$ \\
\hline $\begin{array}{l}\text { Bucefalo Palliani and } \\
\text { Riding, } 2003\end{array}$ & Boreal/Tethys & 191 & 180 & 4 & $\begin{array}{l}\text { Boreal ammonite stratigraphy, but no ammonite data } \\
\text { was shown. }\end{array}$ \\
\hline $\begin{array}{l}\text { Bujak and Matsuoka, } \\
1986\end{array}$ & $\begin{array}{l}\text { North Pacific, } \\
\text { Japan }\end{array}$ & 23 & 0 & 5 & $\begin{array}{l}\text { Independent age constraints from planktonic } \\
\text { foraminifera, radiolaria, diatoms and nannoplankton } \\
\text { are not shown in the paper. }\end{array}$ \\
\hline Bujak and Mudge, 1994 & North Sea, UK & 57 & 53 & 4 & $\begin{array}{l}\text { Synthesis. Plots dinocyst events against NP } \\
\text { nannoplankton and } \mathrm{P} \text { planktonic foraminifer } \\
\text { stratigraphy not presenting independent stratigraphic } \\
\text { data. }\end{array}$ \\
\hline Correia et al., 2019 & Portugal & 183 & 168 & 3 & Tethyan ammonite stratigraphy on the same sections. \\
\hline Costa and Davey, 1992 & North Sea, UK & 145 & 66 & 4 & $\begin{array}{l}\text { Ammonite zones are plotted but no ammonite data } \\
\text { was presented. Campanian-Maastrichtian events were } \\
\text { calibrated to stages (see conversions in Supplement 1) }\end{array}$ \\
\hline $\begin{array}{l}\text { Costa and Downie, } \\
1979\end{array}$ & N Atlantic & 58 & 5 & 3 & Nannoplankton stratigraphy on the same section \\
\hline Crouch et al., 2014 & New Zealand & 66 & 54 & 1 & $\begin{array}{l}\text { Magnetostratigraphy and NP nannoplankton } \\
\text { stratigraphy on the same samples }\end{array}$ \\
\hline $\begin{array}{l}\text { Dallanave et al., 2016; } \\
\text { Crouch et al., } 2020\end{array}$ & New Zealand & 54 & 46 & 1 & $\begin{array}{l}\text { Magnetostratigraphy and NP nannoplankton zones on } \\
\text { the same section }\end{array}$ \\
\hline Davey, 1979 & $\mathrm{~N}$ atlantic & 124 & 100 & 3 & Nannoplankton stratigraphy on the same section \\
\hline Davey, 1982 & Denmark & 152 & 125 & 3 & $\begin{array}{l}\text { Original stratigraphic account was based on } \\
\text { Ammonites, pelycepods and benthic foraminifera } \\
\text { (see conversions in Supplement } 1 \text { ) }\end{array}$ \\
\hline Davey, 2001 & UK & 134 & 131 & 3 & Boreal Ammonite stratigraphy on the section \\
\hline $\begin{array}{l}\text { Davey and Verdier, } \\
1971\end{array}$ & France & 113 & 103 & 4 & $\begin{array}{l}\text { Boreal ammonite stratigraphy, not shown (see } \\
\text { conversions in Supplement 1) }\end{array}$ \\
\hline $\begin{array}{l}\text { De Lira Mota et al., } \\
2020\end{array}$ & $\begin{array}{l}\text { Gulf Coast, } \\
\text { USA }\end{array}$ & 37 & 32 & 3 & NP nannofossil stratigraphy on the same samples \\
\hline $\begin{array}{l}\text { De Schepper and Head } \\
2008,2009\end{array}$ & North Atlantic & 6 & 0 & 1 & $\begin{array}{l}\text { Magnetostratigraphy, NN nannofossil stratigraphy } \\
\text { and N planktonic foraminifer stratigraphy }\end{array}$ \\
\hline
\end{tabular}




\begin{tabular}{|c|c|c|c|c|c|}
\hline $\begin{array}{l}\text { De Schepper et al., } \\
2017\end{array}$ & North Atlantic & 7 & 1 & 1 & Magnetostratigraphy on the same section \\
\hline $\begin{array}{l}\text { De Vernal and Mudie, } \\
1989\end{array}$ & $\begin{array}{l}\text { Labrador Sea, } \\
\text { Greenland }\end{array}$ & 5.5 & 0 & 3 & Shipboard NN nannofossil stratigraphy \\
\hline De Vernal et al., 1992 & North Atlantic & 1.5 & 0 & 1 & Magnetostratigraphy and NN nannofossil stratigraphy \\
\hline $\begin{array}{l}\text { De Verteuil and Norris, } \\
1996\end{array}$ & $\begin{array}{l}\text { Chesapeake } \\
\text { Bay, USA }\end{array}$ & 25 & 4 & 4 & $\begin{array}{l}\text { Synthesized stratigraphic data, no independent age } \\
\text { control presented }\end{array}$ \\
\hline $\begin{array}{l}\text { Dimter and Smelror, } \\
1990\end{array}$ & sw Germany & 166 & 163 & 3 & Boreal ammonite zonation on the same material \\
\hline Dodsworth, 2000 & USA and UK & 96 & 93 & 3 & $\begin{array}{l}\text { Planktonic foraminifer and ammonite stratigraphy on } \\
\text { the same section }\end{array}$ \\
\hline $\begin{array}{l}\text { Duffield and Stein, } \\
1986\end{array}$ & $\begin{array}{l}\text { Gulf Coast, } \\
\text { USA }\end{array}$ & 35 & 5 & 3 & N Planktonic foraminiferal zonation \\
\hline $\begin{array}{l}\text { Duque-Herrera et al., } \\
2018\end{array}$ & Colombia & 18 & 5 & 3 & NN nannofossil events in the same core \\
\hline Duxbury, 1983 & North Sea & 126 & 110 & 3 & $\begin{array}{l}\text { Boreal ammonite zonation (see conversions in } \\
\text { Supplement 1) }\end{array}$ \\
\hline Duxbury, 2001 & Scotland & 139 & 100 & 4 & $\begin{array}{l}\text { Boreal ammonite zonation, not directly from the well } \\
\text { cutting material (see conversions in Supplement 1) }\end{array}$ \\
\hline $\begin{array}{l}\text { Dybkjær and Piasecki, } \\
2008,2010\end{array}$ & Denmark & 23 & 0 & 3 & NP/NN nannoplankton stratigraphy \\
\hline Egger et al., 2016 & $\begin{array}{l}\text { Newfoundland, } \\
\text { USA }\end{array}$ & 35 & 21 & 1 & $\begin{array}{l}\text { Magnetostratigraphy with } \mathrm{NN} \text { nannoplankton } \\
\text { stratigraphy }\end{array}$ \\
\hline $\begin{array}{l}\text { Eldrett and Harding, } \\
2009\end{array}$ & $\begin{array}{l}\text { Voring Plateau, } \\
\text { Norwegian Sea }\end{array}$ & 52 & 33 & 2 & $\begin{array}{l}\text { Magnetostratigraphy on the same section, see Eldrett } \\
\text { et al., } 2004\end{array}$ \\
\hline Eldrett et al., 2004 & Norwegian Sea & 50 & 30 & 2 & $\begin{array}{l}\text { Magnetostratigraphy, but chrons } \text { were not } \\
\text { independently interpreted }\end{array}$ \\
\hline Eldrett et al., 2019 & North Atlantic & 34 & 24 & 2 & $\begin{array}{l}\text { Magnetostratigraphy on the same section, see Eldrett } \\
\text { et al., } 2004\end{array}$ \\
\hline Eshet et al., 1992 & Israel & 67 & 65 & 3 & NP nannoplankton strat at the same site \\
\hline $\begin{array}{l}\text { Feist-Burkhardt and } \\
\text { Monteil, } 1997\end{array}$ & France & 171 & 167 & 3 & $\begin{array}{l}\text { Calibrated to Boreal ammonite stratigraphy (see } \\
\text { conversions in Supplement } 1 \text { ) }\end{array}$ \\
\hline Feist-Burkhardt, 1990 & sw Germany & 174 & 168 & 3 & Boreal ammonite stratigraphy \\
\hline
\end{tabular}




\begin{tabular}{|c|c|c|c|c|c|}
\hline Fensome et al., 2008 & $\begin{array}{l}\text { Scotian Margin, } \\
\text { E Canada }\end{array}$ & 100 & 0 & 3 & $\begin{array}{l}\text { NN and NC nannoplankton stratigraphy, but because } \\
\text { based on cuttings, only LADs are given }\end{array}$ \\
\hline Firth et al., 2013 & North Atlantic & 51 & 32 & 1 & $\begin{array}{l}\text { Magnetostratigraphy with independent age control } \\
\text { from nannoplankton and planktonic foraminifer } \\
\text { stratigraphy }\end{array}$ \\
\hline Firth, 1996 & N Atlantic & 45 & 30 & 1 & $\begin{array}{l}\text { Calibrated using magnetostratigraphy from Eldrett et } \\
\text { al., } 2009\end{array}$ \\
\hline Frieling et al., 2014 & $\begin{array}{l}\text { West Siberian } \\
\text { Sea }\end{array}$ & 60 & 45 & 2 & $\begin{array}{l}\text { Magnetostratigraphy and stable carbon isotope } \\
\text { stratigraphy }\end{array}$ \\
\hline Gradstein et al., 1992 & North Sea, NL & 66 & 23 & 3 & $\begin{array}{l}\mathrm{N} / \mathrm{P} \text { foraminifer stratigraphy, but entered against NP } \\
\text { nannoplankton stratigraphy }\end{array}$ \\
\hline Grothe et al., 2017 & Black Sea & 6 & 5.5 & 1 & Magnetostratigraphy on the same section \\
\hline Guasti et al., 2005 & Tunisia & 66 & 57 & 3 & $\begin{array}{l}\text { NP nannoplankton and P foraminifer stratigraphy on } \\
\text { the same section }\end{array}$ \\
\hline Habib and Drugg, 1983 & East Coast USA & 157 & 138 & 1 & Magnetostratigraphy on the same section \\
\hline Habib and Drugg, 1987 & East Coast USA & 145 & 66 & 2 & Magnetostratigraphy on the same section \\
\hline Harding et al., 2011 & S Russia & 152 & 134 & 3 & $\begin{array}{l}\text { Russian ammonite zonation on the same sections, } \\
\text { correlated to Boreal ammonite zones (see conversions } \\
\text { in Supplement 1) }\end{array}$ \\
\hline Harland, 1979 & $\mathrm{~N}$ atlantic & 12 & 0 & 3 & Nannoplankton stratigraphy on the same section \\
\hline Harland, 1992 & North Sea & 23 & 0 & 4 & $\begin{array}{l}\text { NN nannoplankton and } \mathrm{N} \text { planktonic foraminifer } \\
\text { stratigraphy, but independent age constraints not } \\
\text { explicitly shown }\end{array}$ \\
\hline Head, 1998 & North Sea & 4 & 1.6 & 4 & Stages, using known ages of sampled formations \\
\hline Head and Norris, 1989 & $\begin{array}{l}\text { Western North } \\
\text { Atlantic }\end{array}$ & 57 & 23 & 3 & NN nannoplankton stratigraphy \\
\hline Head and Norris, 2003 & North Atlantic & 7 & 1 & 1 & $\begin{array}{l}\text { Magnetostrat and NC nannoplankton stratigraphy } \\
\text { from the same section }\end{array}$ \\
\hline Head et al., 1989 & Labrador Sea & 9 & 5 & 3 & $\begin{array}{l}\text { NN and CN nannoplankton stratigraphy at the same } \\
\text { site }\end{array}$ \\
\hline
\end{tabular}




\begin{tabular}{|c|c|c|c|c|c|}
\hline $\begin{array}{l}\text { Heilmann-Clausen, } \\
1985\end{array}$ & North Sea & 62 & 54 & 3 & NP nannofossil zones on the same section \\
\hline $\begin{array}{l}\text { Heilmann-Clausen, } \\
1987\end{array}$ & Danish basin & 152 & 100 & 4 & $\begin{array}{l}\text { Synthesis of records from the North Sea area. } \\
\text { Correlation to Boreal ammonite zones (see } \\
\text { conversions in Supplement 1) }\end{array}$ \\
\hline $\begin{array}{l}\text { Heilmann-Clausen and } \\
\text { Van Simaeys, } 2005\end{array}$ & $\begin{array}{l}\text { Danish North } \\
\text { Sea }\end{array}$ & 48 & 30 & 3 & NP nannofossil zonation \\
\hline $\begin{array}{l}\text { Helby and McMinn, } \\
1992\end{array}$ & NW Australia & 139 & 104 & 3 & $\mathrm{CC}$ nannofossil zonation on the same section \\
\hline Helby et al., 1987 & Australia & 241 & 66 & 4 & $\begin{array}{l}\text { Synthesis, calibrated to stages using industry } \\
\text { information. Albian-Danian has independent age } \\
\text { controll from foraminiferal and nannoplankton zones }\end{array}$ \\
\hline Hoek et al., 1996 & Israel & 73 & 69 & 3 & CC and UC nannofossil events \\
\hline Hollis et al., 2009 & New Zealand & 51 & 46 & 3 & NP nannofossil stratigraphy on the same section \\
\hline Houben et al., 2011 & $\begin{array}{l}\text { Falkland } \\
\text { Islands, } \quad \mathrm{S} \\
\text { Atlantic }\end{array}$ & 35 & 32 & 1 & $\begin{array}{l}\text { Oi-1 isotope event, the age of which is then transferred } \\
\text { to the GPTS }\end{array}$ \\
\hline Houben et al., 2019 & Alabama, USA & 37 & 30 & 1 & $\begin{array}{l}\text { Magnetostratigraphy and NP nannoplankton } \\
\text { stratigraphy on the same section }\end{array}$ \\
\hline $\begin{array}{l}\text { Iakovleva and } \\
\text { Heilmann-Clausen, } \\
2010\end{array}$ & Siberia & 52 & 35 & 2 & Magnetostratigraphy on the same section \\
\hline Ioannides et al., 1988 & France & 157 & 152 & 3 & $\begin{array}{l}\text { Boreal ammonite stratigraphy (see conversions in } \\
\text { Supplement 1) }\end{array}$ \\
\hline King et al., 2018 & Crimea & 59 & 48 & 3 & NP nannofossil stratigraphy on the same samples \\
\hline Kirsch, 1991 & $\begin{array}{l}\text { Bad Tolz, } \\
\text { Southern } \\
\text { Germany }\end{array}$ & 94 & 66 & 3 & Planktonic foraminifer stratigraphy, data not shown \\
\hline Köthe, 2012 & NW Germany & 65 & 0 & 3 & $\begin{array}{l}\text { NP nannoplankton stratigraphy in the same sections. } \\
\text { (for conversions see Supplement } 1 \text { ) }\end{array}$ \\
\hline Köthe et al., 1988 & Pakistan & 58 & 50 & 3 & Nannoplankton stratigraphy on the same sections \\
\hline Krijgsman et al., 1995 & $\begin{array}{l}\text { Mediterranean } \\
\text { (Gibliscemi) }\end{array}$ & 10 & 7 & 1 & $\begin{array}{l}\text { Magnetostratigraphy with planktonic foraminifer } \\
\text { stratigraphy on the same section }\end{array}$ \\
\hline
\end{tabular}




\begin{tabular}{|c|c|c|c|c|c|}
\hline Kuhlman et al., 2006 & $\begin{array}{l}\text { Central North } \\
\text { Sea }\end{array}$ & 4 & 0 & 1 & $\begin{array}{l}\text { Magnetostratigraphy with foraminifer stratigraphy on } \\
\text { the same section }\end{array}$ \\
\hline Lebedeva et al., 2013 & $\begin{array}{l}\text { Omsk, } \quad \text { sw } \\
\text { siberia }\end{array}$ & 83 & 68 & 1 & $\begin{array}{l}\text { Magnetostratigraphy and CC nannoplankton } \\
\text { stratigraphy on the same section }\end{array}$ \\
\hline Leereveld, 1995 & $\begin{array}{l}\text { Caravaca, } \\
\text { Southern Spain }\end{array}$ & 145 & 105 & 3 & $\begin{array}{l}\text { Tethyan ammonite stratigraphy on the same section } \\
\text { (for conversions see Supplement } 1 \text { ) }\end{array}$ \\
\hline Leereveld, 1997a & $\begin{array}{l}\text { Caravaca, } \\
\text { Southern Spain }\end{array}$ & 134 & 125 & 3 & $\begin{array}{l}\text { Tethyan ammonite stratigraphy on the same section } \\
\text { (for conversions see Supplement } 1 \text { ) }\end{array}$ \\
\hline Leereveld, 1997b & $\begin{array}{l}\text { Caravaca, } \\
\text { Southern Spain }\end{array}$ & 146 & 134 & 3 & Tethyan ammonite stratigraphy on the same section \\
\hline $\begin{array}{l}\text { Londeix and Jan Du } \\
\text { Chene, } 1998\end{array}$ & $\begin{array}{l}\text { Bordeaux, } \\
\text { France }\end{array}$ & 21 & 16 & 3 & NN nannoplankton stratigraphy \\
\hline Louwye et al., 2004 & Belgium & 6 & 0 & 3 & NN nannoplankton stratigraphy on the same section \\
\hline Louwye et al., 2008 & $\begin{array}{l}\text { Porcupine basin, } \\
\text { Ireland }\end{array}$ & 17 & 11 & 1 & Magnetostratigraphy on the same section \\
\hline Mao and Mohr, 1992 & $\begin{array}{l}\text { Kerguelen } \\
\text { Plateau, } \\
\text { Antarctica }\end{array}$ & 75 & 70 & 3 & CC nannofossil stratigraphy on the same section \\
\hline Marret et al., 2020 & global & 0 & 0 & & Surface sediment data \\
\hline Masure, 1988 & $\begin{array}{ll}\text { Ivory } & \text { Coast } \\
\text { Margin } & \end{array}$ & 140 & 112 & 3 & CC nannofossil stratigraphy on the same section \\
\hline Masure et al., 1998 & $\begin{array}{ll}\text { Ivory } & \text { Coast } \\
\text { Margin } & \end{array}$ & 90 & 57 & 3 & $\begin{array}{l}\text { CP and CC nannoplaknton stratigraphy on the same } \\
\text { section }\end{array}$ \\
\hline Matsuoka et al., 1987 & Japan & 20 & 0 & 3 & $\mathrm{~N}$ foraminifer events on the same section \\
\hline $\begin{array}{l}\text { Matthiessen and } \\
\text { Brenner, } 1996\end{array}$ & Spitsbergen & 3 & 0 & 1 & Magnetostratigraphy on the same section \\
\hline McLachlan et al., 2018 & western Canada & 77 & 71 & 1 & Magnetostratigraphy on the same site \\
\hline McMinn, 1992 & NW Australia & 16 & 3 & 3 & $\begin{array}{l}\mathrm{CP} \text { nannofossil stratigraphy and } \mathrm{N} \text { planktonic } \\
\text { foraminifer stratigraphy }\end{array}$ \\
\hline McMinn, 1993 & NW Australia & 9 & 0 & 3 & $\mathrm{CN}$ nannoplankton stratigraphy on the same section \\
\hline Mohr and Mao, 1997 & $\begin{array}{l}\text { Kerguelen and } \\
\text { Maud Rise, } \\
\text { Antarctica }\end{array}$ & 73 & 70 & 1 & Magnetostratigraphy, CC nannoplankton stratigraphy \\
\hline
\end{tabular}




\begin{tabular}{|c|c|c|c|c|c|}
\hline Montanari et al., 1997 & $\begin{array}{l}\text { Contessa, } \\
\text { Gubbio, Italy }\end{array}$ & 26 & 16 & 1 & $\begin{array}{l}\text { Magnetostratigraphy, foraminifer and nannoplankton } \\
\text { stratigraphy }\end{array}$ \\
\hline Monteil, 1992 & France & 152 & 134 & 3 & $\begin{array}{l}\text { Tethyan Ammonite stratigraphy. Partly overwritten by } \\
\text { Monteil, } 1993 \text { (for conversions see Supplement 1) }\end{array}$ \\
\hline Monteil, 1993 & France & 152 & 140 & 3 & $\begin{array}{l}\text { Some sections were calibrated to Tehyan ammonite } \\
\text { stratigraphy, some only indicated stages (for } \\
\text { conversions see Supplement 1) }\end{array}$ \\
\hline Mudge and Bujak, 1996 & North Sea & 66 & 33 & 3 & $\begin{array}{l}\text { Synthesis, using } \mathrm{P} \text { planktonic foraminifer and } \mathrm{NP} \\
\text { nannoplankton events in the same section, but no data } \\
\text { shown }\end{array}$ \\
\hline Mudge and Bujak, 2001 & Faroe-Shetland & 66 & 54 & 3 & $\begin{array}{l}\text { NP nannoplankton zones and P planktonic foraminifer } \\
\text { zones in the same sections, but no data shown }\end{array}$ \\
\hline Mudie, 1987 & North Atlantic & 8 & 0 & 1 & $\begin{array}{l}\text { Magnetostratigraphy, } \mathrm{N} \text { foraminifer strat and } \mathrm{NN} \\
\text { nannoplankton stratigraphy }\end{array}$ \\
\hline Nikitenko et al., 2008 & Siberia & 150 & 134 & 3 & $\begin{array}{l}\text { Siberian ammonite stratigraphy, in the paper } \\
\text { correlated to Tethyan ammonite zones (for } \\
\text { conversions see Supplement 1) }\end{array}$ \\
\hline $\begin{array}{l}\text { Nøhr-Hansen et al., } \\
2002\end{array}$ & West Greenland & 66 & 62 & 3 & NP nannofossil stratigraphy on the same section \\
\hline $\begin{array}{l}\text { Nøhr-Hansen et al., } \\
2020\end{array}$ & Greenland & 150 & 66 & 4 & $\begin{array}{l}\text { Ammonite zonation on the same sections, but } \\
\text { ammonite data shown separately. Calibrated to stages } \\
\text { herein }\end{array}$ \\
\hline Olde et al, 2015 & North Sea & 94 & 88 & 3 & Boreal ammonite stratigraphy on the same section \\
\hline Oosting et al., 2006 & Australia & 131 & 120 & 4 & $\begin{array}{l}\text { Tethyan ammonite stratigraphy on Angles, then } \\
\text { inferred for Site } 263 \text { (for conversions see Supplement } \\
\text { 1) }\end{array}$ \\
\hline Pearce, 2010 & UK & 95 & 70 & 4 & $\begin{array}{l}\text { UK ammonite zonations in nearby outcrops. Some } \\
\text { intervals could not be correlated to the GTS } 2012\end{array}$ \\
\hline Piasecki et al., 1992 & Greenland & 65 & 57 & 3 & NP Nannofossil stratigraphy on the same section \\
\hline $\begin{array}{l}\text { Poulsen and Riding, } \\
2003\end{array}$ & North Sea, UK & 210 & 137 & 4 & $\begin{array}{l}\text { Synthesis of Danish and British dinocyst events. } \\
\text { Calibrated to Boreal ammonite stratigraphy, but } \\
\text { presented, and herein plotted against stages }\end{array}$ \\
\hline Poulsen, 1992 & Denmark & 163 & 145 & 4 & Boreal ammonite stratigraphy. Synthesis \\
\hline
\end{tabular}




\begin{tabular}{|c|c|c|c|c|c|}
\hline Poulsen, 1998 & Poland & 169 & 164 & 3 & Boreal and Tethyan ammonite zones \\
\hline Powell et al., 1996 & North Sea, UK & 59 & 55 & 1 & Magnetostratigraphy on the same sections \\
\hline Powell, 1986 & NW Italy & 25 & 21 & 3 & NP nannofossil stratigraphy on the same section \\
\hline Powell, 1988 & $\begin{array}{l}\text { Central North } \\
\text { Sea }\end{array}$ & 63 & 54 & 3 & $\begin{array}{l}\text { NP nannofossil stratigraphy on the same sediments, no } \\
\text { nannoplankton data directly shown }\end{array}$ \\
\hline Powell in Powell, 1992 & North Sea, UK & 66 & 23 & 4 & $\begin{array}{l}\mathrm{P} \text { planktonic foraminifer and NP nannofossil } \\
\text { stratigraphy, no direct calibration data shown }\end{array}$ \\
\hline Prince et al., 2008 & UK & 89 & 83 & 3 & $\begin{array}{l}\text { UK ammonite stratigraphy on the same sections, } \\
\text { herein correlated to GTS } 2012\end{array}$ \\
\hline Pross et al., 2010 & Italy & 35 & 22 & 1 & $\begin{array}{l}\text { Magnetostratigraphy and independent age control } \\
\text { from NP nannoplankton stratigraphy }\end{array}$ \\
\hline $\begin{array}{ll}\text { Quaijtaal and } & \\
\text { Brinkhuis, } 2012\end{array}$ & Alabama, USA & 37 & 30 & 1 & $\begin{array}{l}\text { Magnetostratigraphy from the same section, } \\
\text { independently established using nannoplankton and } \\
\text { foraminifer stratigraphy }\end{array}$ \\
\hline Quaijtaal et al., 2014 & $\begin{array}{l}\text { Porcupine basin, } \\
\text { Ireland }\end{array}$ & 17 & 11 & 1 & $\begin{array}{l}\text { Magnetostratigraphy from the same section, } \\
\text { independently established using nannoplankton } \\
\text { stratigraphy }\end{array}$ \\
\hline Radmacher et al., 2014a & Barentz Sea & 101 & 71 & 4 & Ages of the lithostratigraphic framework \\
\hline $\begin{array}{l}\text { Radmacher et al., } \\
2014 b\end{array}$ & Zumaia, Spain & 74 & 70 & 1 & $\begin{array}{l}\text { Magnetostratigraphy and UC nannoplankton } \\
\text { stratigraphy on the same section }\end{array}$ \\
\hline Radmacher et al., 2015 & Norwegian Sea & 113 & 66 & 4 & $\begin{array}{l}\text { Regional lithostratigraphy dated using foraminifers } \\
\text { and nannoplankton, but no direct independent age } \\
\text { constraints shown }\end{array}$ \\
\hline $\begin{array}{l}\text { Riding and Helby, } \\
\text { 2001a-g }\end{array}$ & NW Australia & 182 & 100 & 4 & $\begin{array}{l}\text { Nannofossil and ammonite stratigraphy, but with } \\
\text { some correlation to European and Tethyan sections } \\
\text { (for conversions see Supplement } 1 \text { ) }\end{array}$ \\
\hline $\begin{array}{l}\text { Riding and Thomas, } \\
1988\end{array}$ & UK & 160 & 150 & 3 & $\begin{array}{l}\text { Boreal ammonite zonation on the same section (for } \\
\text { conversions see Supplement 1) }\end{array}$ \\
\hline $\begin{array}{l}\text { Riding and Thomas in } \\
\text { Powell, } 1992\end{array}$ & North Sea & 202 & 145 & 4 & $\begin{array}{l}\text { Boreal ammonite zonations, but not directly shown in } \\
\text { paper (for conversions see Supplement 1) }\end{array}$ \\
\hline $\begin{array}{l}\text { Riding and Thomas, } \\
1997\end{array}$ & $\begin{array}{l}\text { N Scotland, isle } \\
\text { of Skye }\end{array}$ & 166 & 155 & 3 & $\begin{array}{l}\text { Boreal ammonite stratigraphy on the same section (for } \\
\text { conversions see Supplement 1) }\end{array}$ \\
\hline
\end{tabular}




\begin{tabular}{|c|c|c|c|c|c|}
\hline Riding et al, 2010 & Australia & 237 & 145 & 4 & $\begin{array}{l}\text { Ammonites, conodonts, Belemnite/bivalve, } \mathrm{NJ} \\
\text { nannoplankton stratigraphy and strontium isotopes, } \\
\text { but these data are not shown in the paper }\end{array}$ \\
\hline Riley and Fenton, 1982 & UK/France & 166 & 160 & 3 & Boreal ammonite stratigraphy on the same sections \\
\hline Schiøler, 1993 & Denmark & 72 & 66 & 4 & $\begin{array}{l}\text { Stages, independent age constraints come from } \\
\text { calcareous microplankton, not shown }\end{array}$ \\
\hline $\begin{array}{ll}\text { Schreck } & \text { and } \\
\text { Matthiessen, } 2014 & \end{array}$ & $\begin{array}{l}\text { Northern } \\
\text { Iceland }\end{array}$ & 14 & 5 & 1 & $\begin{array}{l}\text { Magnetostratigraphy with } \mathrm{NN} \text { nannoplankton and } \\
\text { diatom stratigraphy }\end{array}$ \\
\hline Schreck et al., 2012 & $\begin{array}{l}\text { Northern } \\
\text { Iceland }\end{array}$ & 15 & 2 & 1 & $\begin{array}{l}\text { Magnetostratigraphy with } \mathrm{NN} \text { nannoplankton and } \\
\text { diatom stratigraphy }\end{array}$ \\
\hline Schreck et al., 2013 & $\begin{array}{l}\text { Northern } \\
\text { Iceland }\end{array}$ & 15 & 2 & 1 & $\begin{array}{l}\text { Magnetostratigraphy with } \mathrm{NN} \text { nannoplankton and } \\
\text { diatom stratigraphy }\end{array}$ \\
\hline Schreck et al., 2017 & $\begin{array}{l}\text { Northern } \\
\text { Iceland }\end{array}$ & 15 & 2 & 1 & $\begin{array}{l}\text { Magnetostratigraphy with } \mathrm{NN} \text { nannoplankton and } \\
\text { diatom stratigraphy }\end{array}$ \\
\hline Shulgina et al., 1994 & Siberia & 145 & 132 & 3 & $\begin{array}{l}\text { Boreal ammonite stratigraphy on the same sections } \\
\text { (for conversions see Supplement 1) }\end{array}$ \\
\hline Skupien, 2004 & Slovakia & 123 & 99 & 3 & $\begin{array}{l}\text { Boreal ammonite stratigraphy (for conversions see } \\
\text { Supplement 1) }\end{array}$ \\
\hline $\begin{array}{l}\text { Skupien and Vašíček, } \\
2002\end{array}$ & Czech republic & 131 & 113 & 3 & $\begin{array}{l}\text { Tethyan ammonite stratigraphy on the same section } \\
\text { (for conversions see Supplement 1) }\end{array}$ \\
\hline $\begin{array}{l}\text { Slimani and Louwye, } \\
2011\end{array}$ & Belgium & 75 & 62 & 4 & $\begin{array}{l}\text { Regional lithostratigraphy calibrated to belemnite } \\
\text { stratigraphy, tied to type Maastrichtian }\end{array}$ \\
\hline Śliwińska et al., 2012 & $\begin{array}{l}\text { Danish North } \\
\text { Sea }\end{array}$ & 34 & 25 & 1 & $\begin{array}{l}\text { Magnetostratigraphy and NP nannoplankton on the } \\
\text { same section }\end{array}$ \\
\hline Sluijs et al., 2003 & Tasmania & 37 & 30 & 2 & $\begin{array}{l}\text { Magnetostratigraphy on the same section, but no } \\
\text { independent chron assignment }\end{array}$ \\
\hline Smelror et al., 1991 & Spain & 168 & 158 & 3 & $\begin{array}{l}\text { Tethyan ammonite stratigraphy on the same section } \\
\text { (for conversions see Supplement 1) }\end{array}$ \\
\hline Smelror, 1988a & Greenland & 167 & 160 & 3 & $\begin{array}{l}\text { Boreal ammonite stratigraphy on the same section (for } \\
\text { conversions see Supplement 1) }\end{array}$ \\
\hline Smelror, $1988 b$ & $\begin{array}{l}\text { Svalbard, } \\
\text { Norway }\end{array}$ & 168 & 160 & 3 & $\begin{array}{l}\text { NW European ammonite stratigraphy, herein } \\
\text { calibrated to the Boreal zonation (for conversions see } \\
\text { Supplement 1) }\end{array}$ \\
\hline
\end{tabular}




\begin{tabular}{|c|c|c|c|c|c|}
\hline Smelror, 1994 & Swabia & 167 & 165 & 4 & $\begin{array}{l}\text { Ammonite and foraminifer stratigraphy, but herein } \\
\text { calibrated against stages }\end{array}$ \\
\hline Smelror and Dietl, 1994 & s Germany & 167 & 165 & 3 & Boreal ammonite stratigraphy on the same section \\
\hline $\begin{array}{ll}\text { Smelror } & \text { and } \\
\text { Lominadze, } 1989 & \end{array}$ & Caucasus & 166 & 163 & 3 & $\begin{array}{l}\text { Boreal ammonite stratigraphy from the same section } \\
\text { (for conversions see Supplement } 1 \text { ) }\end{array}$ \\
\hline Soliman et al., 2012 & $\begin{array}{l}\text { Golf of Suez, } \\
\text { Egypt }\end{array}$ & 54 & 14 & 3 & $\begin{array}{l}\text { NP/NN nannoplankton stratigraphy on the same } \\
\text { section }\end{array}$ \\
\hline Steeman et al., 2020 & Angola & 60 & 35 & 3 & $\mathrm{P} / \mathrm{E}$ foraminifer stratigraphy on the same section \\
\hline $\begin{array}{l}\text { Stover and Hardenbol, } \\
1994\end{array}$ & Belgium & 34 & 28 & 3 & NP nannoplankton stratigraphy on the same sections \\
\hline Strauss and Lund, 1992 & Germany & 18 & 6 & 3 & Nannoplankton stratigraphy on the same sections \\
\hline Thorn et al, 2009 & $\begin{array}{l}\text { Seymour Island, } \\
\text { Antarctica }\end{array}$ & 68 & 65 & 4 & The position of the K-Pg boundary \\
\hline Tocher, 1987 & $\begin{array}{l}\text { New Jersey } \\
\text { Shelf, USA }\end{array}$ & 73 & 66 & 3 & $\begin{array}{l}\text { Planktonic foraminifer stratigraphy on the same } \\
\text { samples }\end{array}$ \\
\hline Tocher and Jarvis, 1994 & $\begin{array}{l}\text { Fumichon, } \\
\text { France }\end{array}$ & 100 & 95 & 3 & Boreal ammonite stratigraphy on the same section \\
\hline Tocher and Jarvis, 1995 & NW France & 101 & 92 & 3 & Boreal ammonite stratigraphy on the same section \\
\hline Tocher and Jarvis, 1996 & $\begin{array}{l}\text { NW France and } \\
\text { SW UK }\end{array}$ & 110 & 95 & 3 & $\begin{array}{l}\text { Boreal ammonite stratigraphy on the same section (for } \\
\text { conversions see Supplement } 1 \text { ) }\end{array}$ \\
\hline Torricelli, 2000 & southern Italy & 131 & 100 & 1 & $\begin{array}{l}\text { Integrated bio-magneto-cyclostratigraphic } \\
\text { framework, but only stages shown in the paper }\end{array}$ \\
\hline Torricelli, 2006 & Piobbico, Italy & 113 & 100 & 3 & NC nannoplankton stratigraphy on the same section \\
\hline $\begin{array}{l}\text { Torricelli and Amore, } \\
2003\end{array}$ & Southern Italy & 101 & 72 & 3 & CC nannoplankton stratigraphy on the same section \\
\hline Torricelli et al., 2006 & $\begin{array}{l}\text { Tremp Basin, } \\
\text { Northern Spain }\end{array}$ & 53 & 51 & 3 & $\begin{array}{l}\text { (P) planktonic foraminifer and NP nannoplankton } \\
\text { stratigraphy on the same section }\end{array}$ \\
\hline Türkecan et al., 2018 & Turkey & 18 & 14 & 3 & $\begin{array}{l}\text { NN nannofossil and } M \text { foraminifer stratigraphy from } \\
\text { the same section }\end{array}$ \\
\hline $\begin{array}{l}\text { Van de Schootbrugge et } \\
\text { al., 2019a }\end{array}$ & UK, Arctic & 189 & 174 & 3 & Boreal ammonite stratigraphy on the same section \\
\hline
\end{tabular}




\begin{tabular}{|c|c|c|c|c|c|}
\hline $\begin{array}{l}\text { Van de Schootbrugge et } \\
\text { al., 2019b }\end{array}$ & $\begin{array}{l}\text { northern } \\
\text { Germany }\end{array}$ & 202 & 178 & 3 & Boreal ammonite stratigraphy \\
\hline $\begin{array}{l}\text { Van Mourik and } \\
\text { Brinkhuis, } 2005\end{array}$ & Italy & 37 & 33 & 1 & Magnetostratigraphy on the same section \\
\hline Van Mourik et al., 2001 & Offshore Florida & 39 & 35 & 1 & $\begin{array}{l}\text { Magnetostratigraphy and CP nannoplankton } \\
\text { stratigraphy on the same section }\end{array}$ \\
\hline $\begin{array}{l}\text { Van Simaeys et al., } \\
2004\end{array}$ & Belgium & 33 & 22 & 3 & NP nannoplankton stratigraphy on the same sections \\
\hline $\begin{array}{l}\text { Van Simaeys et al., } \\
2005\end{array}$ & Rhine Graben & 33 & 22 & 1 & Magnetostratigraphy on the same section \\
\hline Vellekoop et al., 2015 & Tunisia & 67 & 65 & 3 & $\mathrm{P}$ foraminiferal zones on the same section \\
\hline Versteegh, 1997 & $\begin{array}{l}\text { North Atlantic } \\
\text { Ocean, Italy }\end{array}$ & 3 & 2 & 1 & $\begin{array}{l}\text { Isotope stages, herein recalibrated to } \mathrm{NN} \text { and } \mathrm{CN} \\
\text { nannoplankton zones }\end{array}$ \\
\hline $\begin{array}{ll}\text { Versteegh } & \text { and } \\
\text { Zevenboom, } 1995 & \end{array}$ & South Italy & 28 & 0 & 1 & Magnetostratigraphy on the same section \\
\hline Vieira et al., 2020 & North Sea & 59 & 56 & 3 & NP nannofossil and P foraminifer stratigraphy \\
\hline $\begin{array}{l}\text { Williams and Bujak, } \\
1977\end{array}$ & $\begin{array}{l}\text { Topical and } \\
\text { North Atlantic } \\
\text { Ocean }\end{array}$ & 25 & 0 & 5 & Stages, no independent age control given \\
\hline Williams et al., 1993 & $\begin{array}{l}\text { Northern } \\
\text { Hemisphere }\end{array}$ & 210 & 0 & 5 & Stages, no independent age control given \\
\hline Willumsen, 2012 & New Zealand & 70 & 64 & 3 & P foraminifer stratigraphy \\
\hline Wilpshaar et al., 1996 & Central Italy & 35 & 22 & 3 & $\begin{array}{l}\mathrm{CP} \text { an } \mathrm{NP} \text { nannoplankton and } \mathrm{N} \text { planktonic } \\
\text { foraminifer stratigraphy }\end{array}$ \\
\hline $\begin{array}{l}\text { Woollam and Riding, } \\
1983\end{array}$ & UK & 209 & 140 & 3 & $\begin{array}{l}\text { Boreal ammonite stratigraphy (for conversions see } \\
\text { Supplement 1) }\end{array}$ \\
\hline $\begin{array}{l}\text { Wrenn and Kokinos, } \\
1986\end{array}$ & Gulf Coast & 10 & 0 & 1 & Magnetostratigraphy on the same section \\
\hline $\begin{array}{l}\text { Zegarra and Helenes, } \\
2011\end{array}$ & $\begin{array}{l}\text { Equatorial } \\
\text { Eastern Pacific }\end{array}$ & 18 & 0 & 1 & $\begin{array}{l}\text { Independent age model from magnetostratigraphy, } \\
\text { nannoplankton and foram stratigraphy }\end{array}$ \\
\hline Zevenboom, 1995 & Italy & 26 & 16 & 3 & $\begin{array}{l}\text { NP/NN nannoplankton stratigraphy on the same } \\
\text { sections }\end{array}$ \\
\hline
\end{tabular}


A decision tree is used to determine which papers to include into DINOSTRAT (Fig. 1). This tree first discards studies in which dinoflagellate cysts were the only stratigraphic tool to date the sequence. Although these papers do provide valuable information on stratigraphic order of events, discarding them from this review eliminates the risk of circular reasoning and inherited chronostratigraphic tie. Only those dinocyst events are included that could be calibrated against a stratigraphic tool that can be traced back to the bio-, magneto- or chronozones in the Geologic Time Scale 2012 (GTS2012; Gradstein et al., 2012). The decision tree distinguishes five tiers in these papers (Fig. 1):

- Tier 1 studies present dinocyst events along with magnetostratigraphic constraints obtained from the same sedimentary section. The interpretation of magnetochrons from the paleomagnetic signal was done without the use of dinoflagellate cyst biostratigraphy. Since magnetic reversals are globally synchronous, evaluating the synchroneity of dinocyst events with use of paleomagnetostratigraphy is most robust.

- Tier 2 studies present dinocyst events calibrated along with compromised or problematic magnetostratigraphic constraints on the same sedimentary section, for instance when the inclination signal suffers from a strong overprint, or when the magnetochron assignment is not clear. Studies in which dinocyst events served as biostratigraphic tool for magnetochron assignment are included in this tier as well.

- Tier 3 studies report dinocyst events together with biostratigraphic zones (from nannoplankton, foraminifer or ammonite zones), identified on the same sequence. These studies provide clear report on the identification of these zones in the sequence.

- Tier 4 studies report dinocyst events with biostratigraphy, of which either the derivation is unclear, or the tie to the GTS (e.g., for outdated ammonite zonations), or when biostratigraphic data does not come from the same sequence, but e.g., is interpreted from nearby outcrops.

- Tier 5 studies report dinocyst events with independent chronostratigraphy, of which the derivation is unverifiable, or represents a regional synthesis. 


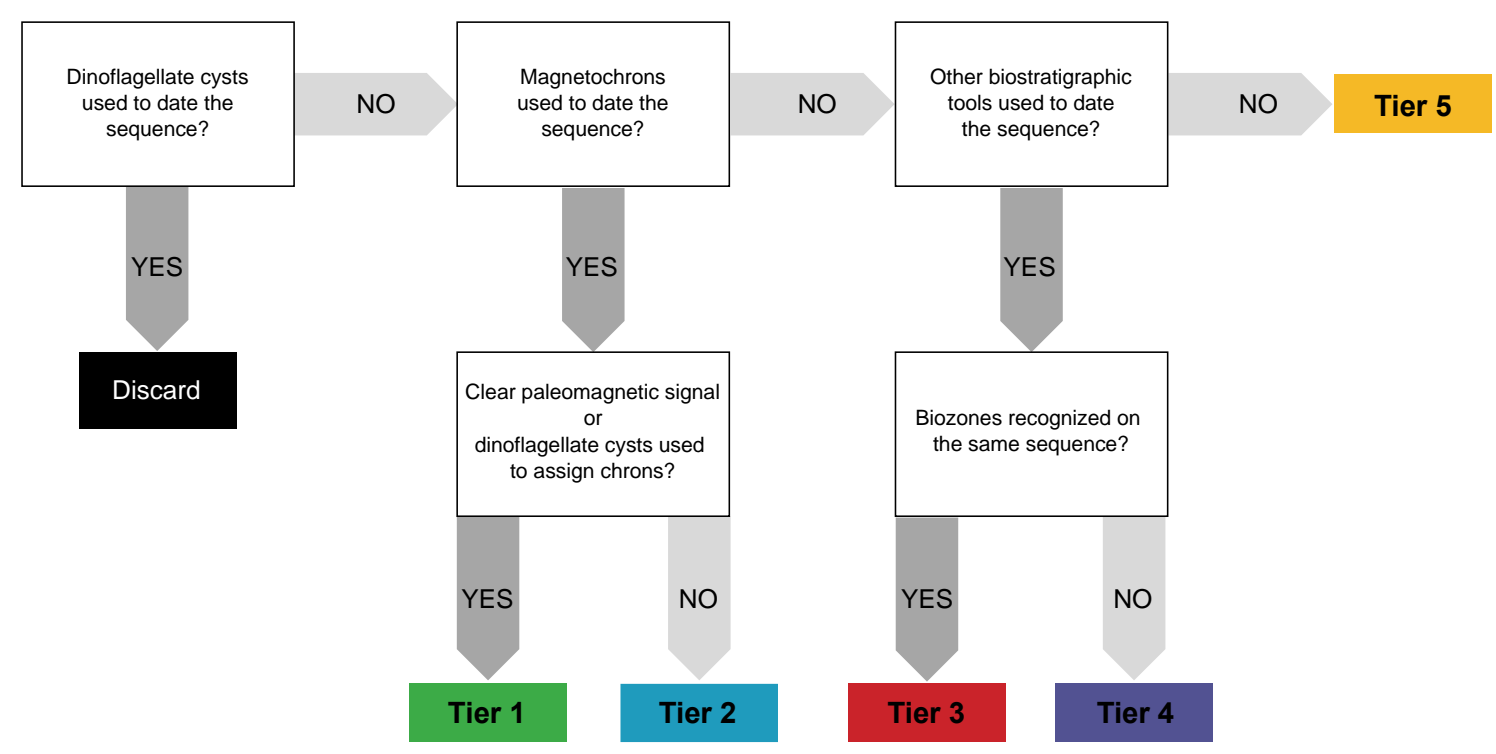

Figure 1: Decision tree for including studies in this review, and categorization criteria for the 5 tiers.

The absolute age of each dinocyst event is not explicitly entered into DINOSTRAT. Rather, its position within the zone it was calibrated to is entered. Ages are subsequently calculated via linear interpolation between these tie points, as follows:

in which [\#\#]\% is linearly interpolated between base (0\%) and top (100\%) of tie points, [stratigraphic tool] is the bio-, magneto or chronozonation in the GTS2012, and [zone] is the name of the zone, chron or stage in which the dinocyst event falls. The rationale behind this approach instead of simple entry of the age is that while the absolute ages of dinocyst events are dependent on the evolving knowledge of the chronostratigraphic time scale, the stratigraphic position of the event relative to the tie points in the record is fixed. This approach makes it easier to update the ages of the dinocyst events when the ages of the chrono-, magneto- and biozones are updated in the future. If dinocyst events fall between two different stratigraphic ties, the event is noted as follows:

$[\mathrm{FO} / \mathrm{LO}]$ of $[$ Genus, Species $]=[\# \#] \%$ between $[\# \#] \%$ in $[$ stratigraphic tool $] \$[$ zone $]$ and $[\# \#] \%$ in $[$ stratigraphic tool] $\$[$ zone $]$

Outdated Jurassic and Cretaceous ammonite zonation schemes are converted to those presented in the GTS2012 (see Supplement 1; following Ogg and Hinnov, 2012a, $\mathrm{b}$ and citations therein). FOs in the bottom of sections, and LOs at the top 
150 of sections are systematically omitted, unless they were specifically indicated to represent an FO or LO. Younger publications presenting calibrations of dinocyst species from the same section overwrite older publications. Modern dinoflagellate cyst species and their latitudes (from Marret et al., 2020, and Mertens et al., 2014 for Dapsilidinium pastielsii) are entered with an LO of $0 \mathrm{Ma}$ (modernst.csv in Bijl, 2021 for surface sediment station locations, modernsp.csv in Bijl, 2021 for dinoflagellate cyst species at those stations).

Each event entry in DINOSTRAT (Dinoevents_Jan2021.csv in Bijl, 2021) includes the (paleo-) latitude of that event. This is interpolated using the age of the event and its location, which has a paleolatitude evolution through time (Paleolatitude.csv in Bijl, 2021; with use of Paleolatitude.org; Van Hinsbergen et al., 2015). Paleolatitudes of sites in mobile orogenic belts are interpolated using regional tectonic reconstructions, and as such are prone to additional latitudinal uncertainty.
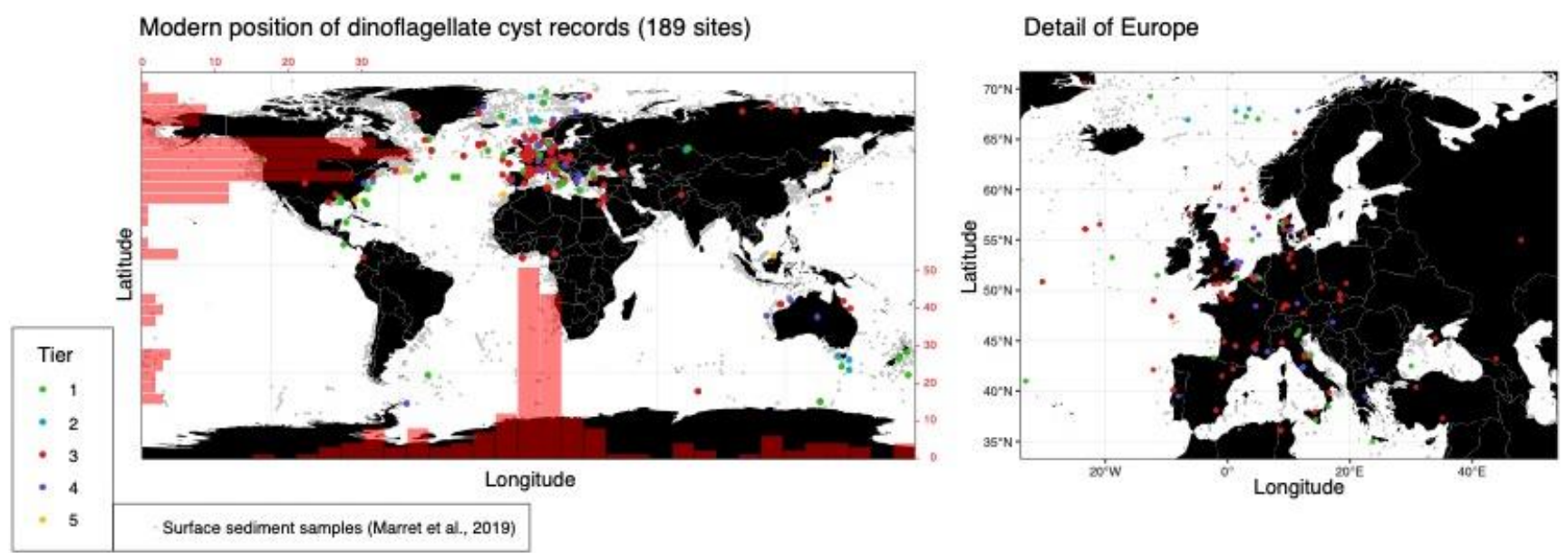

Figure 2: Present-day geographic distribution of sedimentary sequences used in this study (colors of the dots correspond to the tier these sites belong in), and surface sediment stations (in grey dots; Marret et al., 2020 and Mertens et al., 2014). A. Global. B. Detailed map of sites in Europe.

\section{The database}

\subsection{Sites}

DINOSTRAT currently contains dinocyst events from 199 publications and 189 sites. The wider North Atlantic/European area is strongly overrepresented (Fig. 2). Few sites are from the Pacific Ocean, southern Atlantic and Indian Ocean, and the equatorial region. Probably this reflects a genuine bias in the available information, because of focus of the community towards 
170 economically interesting regions (e.g., for hydrocarbon industry). It may also in part reflect a bias towards 'western society' research, and poor accessibility of publications from non-western societies.

The paleolatitudinal position of the sites through time confirms the strong overrepresentation of Northern Hemisphere midlatitude sections (Fig. 3), and underrepresentation of the tropical regions, Pacific Ocean and southern mid-latitudes. The Paleogene has the largest latitudinal spread of records, better yet than the Neogene. Particularly the Mesozoic has few entries

175 from the Southern Hemisphere and equatorial regions. The Mesozoic records are predominantly calibrated to ammonite stratigraphy (Tier 3 and 4), and in some occasions to magnetostratigraphy (Tier 1 and 2; Fig. 3). Ammonite zones presented in the papers often had to be converted to those in the GTS2012, which is not always straightforward, as the zone definitions have changed through time (Ogg and Hinnov, 2012a, b). The ammonite zonations are prone to regional diachroniety themselves, which was demonstrated particularly for the late Jurassic (Ogg and Hinnov, 2012b). This may create a level of

180 circular reasoning when dinocyst events are calibrated against these zones, because diachronous dinocyst events in DINOSTRAT may be the result of diachronous ammonite zones rather than diachronous dinocyst events.

\subsection{Calibrated dinocyst events}

DINOSTRAT version 1.0 includes over 8500 entries of calibrated dinoflagellate cyst events (excluding the modern dinocyst database). On a species level, originations in DINOSTRAT peak in the Middle Jurassic (Bajocian-Callovian) the lower

185 Cretaceous (upper Valanginian-Barremian) and the Eocene (Ypresian; Fig. 3b). Extinctions peak in the lower Cretaceous (Berriasian-Barremian), upper Cretaceous (Maastrichtian), Oligocene (Rupelian) and Miocene (Serravalian; Fig. 3b). This pattern is generally followed on a genus level, which likely has a stronger relation to the biologic diversity than dinocyst species diversity (Fensome et al., 1993).

The interpolated paleolatitudes for dinoflagellate cyst events in DINOSTRAT allows detailed evaluation of the latitudinal

190 synchroneity of dinocyst events. This paper presents a selection of the data in DINOSTRAT, focusing on the stratigraphic and geographic range of modern dinocyst species, of dinocyst families/subfamilies and of a selection of quasi-synchronous dinocyst events. Users can filter DINOSTRAT per locality (to present the stratigraphic order of events per site) and/or per taxon (to see the geographic variability of the range of any taxon), to serve their purposes. 
https://doi.org/10.5194/essd-2021-158

Preprint. Discussion started: 8 July 2021

(c) Author(s) 2021. CC BY 4.0 License.

(c) (1)

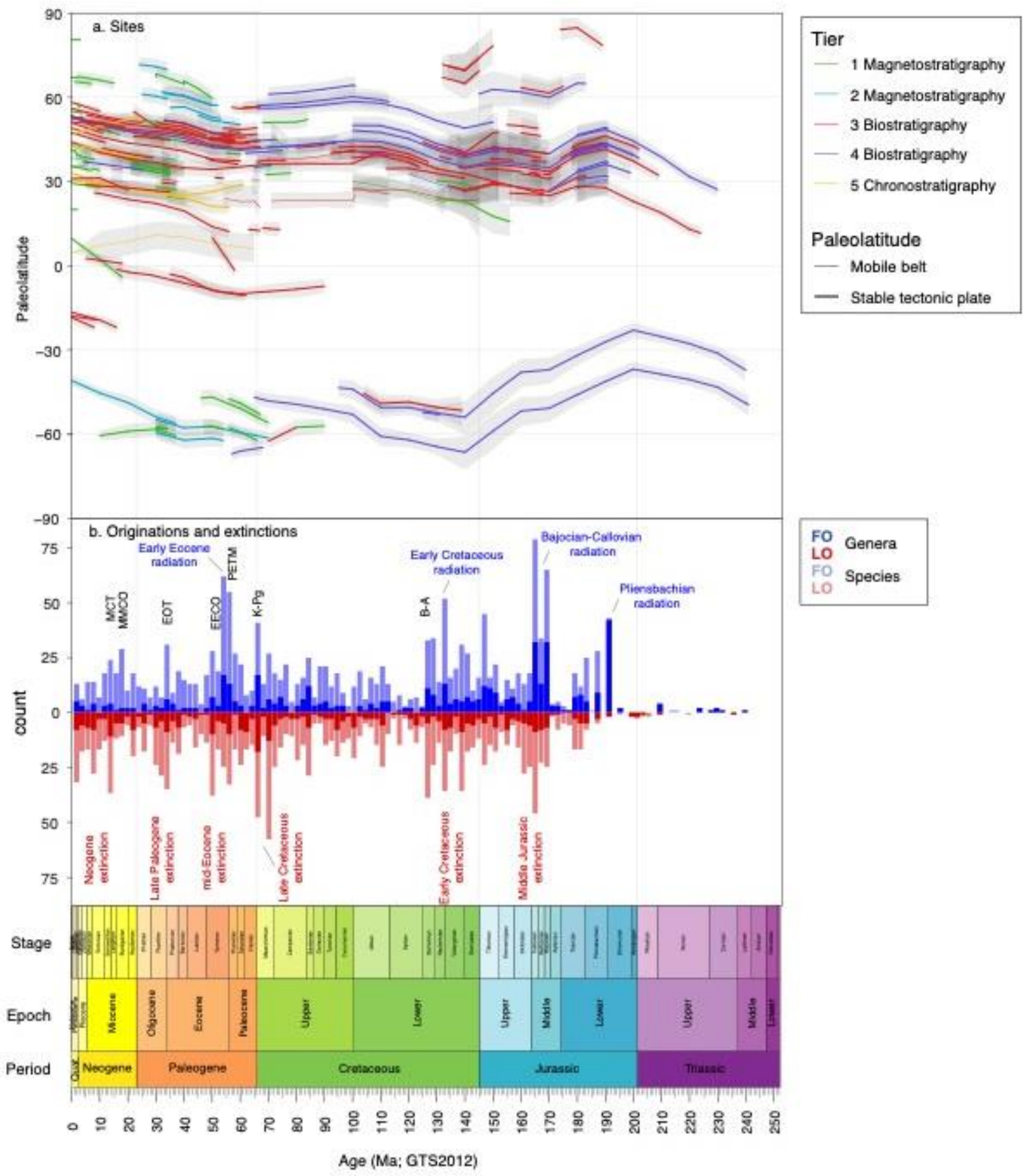

Figure 3: Data in DINOSTRAT. a. Paleolatitude and age span of sites used in DINOSTRAT. Colors corresponds to tier, line thickness separates sites on stable oceanic or continental plates from those in mobile orogenic belts. Grey 
https://doi.org/10.5194/essd-2021-158

Preprint. Discussion started: 8 July 2021

(c) Author(s) 2021. CC BY 4.0 License.

(c) (i)

envelopes represent the error of the paleolatitude reconstruction inherited from the paleomagnetic reference frame (see Van Hinsbergen et al., 2015). b. Dinocyst events in DINOSTRAT, filtered for oldest FOs (blue) and youngest LOs (red) of dinocyst species (lighter shade) and genera (darker shade), in 2 Myr bins. Several phases of climateenvironmental change are highlighted in black: Barremain Aptian boundary (B-A), Cretaceous-Paleogene boundary (K-Pg), Paleocene-Eocene Boundary (PETM), Early Eocene Climatic Optimum (EECO), Eocene-Oligocene transition (EOT), mid-Miocene Climatic Optimum (MMCO), Miocene climatic transition (MCT). Extinction and radiation phases in dinocysts are highlighted in red and blue text, respectively.

\subsubsection{The stratigraphic range of modern dinoflagellate cyst species}

Modern dinoflagellate cysts from surface sediment samples (Marret et al., 2020, $\mathrm{n}=3600$ and Mertens et al., 2014, $\mathrm{n}=5$ ) have a species-specific latitudinal spread. Sea surface temperature and nutrient conditions are the main controlling factors on modern assemblage compositions (Zonneveld et al., 2013). The database presented here allows comparison of modern latitudinal spread of these species to that of the past, and their age and latitude of oldest first occurrence (Supplement 2, and a selection in Fig. 4). Most modern species that have entries in DINOSTRAT have originations in the mid-Cenozoic: Impagidinium species, Operculodinium centrocarpum, Tectatodinium pellitum, Tuberculodinium vancampoae (Fig. 4). Lingulodinium machaerophorum has a first occurrence around $60 \mathrm{Ma}$. The exception is Spiniferites ramosus, a generalist species with a robust morphology through time, that has a remarkably consistent FO in the Berriasian ( $145 \mathrm{Ma}$; Fig. 4). The dinocyst species that have geographic distributions restricted to one hemisphere today were also latitudinally restricted in the geologic past (e.g., Spiniferites elongatus, Trinovantedinium variabile; Fig. 4). Achomosphaera andalousiensis, Dapsilidinium pastielsii, Impagidinium velorum, Melitasphaeridium choanophorum, Tectatodinium pellitum, Tuberculodinium vancampoae had wider latitudinal distributions until the recent past, on both hemispheres. Melitasphaeridium choanophorum had progressively older LOs north and south of its restricted modern latitudinal distribution in northern mid-latitudes. Lingulodinium machaerophorum and Polysphaeridium zoharyi had a higher paleolatitudinal occurrence on only one hemisphere. Several modern taxa (e.g., Bitectatodinium spongium, Polykrikos spp., Protoperidinium spp., Echinidinium spp., most Islandinium species, most Stelladinium species, Polarella glacialis) have no entry yet in DINOSTRAT. This could be because some species concepts are relatively novel, or have poor preservation potential in the fossil record (e.g., because of selective degradation; Zonneveld et al., 2010). 
https://doi.org/10.5194/essd-2021-158

Preprint. Discussion started: 8 July 2021

(c) Author(s) 2021. CC BY 4.0 License.
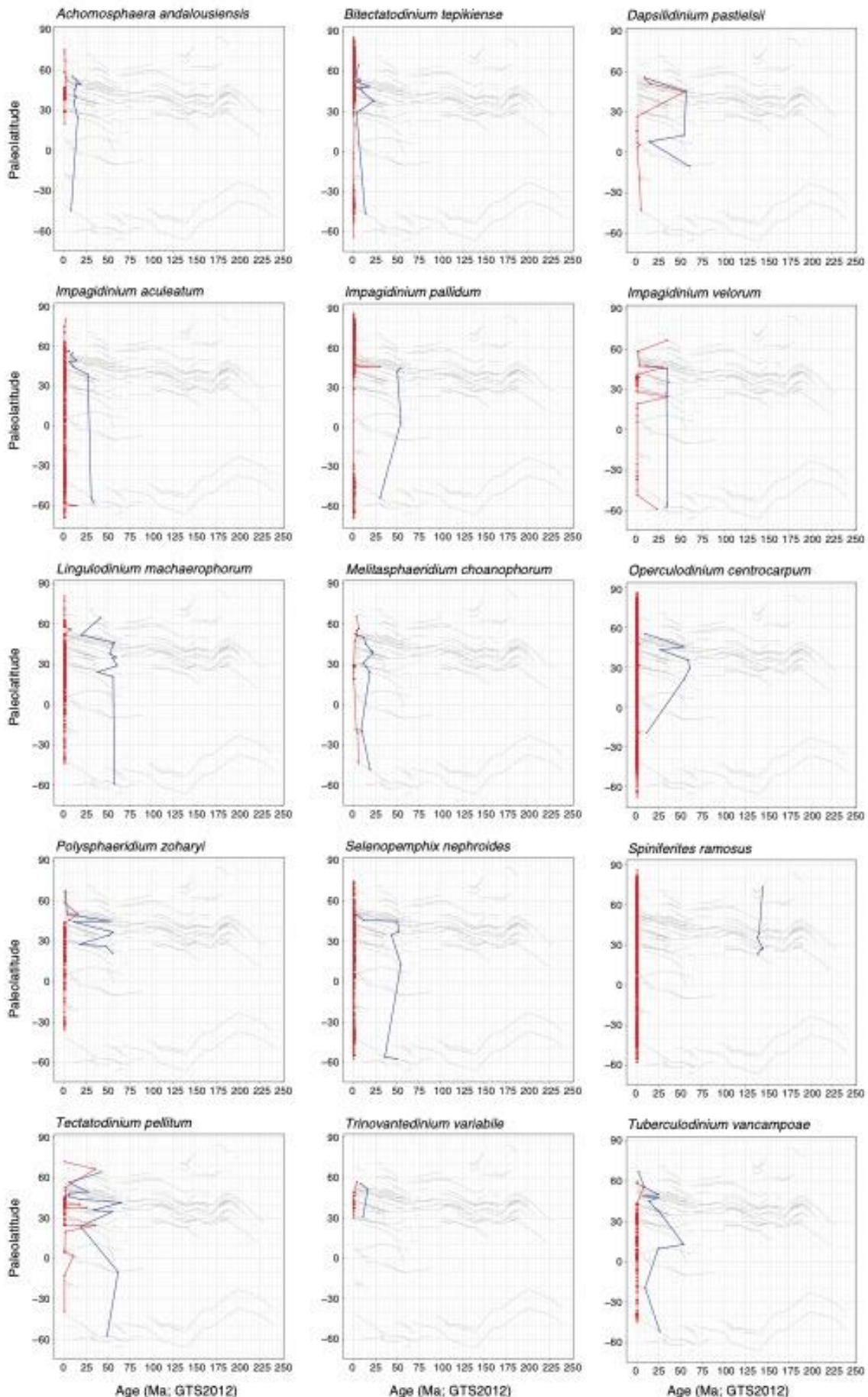
Figure 4: Age and paleolatitude of first (in blue) and last (in red) occurrences of selected modern dinoflagellate cyst species. Last occurrences come from both the surface sediment database (Marret et al., 2020, with Mertens et al., 2014) and entries in DINOSTRAT.

\subsubsection{Dinocyst (sub-) families}

230 Range charts of the Sites in DINOSTRAT are provided in the Supplements (see "Sites" folder in Supplement 2). The age over paleolatitude entry in DINOSTRAT allows evaluation of the latitudinal difference in event ages for each individual species in DINOSTRAT ( $n=1914)$, as well as for groupings per genus $(n=460)$ and family $(n=28)$ (Supplement 2). Users can produce/adapt these plots themselves with help of the R markdown script "plot creator.Rmd" in Bijl, 2021). The most robust dinocyst events will have synchronous ages of FOs and LOs per paleolatitude (i.e., vertical blue and red lines in the plots of

235 Supplement 2). The FOs and LOs connected per species and grouped in (sub)families are plotted and described below, with particularly synchronous taxa highlighted. The purpose of these plots is threefold: First, they show the total stratigraphic range and latitudinal spread of these dinoflagellate (sub)families, and time intervals when and where phases of strong diversification and extinction occur in that (sub)family. Second, as with the plots of modern species, they show in which paleolatitudes these supra-generic groups first appear, but also where they last go extinct. Although earlier compilations of the evolution of dinocyst

240 families do exist (e.g., McRae et al., 1996), DINOSTRAT presents the fundamental spatio-temporal observations that underpin these compilations. Thirdly, the plots allow presentation of the database in a way that the validity of extrapolating dinoflagellate cyst events on a supra-regional scale can be critically evaluated in the discussion.

Order Gonyaulacales

245 Family Areoligeraceae (Fig. 5)

Range: The Areoligeraceae range from the Bathonian ( 168 Ma, FOs of Adnatosphaeridium spp. and Senoniasphaera spp.) to the mid-Miocene ( 18 Ma, LO of Chiropteridium galea). Areoligeraceae seem to range longer in Northern Hemisphere mid-latitudes (FO $\sim 169 \mathrm{Ma}$; LO $\sim 18 \mathrm{Ma}$ ) than in the rest of the world (FO 145 Ma; LO 36Ma), although this can be in part related to a sampling bias. The oldest FOs in $\mathrm{NH}$ mid-latitudes are species with a stratigraphic occurrence restricted to that 250 area.

Quasi-synchronous events: Events of species of Areoligera, Chiropteridium, Glaphyrocysta, Palynodinium, Schematophora and Senoniasphaera, particularly in the late Cretaceous and Paleogene (Fig. 5). Many taxa in this subfamily however show strongly diachronous events between hemispheres. 


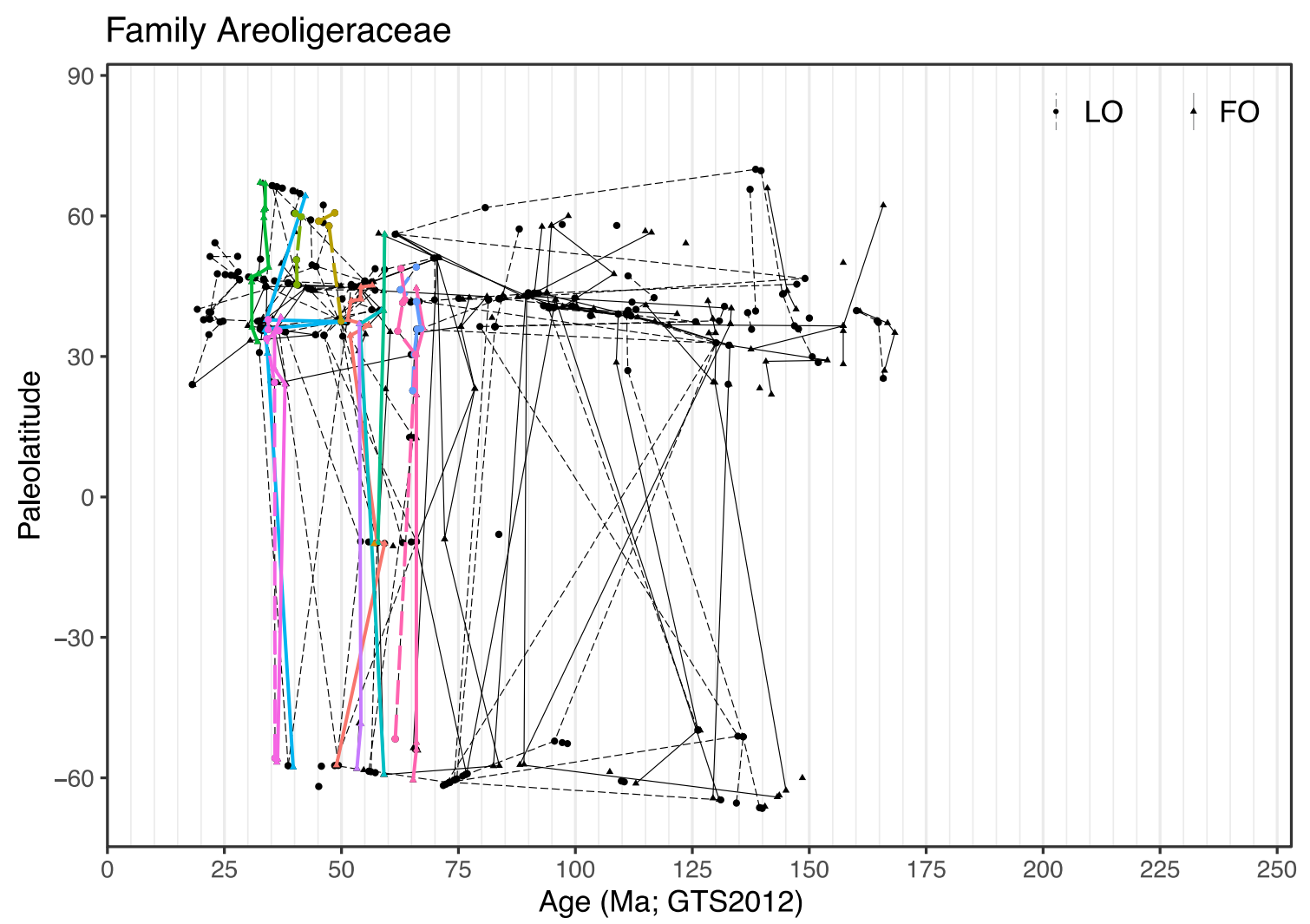

Adnatosphaeridium vittanum Areoligera gippingensis Areoligera medusettiformis

\section{Areoligera tauloma Chiropteridium lobospinosum Glaphyrocysta divaricata}

Glaphyrocysta pastielsii Glaphyrocysta semitecta Palynodinium grallator
Schematophora obscura Schematophora speciosa Senoniasphaera inornata

Figure 5: Ages and paleolatitudes of first (solid line and triangles) and last (dashed line and circles) occurrences of dinocyst species of the Family Areoligeraceae. Solid and dashed lines connect first and last occurrences, respectively, for each species, between sites. Colored lines represent quasi-synchronous species events.

Family Ceratiaceae (Fig. 6)

Range: The Ceratiaceae first appear in the Tithonian ( 152Ma, FO of Muderongia simplex) in NH mid-latitudes, represents a diverse group in the early Cretaceous and has an LO in the latest Cretaceous ( $66 \mathrm{Ma}, \mathrm{LO}$ of Odontochitina operculata). Quasi-synchronous events: LO Odontochitina costata, LO Phoberocysta neocomica, range of Pseudoceratium pelliferum (Fig. $6)$. 


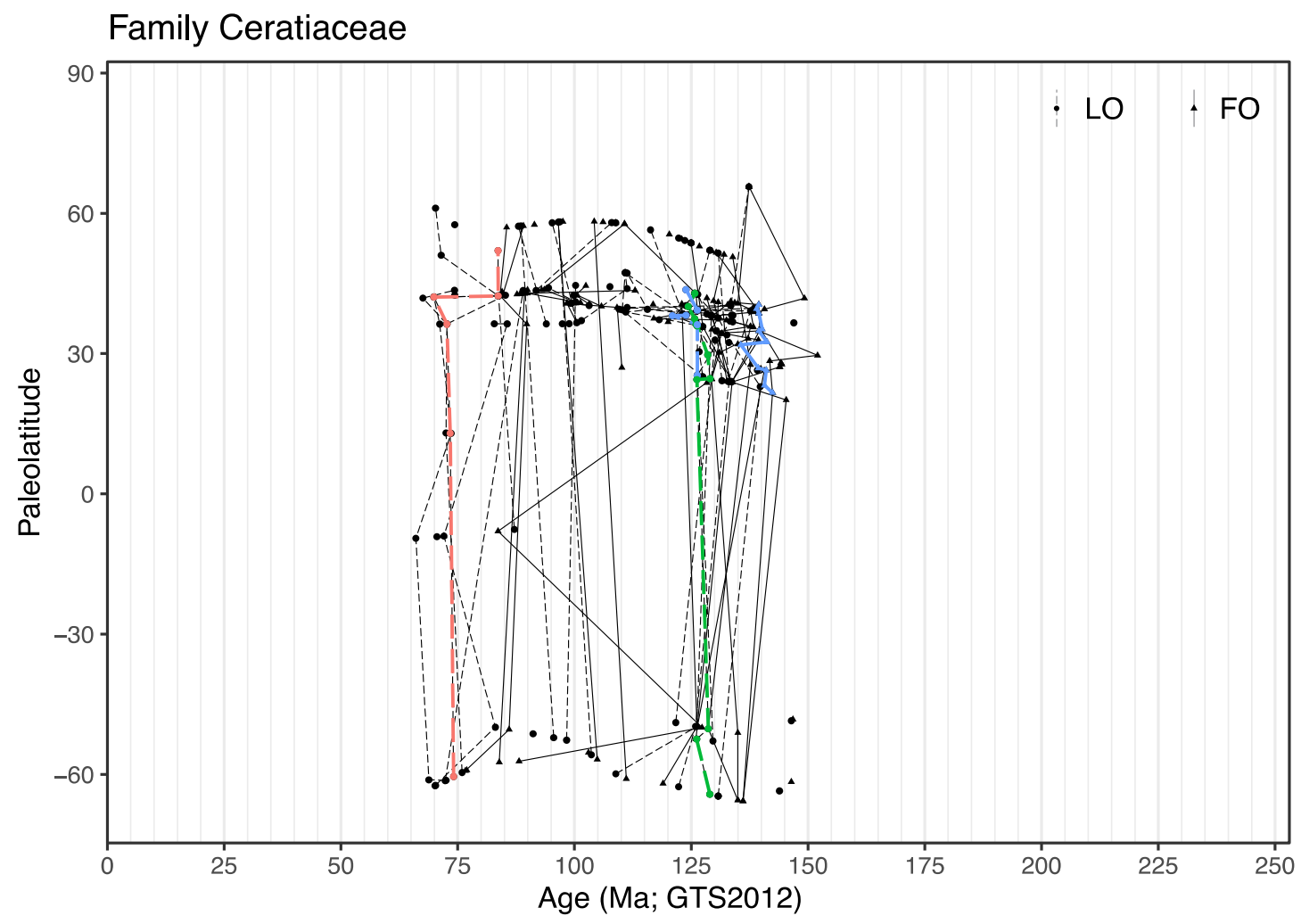

Odontochitina costata Phoberocysta neocomica Pseudoceratium pelliferum

Figure 6: As Figure 5, but for the Family Ceratiaceae.

Family Cladopyxiaceae (Fig. 7)

Range: This family first appears in the Pliensbachian ( 188Ma, FO of Freboldinium spp.), and ranges until the late Oligocene ( 25 Ma; Licracysta semicirculata).

Quasi-synchronous events: Several species of Enneadocysta. LO of Fibradinium annetorpense around 60 Ma and the LO of Licracysta semicirculata around 26 Ma Most entries in the late Cretaceous and Paleogene are highly diachronous. 


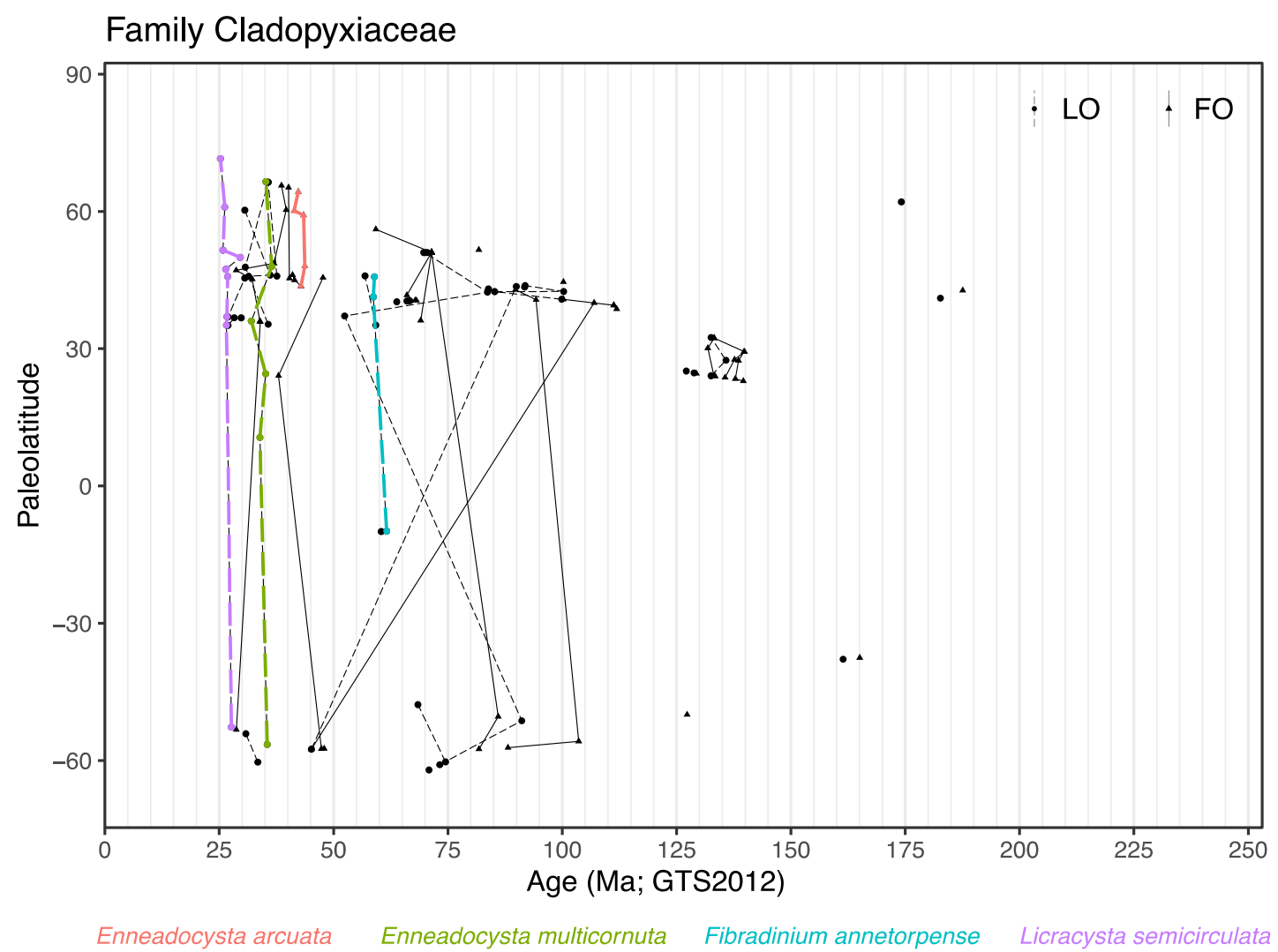

Figure 7: As Figure 5, but for the Family Cladopyxiaceae.

Family Goniodomaceae (Fig. 8)

Range: Goniodomaceae first appear in the mid-Tithonian ( 150 Ma, FO of Hystrichosphaeridium petilum) in the NH midlatitudes, most entries are from the Paleogene, and continue with modern species Polysphaeridium zoharyi and Tuberculodinium vancampoae. Quasi-synchronous events: Species of Alisocysta, Eisenackia, Heteraulacacysta and Homotryblium. Many species ranges in this family are notably diachronous. Although some species do seem to show similar event ages between southern high latitudes and northern mid-latitudes (Fig. 8), those with multiple entries in the northern midlatitudes, where site density is highest, show strong diachroneity over short latitudinal distances. Modern species have a 285 restricted latitudinal spread to subtropical and tropical regions, but not too long into the geologic past, species of this family exhibited much wider latitudinal ranges $\left(65^{\circ} \mathrm{S}-70^{\circ} \mathrm{N}\right)$. 


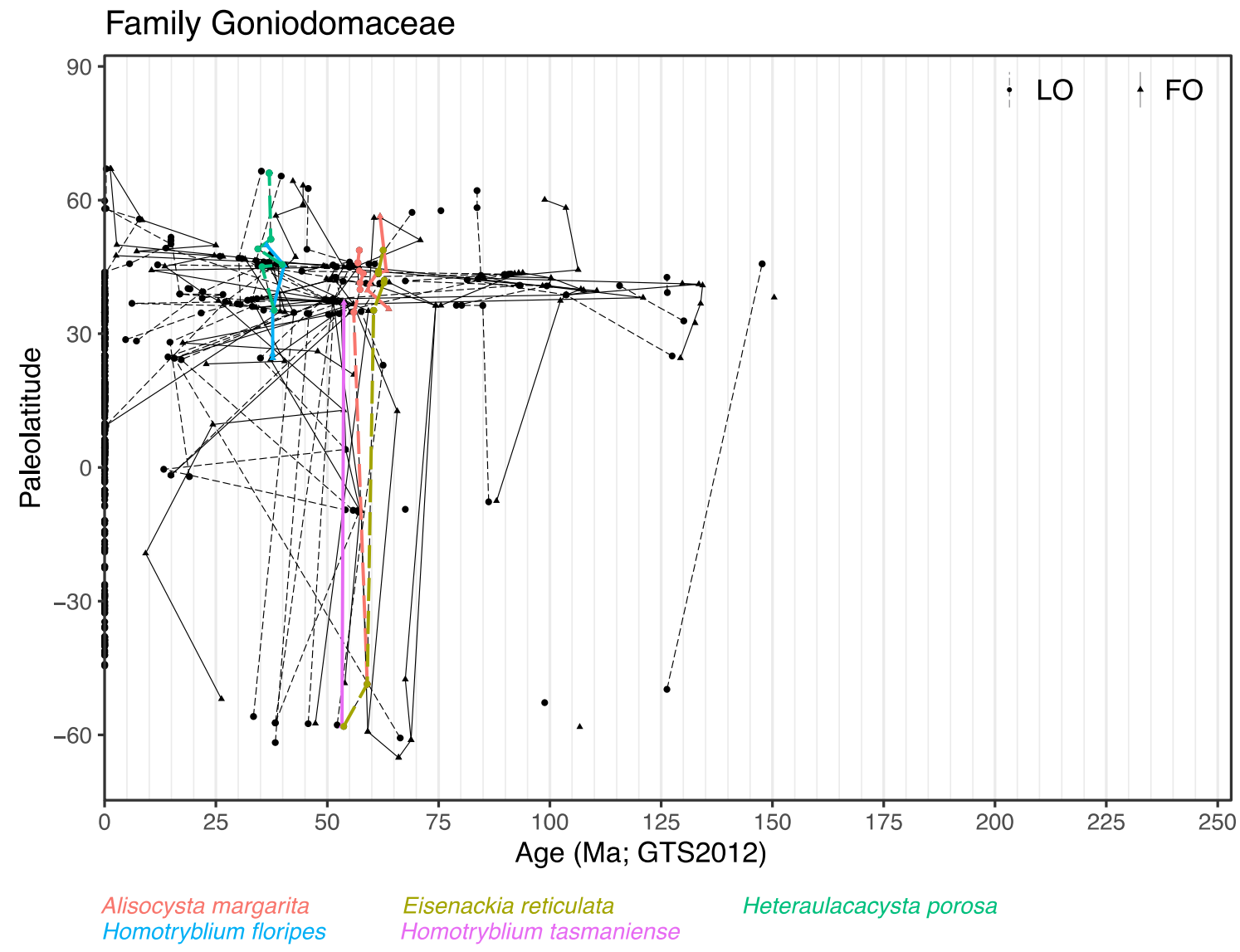

Figure 8: As Figure 5, but for the Family Goniodomaceae.

Family Gonyaulacaceae

Subfamily Cribroperidinioideae (Fig. 9)

Range: This subfamily includes the extant species Operculodinium centrocarpum and Lingulodinium machaerophorum. The subfamily first appears in NH mid-latitudes in the Aalenian ( 172 Ma) with Kallosphaeridium spp. and in the Bajocian ( 169Ma) with Cribroperidinium spp., and shortly thereafter Aldorfia and Korystocysta. Cribroperidinium is a long-ranging genus. Many entries are from the early Cretaceous ( 125 Ma) and early Paleogene (66-34 Ma)

Quasi-synchronous events: Several species of Cordosphaeridium and Danea, and species of Aldorfia, Apteodinium, Carpatella, Cooksonidinium, Diphyes, Hystrichokolpoma and Operculodinium. The subfamily has many entries in the Paleogene, but many of these events are not synchronous latitudinally. 


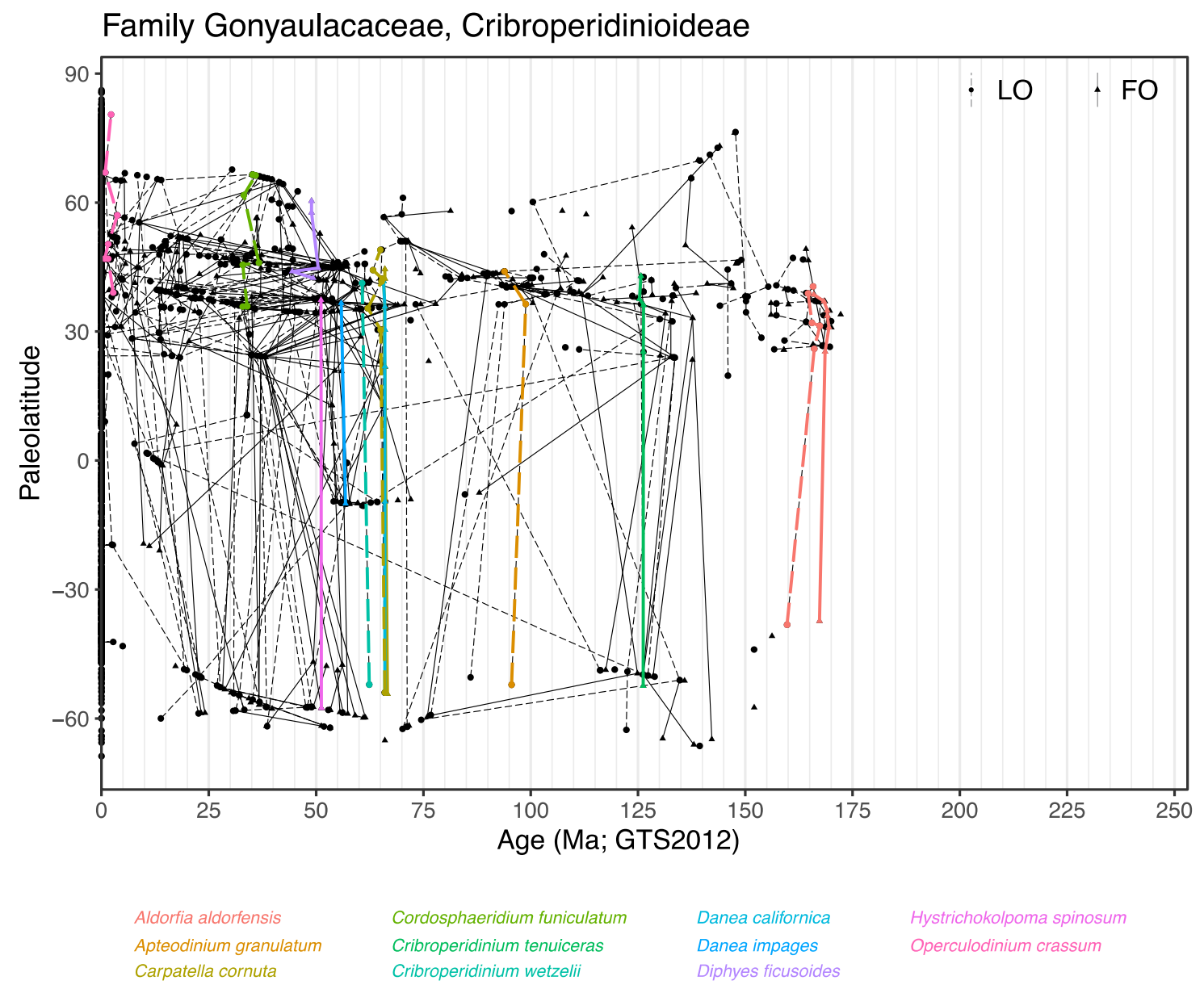

Figure 9: As Figure 5, but for the Family Gonyaulacoideae, subfamily Cribroperidinioideae.

Subfamily Gonyaulacoideae (Fig. 10)

Range: The subfamily of Gonyaulacoideae includes common modern cyst genera such as Spiniferites spp., Achomosphaera spp., Impagidinium spp., Nematosphaeropsis spp. and Tectatodinium spp. The subfamily first occurs in the Bajocian $(\sim 170$ Ma), with the FO of Gonyaulacysta spp. and Tubotuberella spp.

Quasi-synchronous events: species of Achomosphaera, Ataxiodinium, Callaiosphaeridium, Corrudinium, Ectosphaeropsis Hystrichodinium, Impagidinium, Spiniferites and Unipontidinium (Fig. 10). Events of species of Escharisphaeridia spp.,

310 Gonyaulacysta spp., and Tubotuberella spp., range slightly longer in Northern Hemisphere high latitudes than in mid-latitudes. Many species in this subfamily are strongly diachronous. 


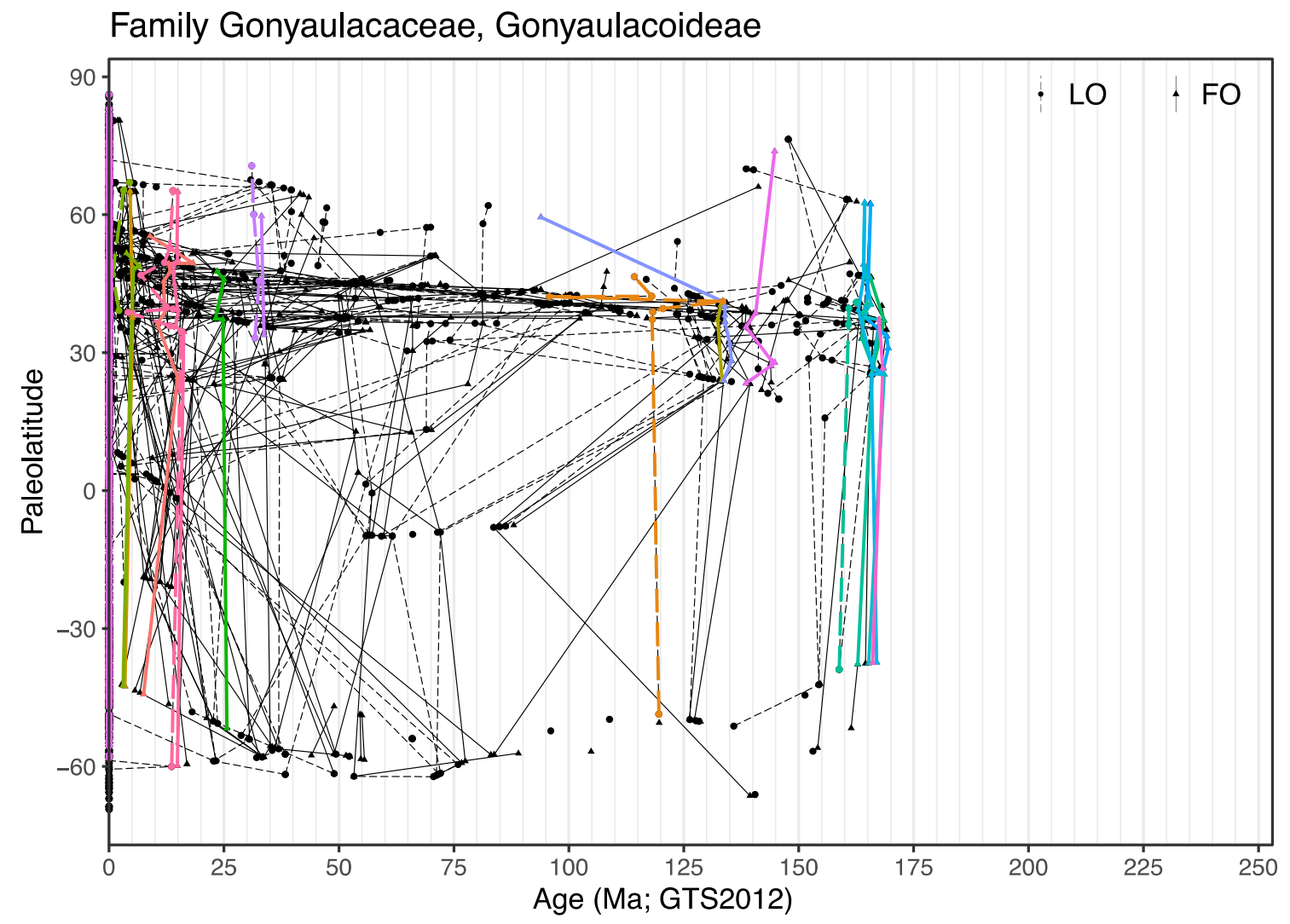

Achomosphaera andalousiensis Achomosphaera neptuni

Ataxiodinium confusum

Callaiosphaeridium trycherium
Corrudinium harlandii Ectosphaeropsis burdigalensis Escharisphaeridia pocockii Gonyaulacysta centriconnata
Gonyaulacysta eisenackii
Gonyaulacysta jurassica
Gonyaulacysta pectinigera

Spiniferites manumit Spiniferites ramosus Tubotuberella dangeardii Unipontidinium aquaeductum

Figure 10: As Figure 5, but for the Family Gonyaulacaceae, subfamily Gonyaulacoideae.

Subfamily Leptodinioideae (Fig. 11)

Range: The Leptodinioideae first appear in the Aalenian ( 172 Ma, FO of Meiourogonyaulax valensii), and includes many species events in the Bajocian and Bathonian. Although most entries are in the Jurassic and lower Cretaceous, the subfamily ranges into the late Miocene ( 8 Ma, LO of Acanthaulax miocenica).

Quasi-synchronous events: Events in species of Ambonosphaera, Areosphaeridium (NH), Cooksonidium, Ctenidodinium, Dichadogonyaulax, Endoscrinium, Herendeenia, Kleithriasphaeridium, Leptodinium, Limbodinium, Litosphaeridium, Rigaudella aemula, Sirmiodiniopsis, Stiphrosphaeridium and Wanaea. 


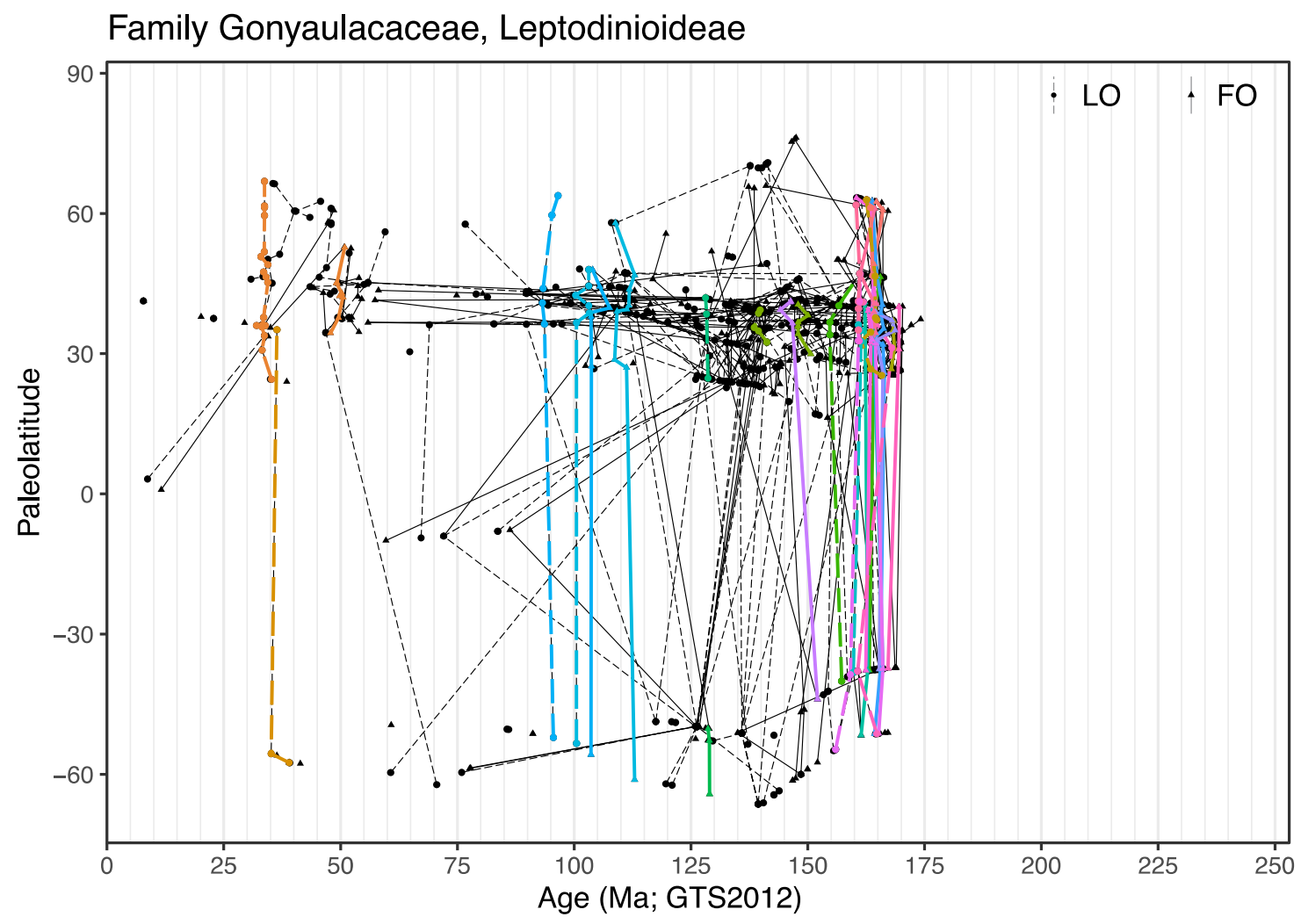

Ambonosphaera calloviana Areosphaeridium diktyoplokum Cooksonidium capricornum Ctenidodinium continuum Ctenidodinium cornigera Dichadogonyaulax culmula Endoscrinium galeritum
Herendeenia postprojecta Kleithriasphaeridium corrugatum Leptodinium ambiguum

Limbodinium absidatum Litosphaeridium arundum Litosphaeridium siphoniphorum Rigaudella aemula
Sirmiodiniopsis orbis

Stiphrosphaeridium dictyophorum Wanaea digitata

Wanaea fimbriata

Wanaea indotata

Wanaea thysanota

Figure 11: As Figure 5, but for the Family Gonyaulacoideae, subfamily Leptodinioideae.

Other (Fig. 12)

Remarks: Other species in the Family Gonyaulacaceae could not be assigned to a subfamily. Species of Barbatacysta, Chytroeisphaeridia, Glossodinium, Hemiplacophora, Nelchinopsis, Saturnodinium, Scriniodinium, Sepispinula,

Stephodinium, Trichodinium spp. have remarkably consistent events. 


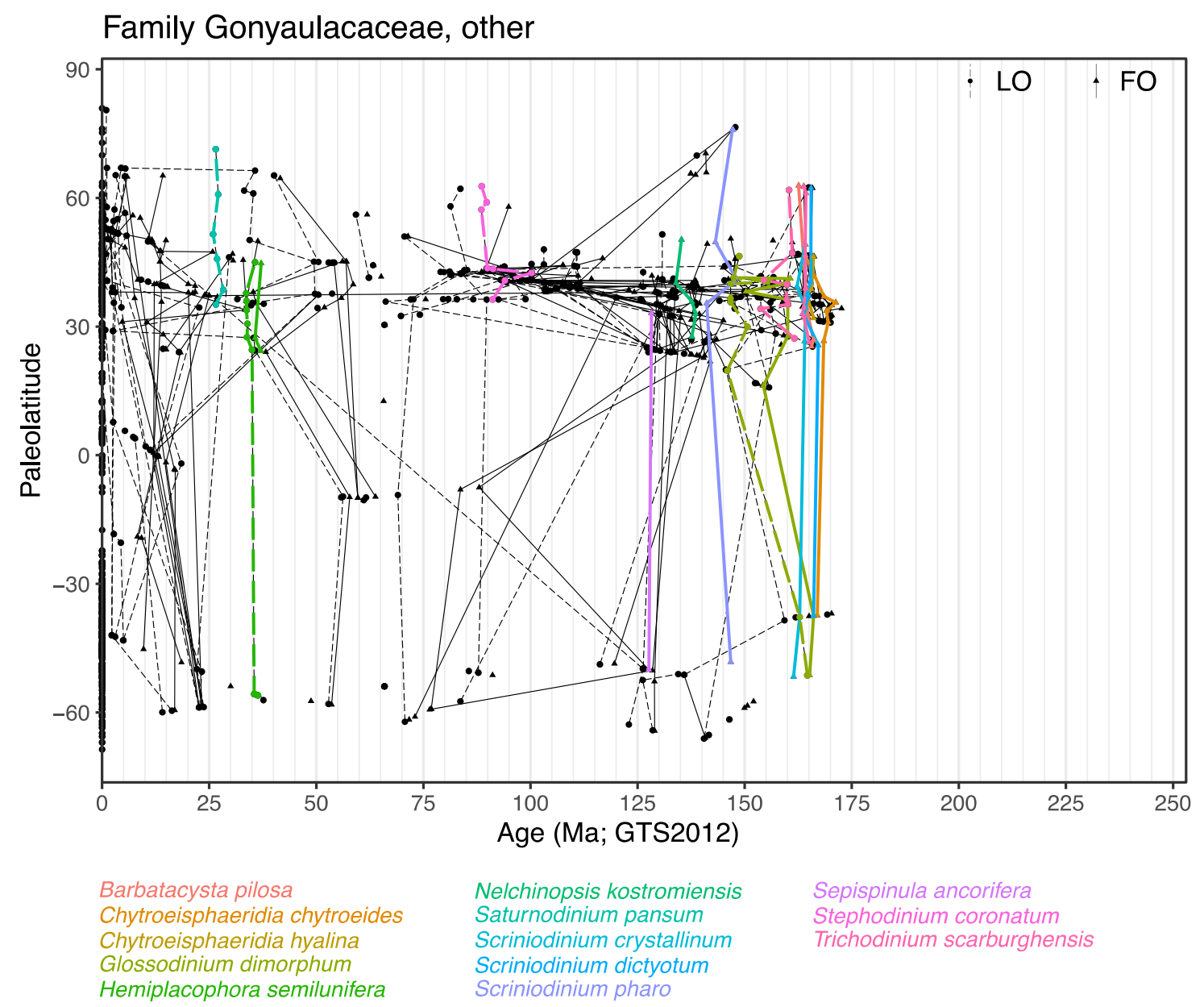

Figure 12: As Figure 5, but for other genera in the Family Gonyaulacoideae.

335 Family Mancodiniaceae (Fig. 13)

Range: Species of Mancodiniaceae occur in sediments from the late Sinemurian ( 190 Ma) to the mid-Bathonian ( 167 Ma) and seem quasi-synchronous latitudinally. 


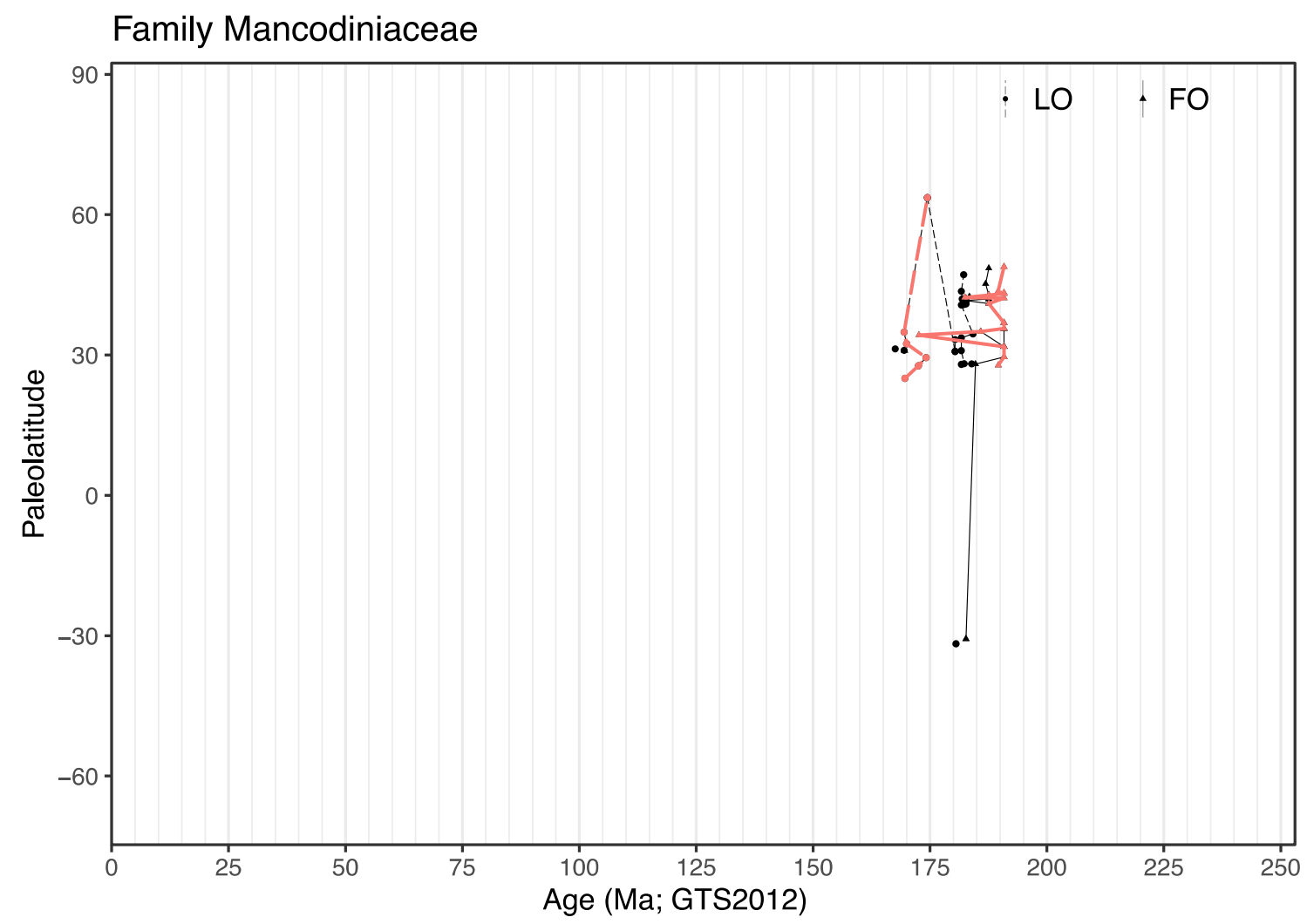

Mancodinium semitabulatum

Figure 13: As Figure 5, but for the Family Mancodiniaceae.

Family Pareodiniaceae (Fig. 14)

Range: Pareodiniaceae first appear in the late Toarcian ( 176 Ma, FO of Pareodinia halosa) and range in northern hemisphere mid-latitudes into the Cenomanian ( 95 Ma, LO of Batioladinium jaegeri). Events of species in Carpathodinium, Pareodinia 345 (both NH only), Aprobolocysta and Batioladinium appear quasi-synchronous. 
https://doi.org/10.5194/essd-2021-158

Preprint. Discussion started: 8 July 2021

(c) Author(s) 2021. CC BY 4.0 License.

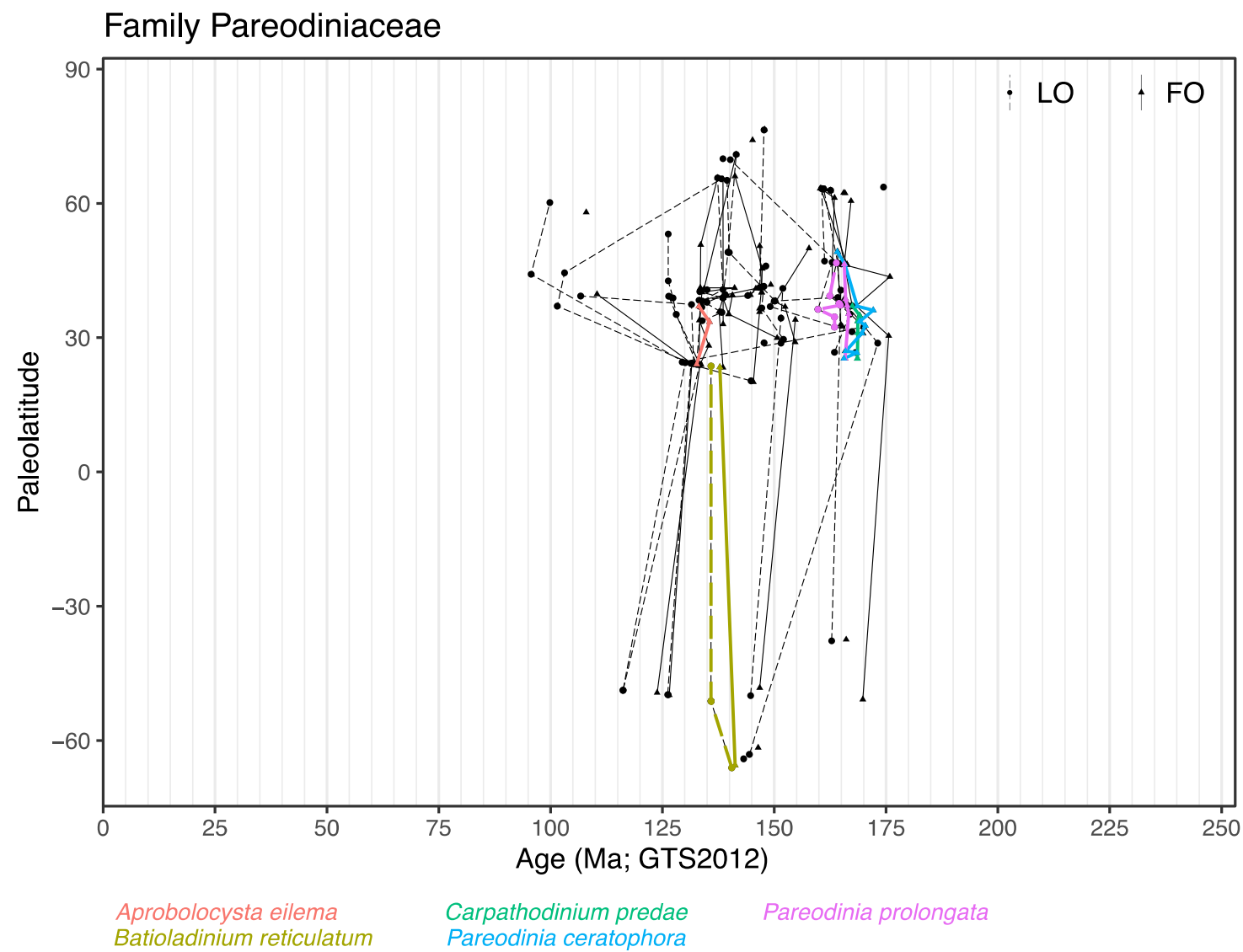

Figure 14: As Figure 5, but for the Family Pareodiniaceae.

350 Family Scriniocassiaceae (Fig. 15)

Range: Scriniocassiaceae range from the Pliensbachian ( 187 Ma, FO of Scriniocassis weberi) to the Bajocian ( 169Ma, LO of Scriniocassis weberi) and comprise of only 3 species. Events from this family are only reported from the Northern Hemisphere. 


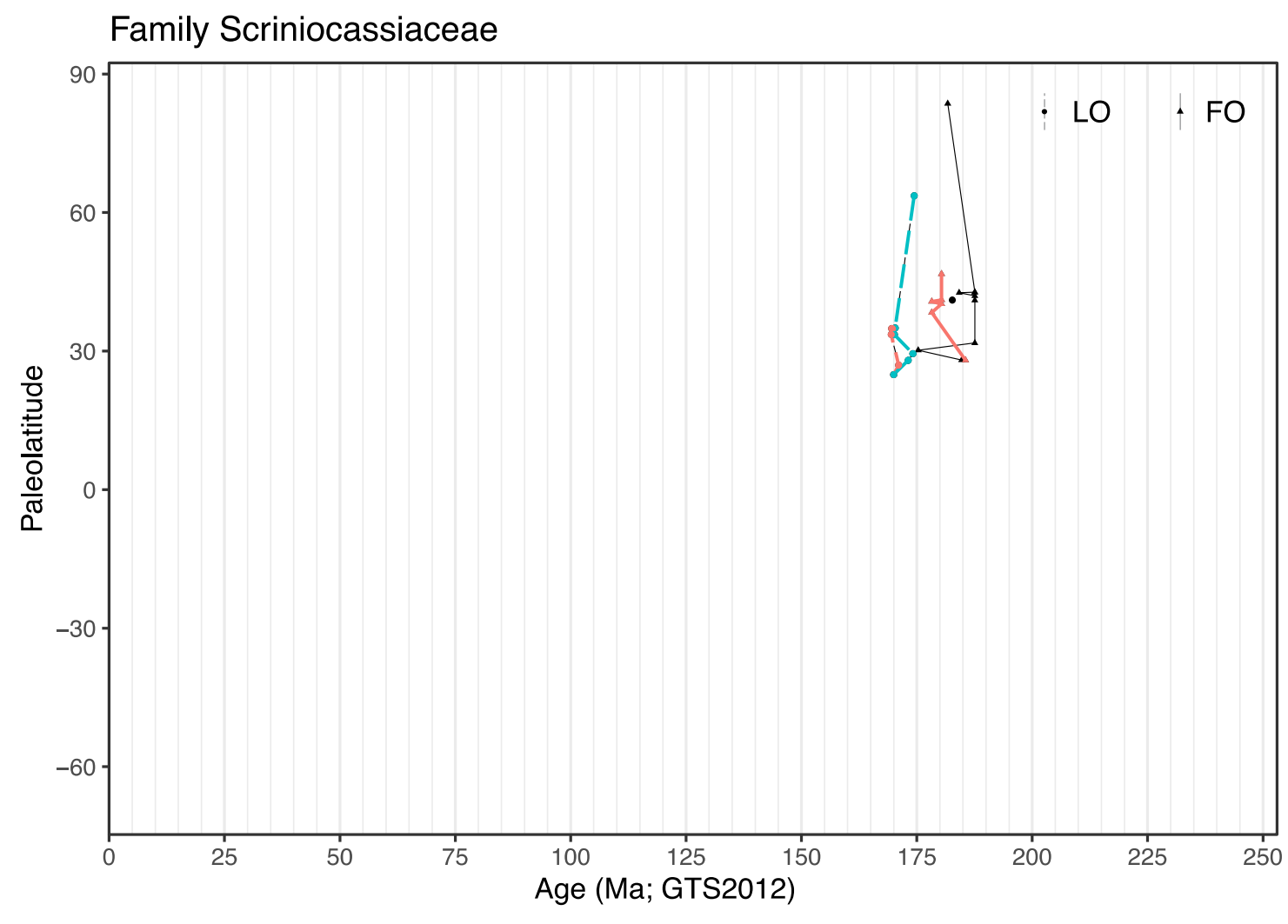

Scriniocassis priscus Scriniocassis weberi

\section{Figure 15: As Figure 5, but for the Family Scriniocassiaceae.}

Family Shublikodiniaceae (Fig. 16)

Range: Cysts from the Family Shublikodiniaceae occur in the late Triassic (FO of Rhaetogonyaulax wigginsii in the Carnian,

$360 \sim 230 \mathrm{Ma}$ ) to early Jurassic (LOs of Dapcodinium sacculus and Dapcodinium ovale in the mid-Pliensbachian, $187 \mathrm{Ma}$ ).

Quasi-synchronous events: LO of Rhaetogonyaulax rhaetica close to the Triassic-Jurassic Boundary, LO of Dapcodinium priscum. 


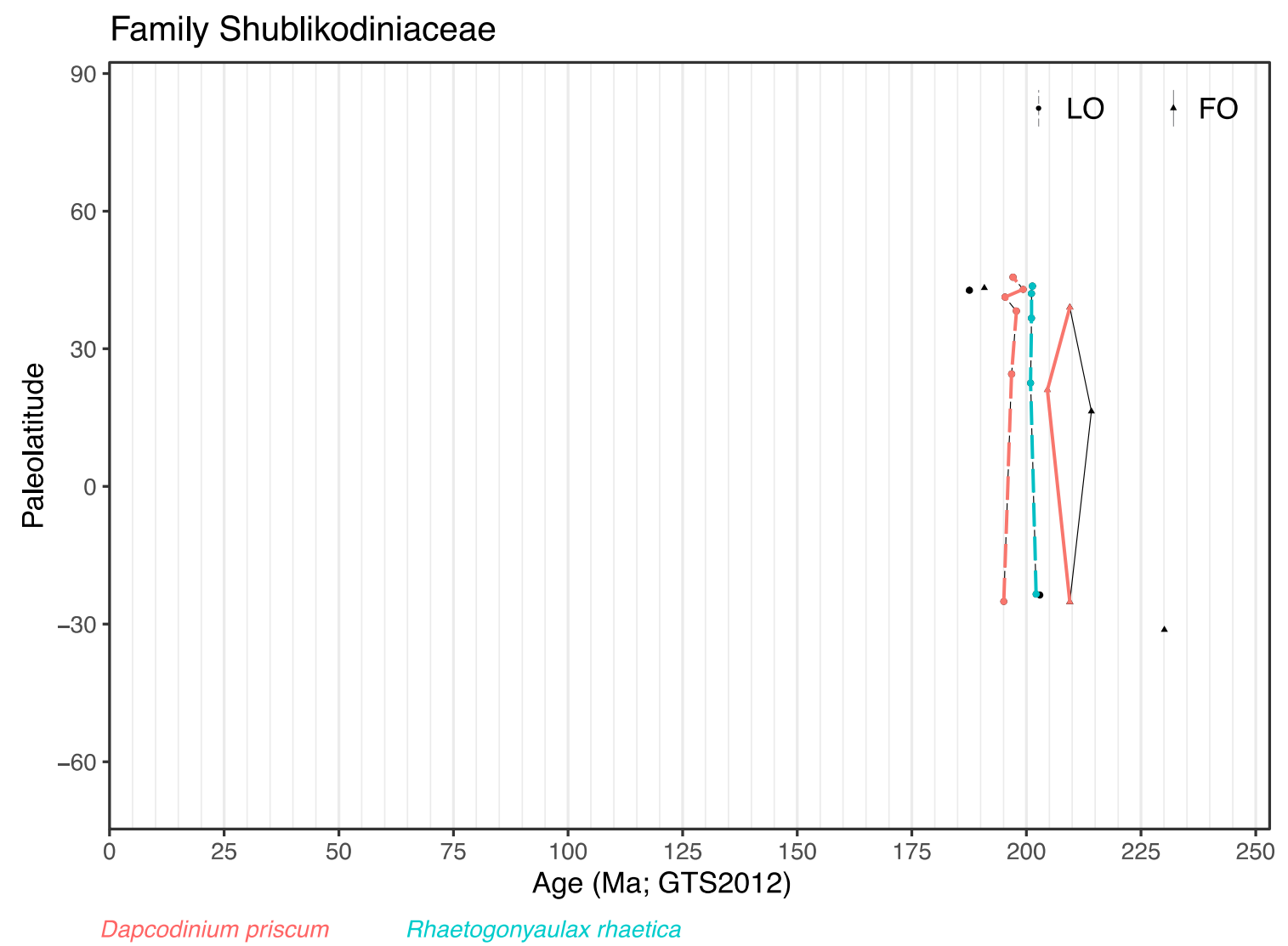

365 Figure 16: As Figure 5, but for the Family Shublikodiniaceae.

Family uncertain (Fig. 17)

Remarks: This group of which the family is uncertain does contain several stratigraphically synchronous species (Fig. 17). Ranges of species of Amiculosphaeridia, Atopodinium, Batiacasphaera, Cleistosphaeridium, Dingodinium, Distatodinium, Heslertonia, Labyrinthodinium, Membranilarnacia, Mendicodinium, Oligokolpoma and Valensiella are quasi-synchronous. 


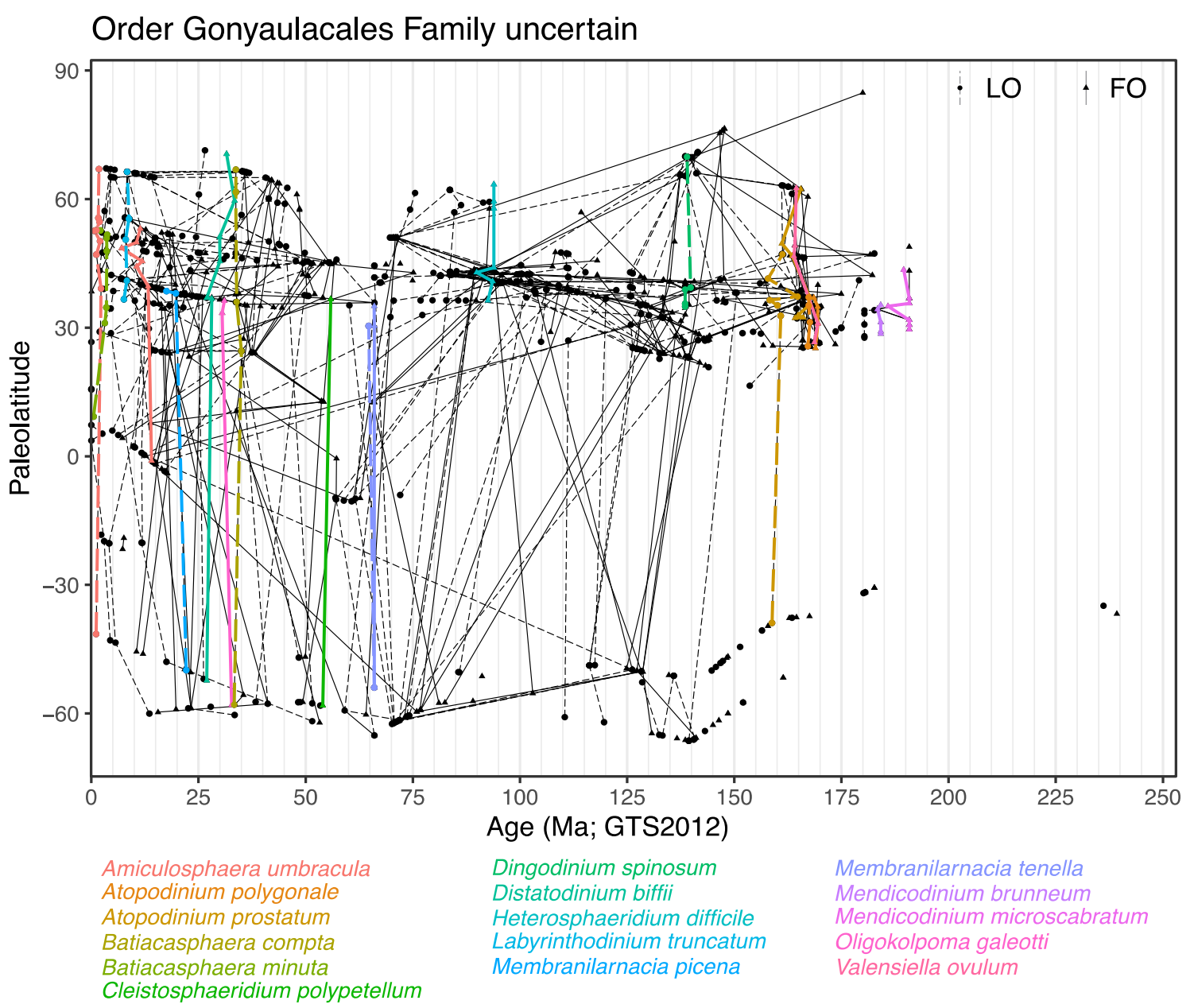

Figure 17: As Figure 5, but for the Order Gonyaulacales, Family uncertain.

Order uncertain

Family Comparodiniaceae (Fig. 18)

Range: Cysts from this Family range from the late Sinemurian (191 Ma, FO of Valvaeodinium spp.) to the mid-Valanginian (134 Ma, LO of Biorbifera johnwingii). All species except Valvaeodinium spinosum and Biorbia ferox have ranges restricted to the Northern Hemisphere.

Quasi-synchronous events: Range of Biorbifera johnwingii, FO of Valvaeodinium spinosum, LO of Valvaeodinium koessenium. 
https://doi.org/10.5194/essd-2021-158

Preprint. Discussion started: 8 July 2021

(c) Author(s) 2021. CC BY 4.0 License.

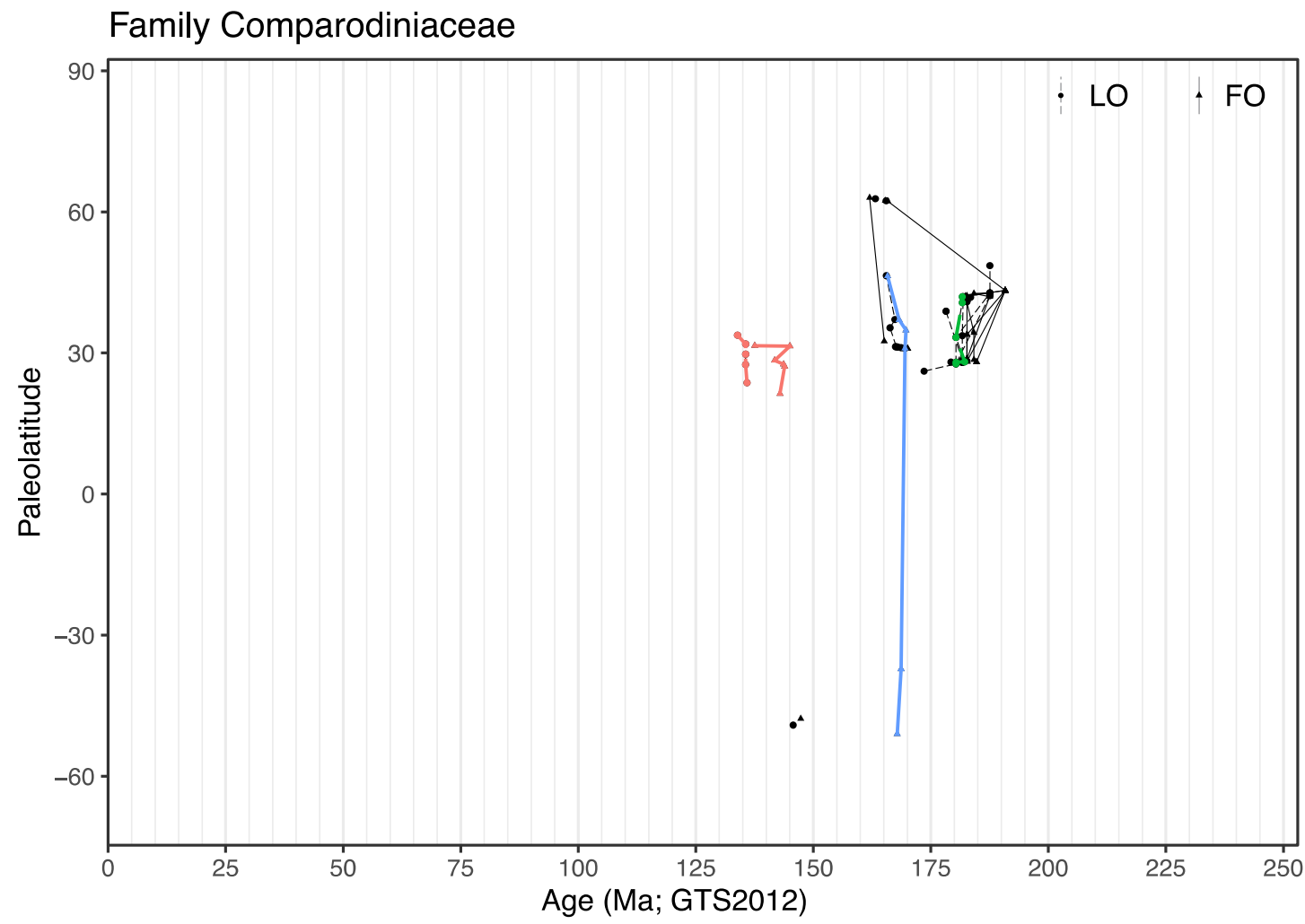

Biorbiferajohnwingii Valvaeodinium koessenium Valvaeodinium spinosum

Figure 18: As Figure 5, but for the Family Comparodiniaceae.

Family Stephanelytraceae (Fig. 19)

Range: Stephanelytraceae cysts comprine of one genus, which ranges from the Callovian ( 166 Ma) to the late Aptian ( 117 $\mathrm{Ma}$ ), and seems quasi-synchronous. 
https://doi.org/10.5194/essd-2021-158

Preprint. Discussion started: 8 July 2021

(c) Author(s) 2021. CC BY 4.0 License.

\section{Family Stephanelytraceae}

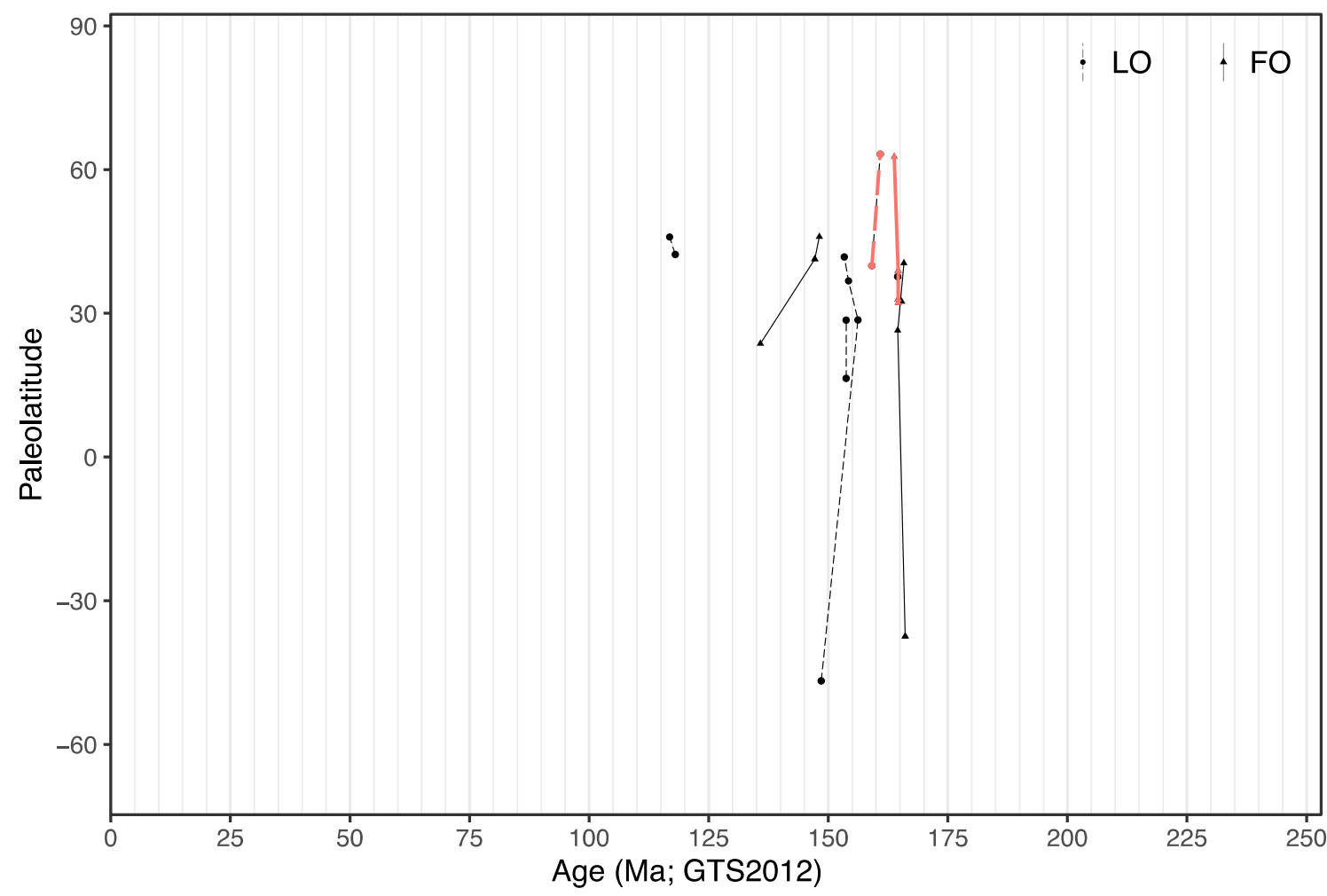

Stephanelytron redcliffense

390

Figure 19: As Figure 5, but for the Family Stephanelytraceae.

Order Peridiniales

Family Heterocapsaceae (Fig. 20)

395 Range: Heterocapsaceae range from the mid-Sinemurian (195 Ma, FO of Liasidium variabile) to the mid-Albian (105 Ma, LO of Angustidinium acribes).

Quasi-synchronous events: Range of Liasidium variabile and Parvocysta bullala, restricted to Northern Hemisphere midlatitudes. 


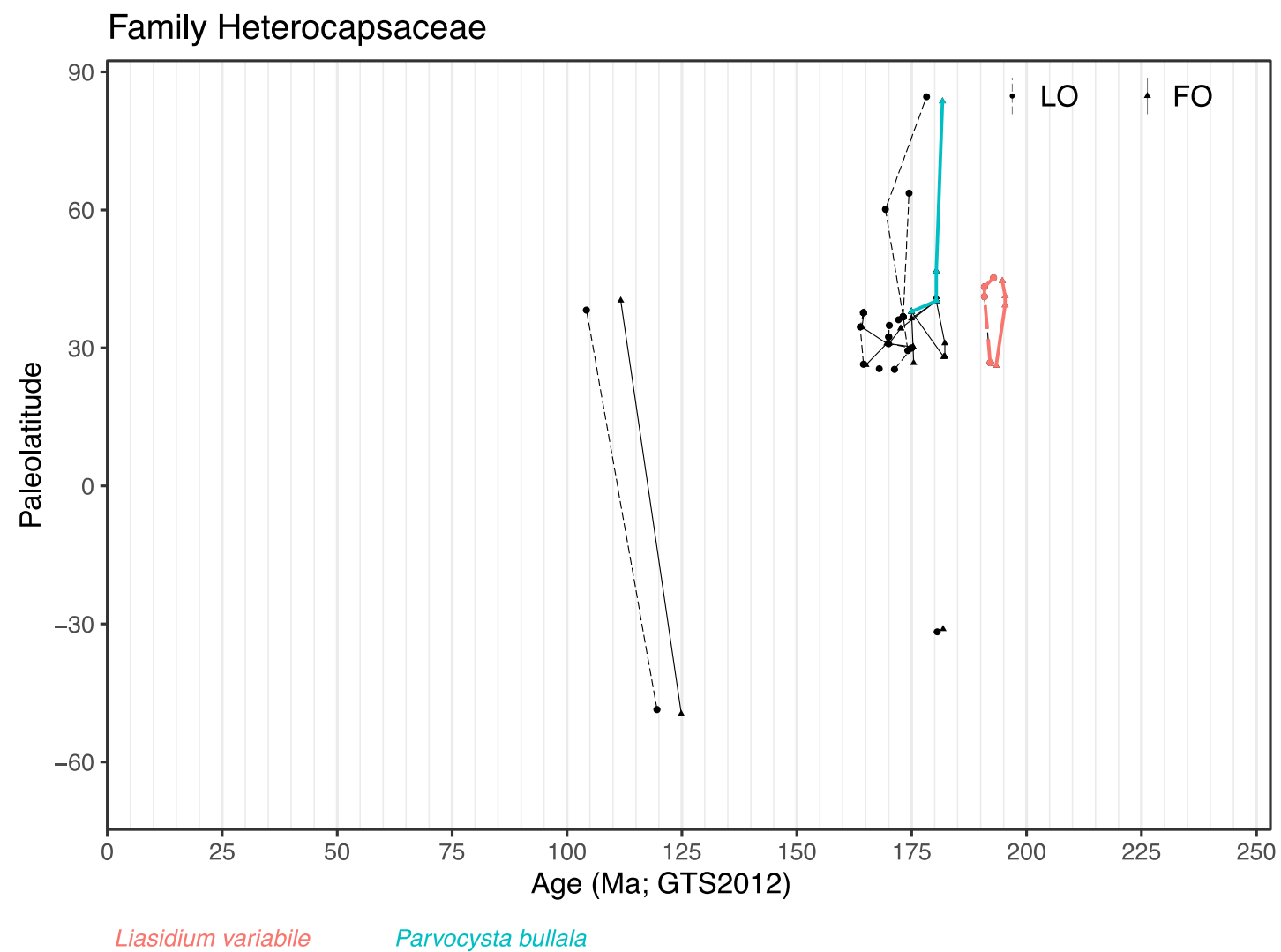

400

Figure 20: As Figure 5, but for the Family Heterocapsaceae.

Family Peridiniaceae

Subfamily Deflandreoideae (Fig. 21)

405 Range: Deflandroideae first occur on the Southern Hemisphere in the Oxfordian ( 161 Ma) with Pyxidiella spp. Isabelidinium and Eurydinium first appear in the Albian ( 109 Ma), and many species first appear in the late Cretaceous ( 95-66 Ma). The subfamily goes extinct with the LO of Sumatradinium spp. around $5 \mathrm{Ma}$ and appears to range longest in low and mid-latitudes. Deflandeoideae have many FO and LO entries on both hemispheres, particularly in the Late Cretaceous and early Paleogene. Quasi-synchronous events: Several species of Cerodinium, Manumiella, Trithyrodinium, and Isabelidinium have synchronous events in the Maastrichtian-Paleocene (70-60 Ma). 


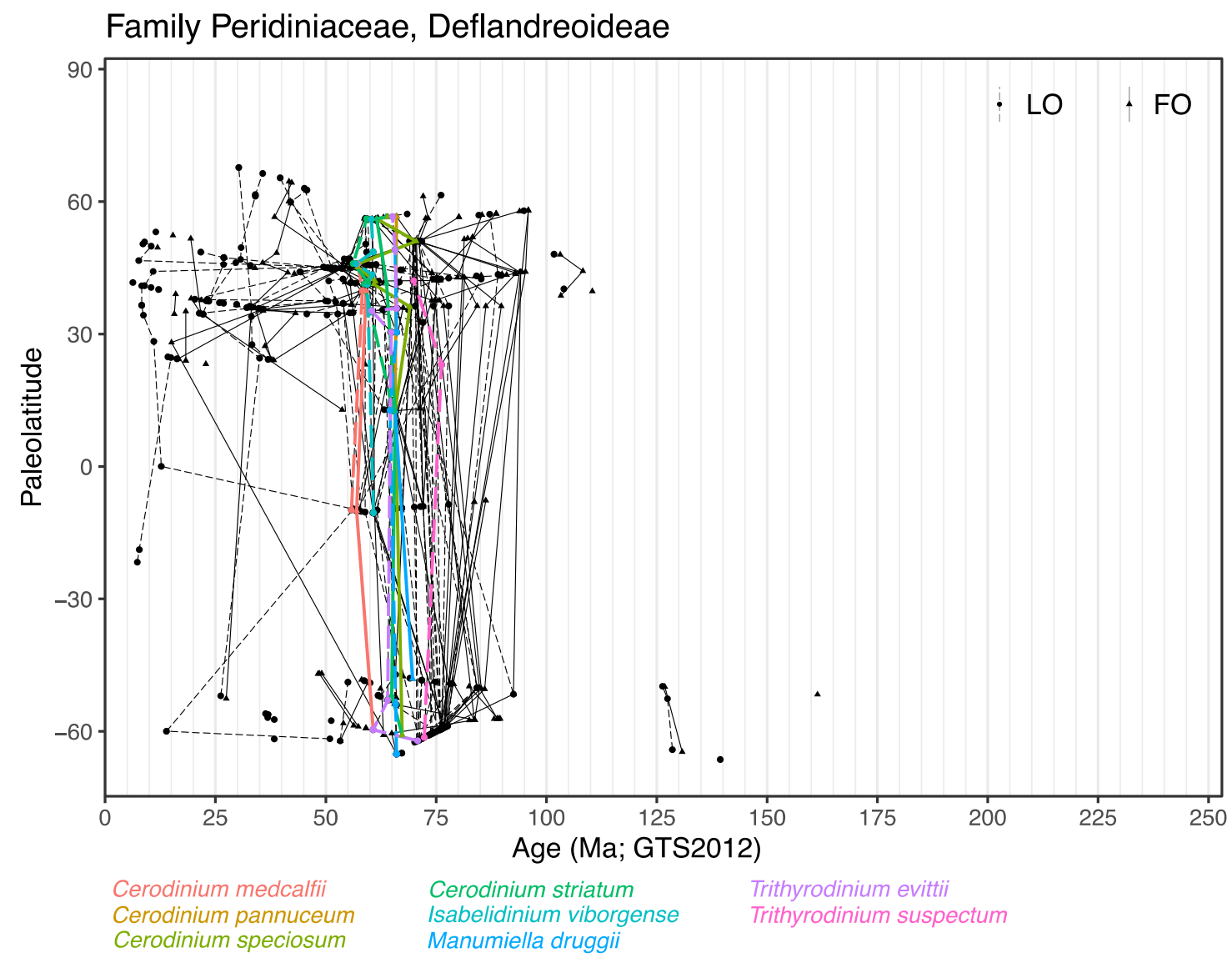

Figure 21: As Figure 5, but for the Family Peridiniaceae, subfamily Deflandreoideae.

415 Subfamily Palaeoperidinioideae (Fig. 22)

Range: The Palaeoperidinioideae range from the mid-Valanginian ( $135 \mathrm{Ma}$, FO of Subtilisphaera perlucida) to the late Oligocene ( $26 \mathrm{Ma}$, LO of Phthanoperidinium comatum).

Quasi-synchronous events: Range of Palaeoperidinium pyrophorum and the LO of Phthanoperidinium comatum. 


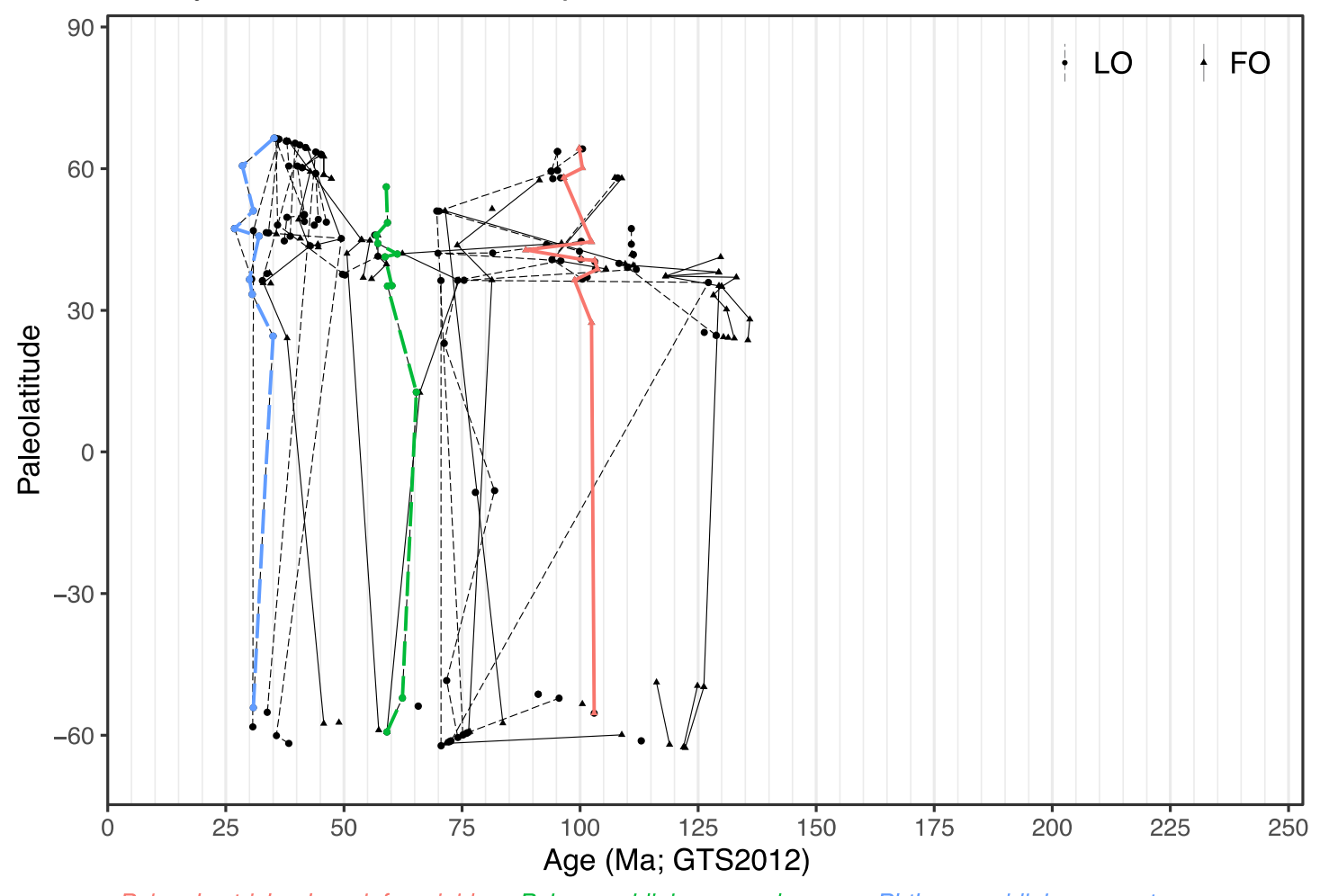

Palaeohystrichophora infusorioides Palaeoperidinium pyrophorum Phthanoperidinium comatum

Figure 22: As Figure 5, but for the Family Peridiniaceae, subfamily Palaeoperidinioideae.

Subfamily Wetzelielloideae (Fig. 23)

Range: Wetzelielloideae range from the mid-Paleocene ( 62 Ma, FO of Apectodinium homomorphum) to the late Oligocene ( $23 \mathrm{Ma}$, LO of Wetzeliella symmetrica). Diversification particularly in the Ypresian leads to many species with short 425 stratigraphic ranges, many of which are relatively synchronous latitudinally. Several species appear to range longer in the Northern Hemisphere than on equal paleolatitudes on the Southern Hemisphere. Many species lack chronostratigraphic tie in equatorial records. 


\section{Family Peridiniaceae, Wetzelielloideae}

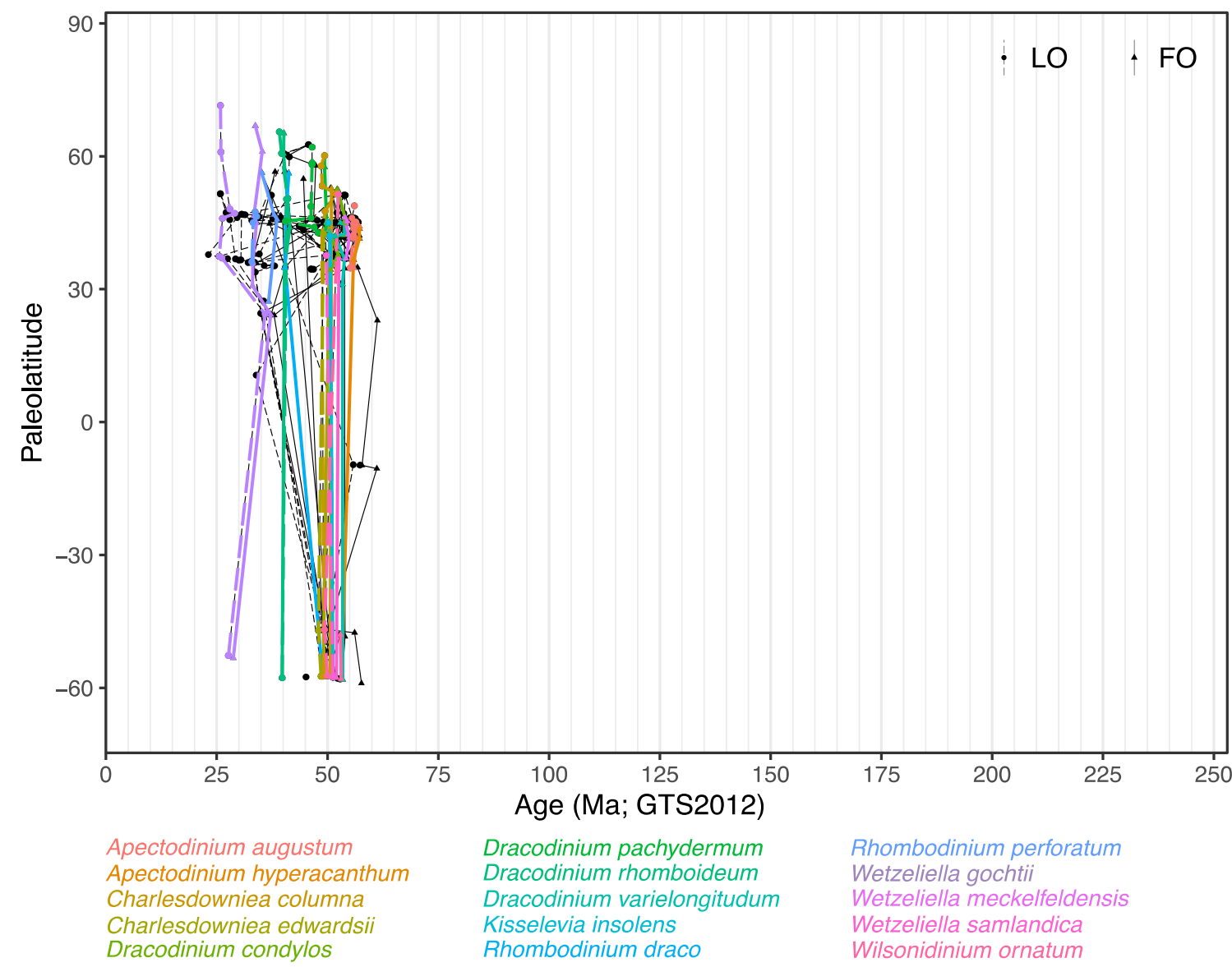

Figure 23. As Figure 5, but for the Family Peridiniaceae, subfamily Wetzelielloideae.

Other (Fig. 24)

Remarks: There is one quasi-synchronous event in this rest group: the FO of Ovoidinium cinctum around 129 Ma. 
Family Peridiniaceae, other

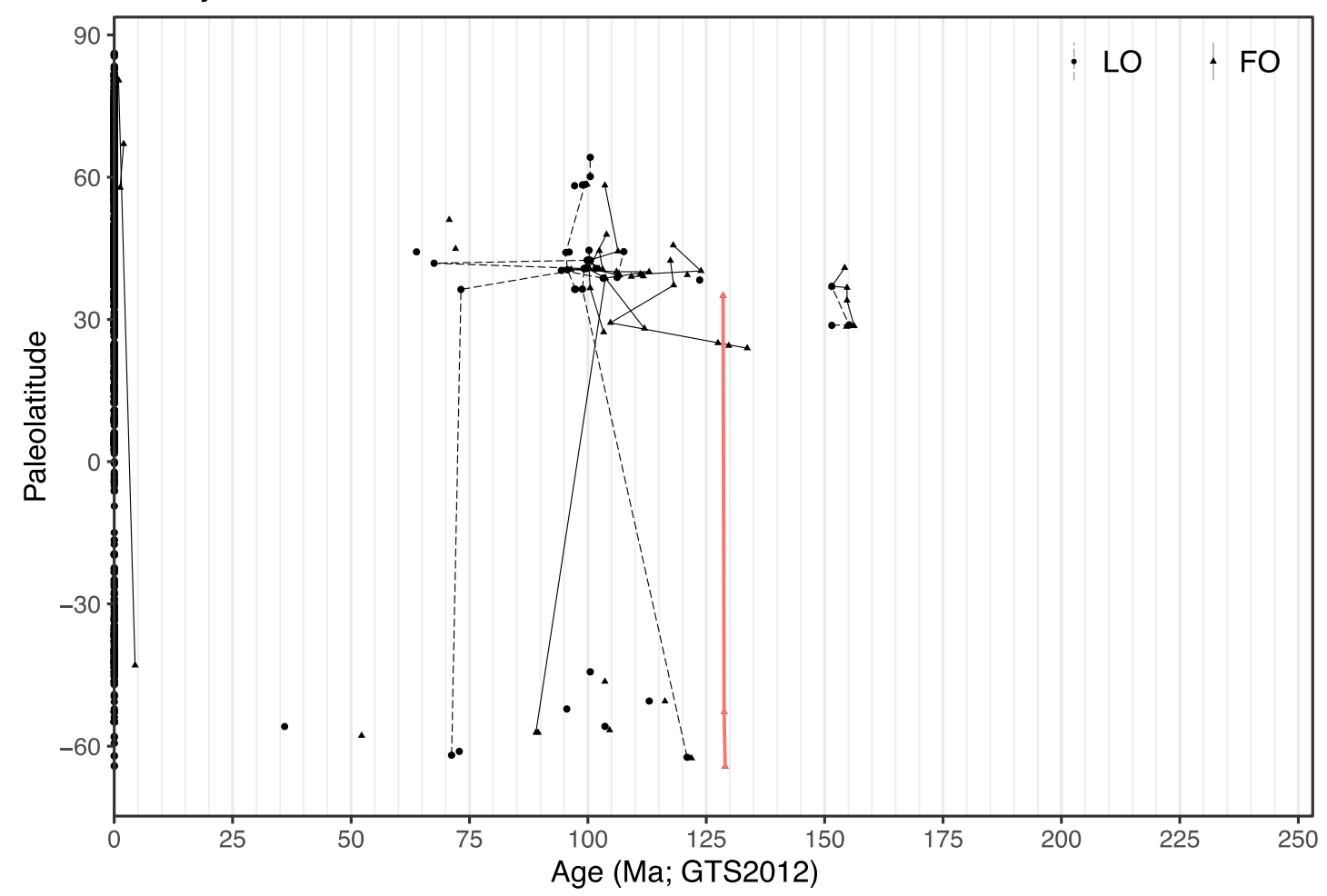

Figure 24: As Figure 5, but for other subfamilies in the Family Peridiniaceae.

Family Protoperidiniaceae (Fig. 25)

Range: Protoperidiniaceae first appear in the Santonian (FO of Phelodinium magnificum) and range into the modern with 30

440 species in 13 genera, which is exceptionally diverse for modern cyst families. Species have oldest first occurrences in low latitudes than in high latitudes. Events are extremely diachronous. 


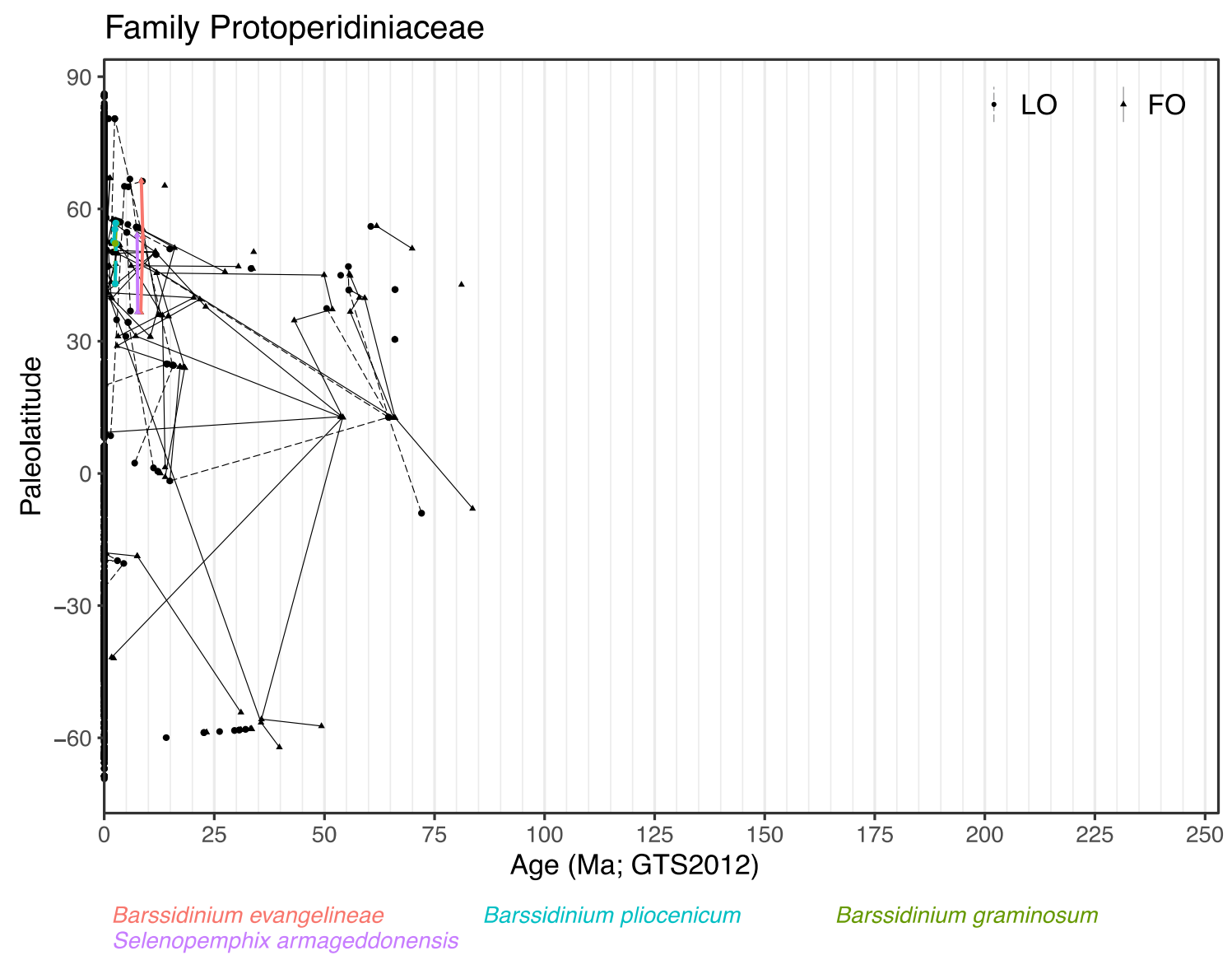

Figure 25: As Figure 5, but for the Family Protoperidiniaceae.

Order Nannoceratopsiales

Family Nannoceratopsiaceae (Fig. 26)

Range: Cysts from the Family Nannoceratopsiaceae occur from late Sinemurian (191 Ma, FO of Nannoceratopsis deflandrei senex) to the mid-Kimmeridgian ( 155 Ma, LO of Nannoceratopsis pellucida). 


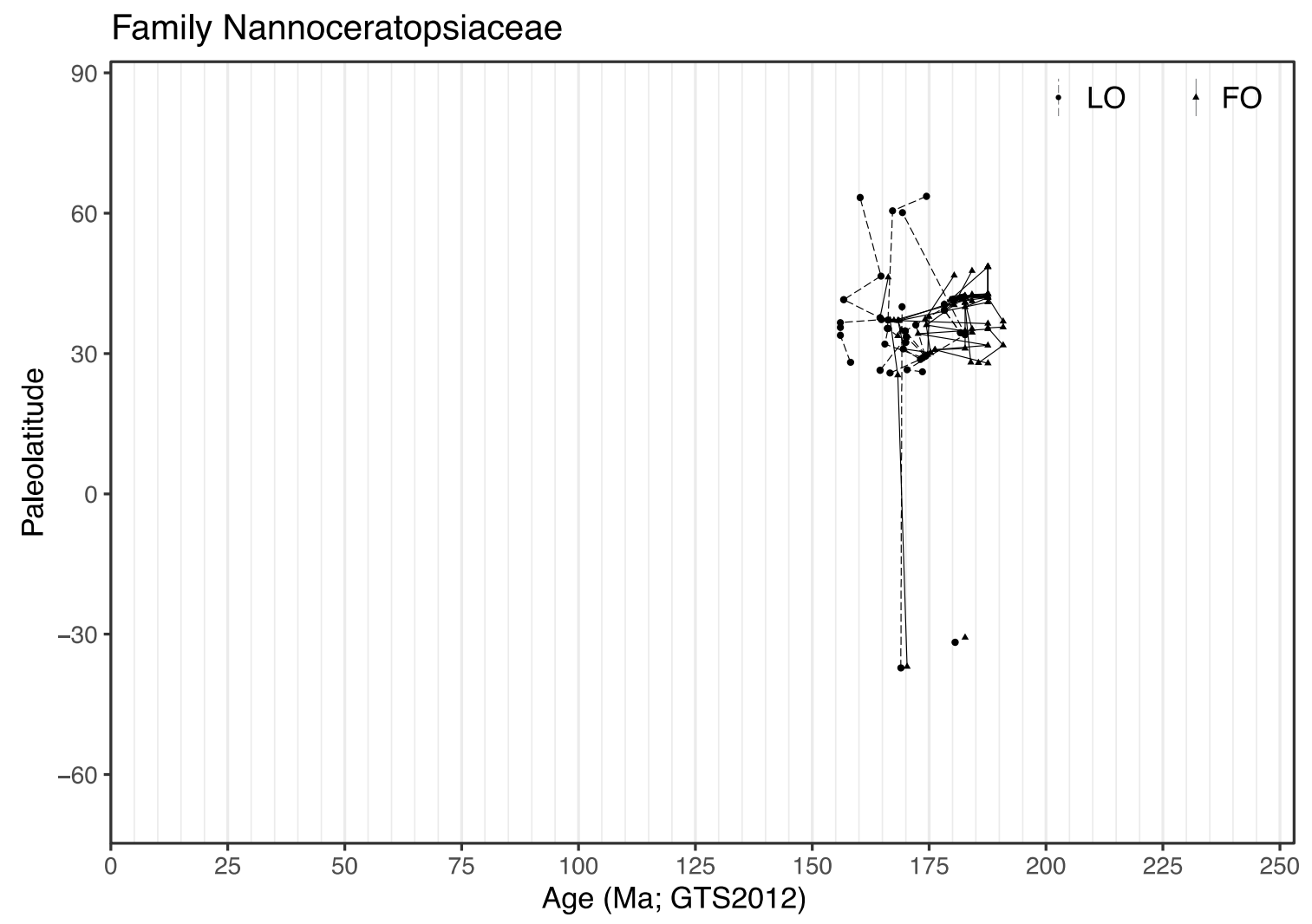

Figure 26: As Figure 5, but for the Family Nannoceratopsiaceae.

Order Ptychodiscales

Family Ptychodiscaceae (Fig. 27)

455 Range: This family only has entries in the late Cretaceous (91-66 Ma), where species represent fairly synchronous stratigraphic markers. Although cysts are only found in a relatively short geologic time interval, motile cells of Ptychodiscaceae are known from modern plankton. 


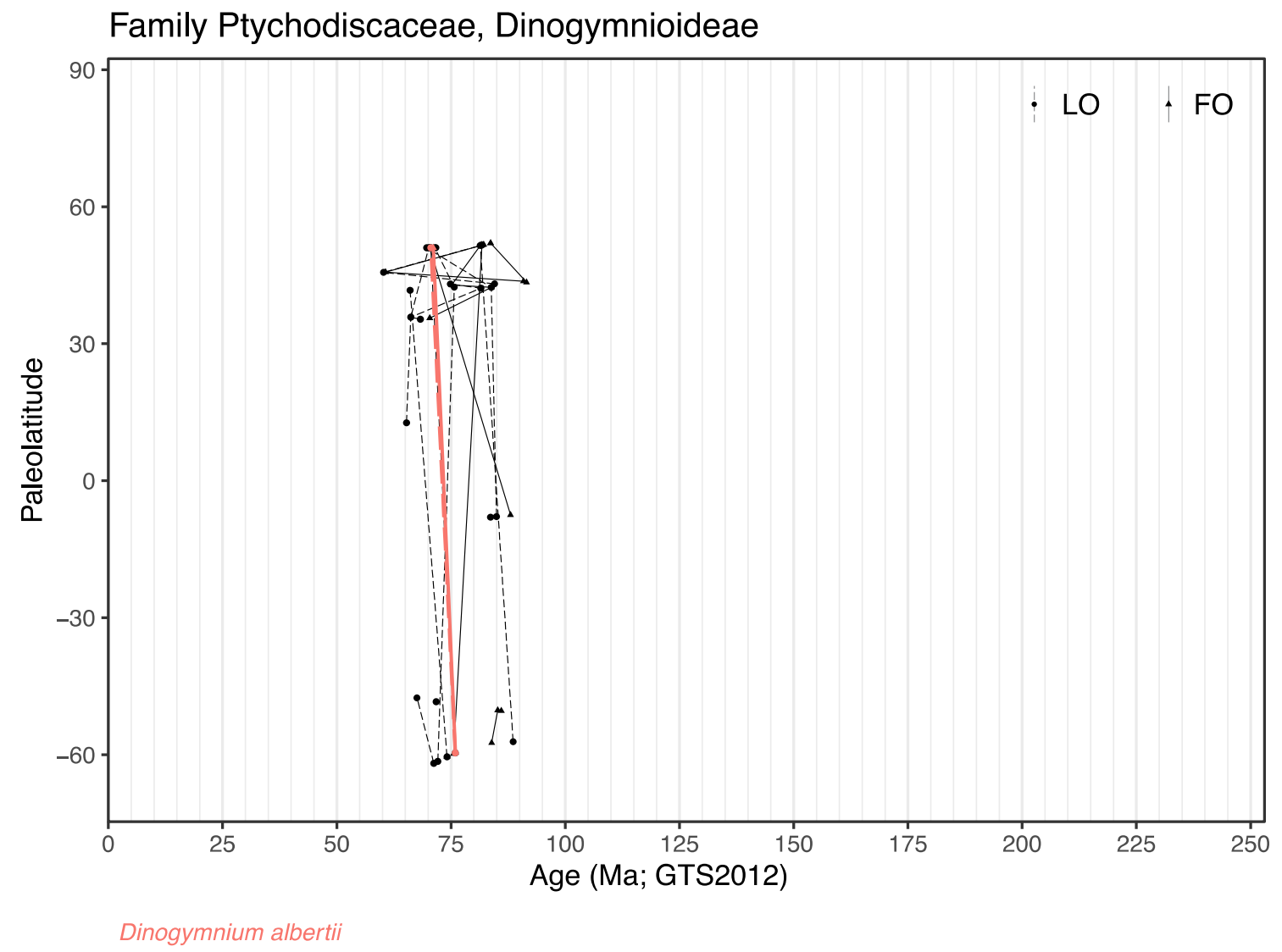

Figure 27: As Figure 5, but for the Family Ptychodiscaceae, subfamily Dinogymnioideae.

Order Suessiales

Family Suessiaceae (Fig. 28)

Range: Suessiaceae occur in the Triassic-early Jurassic (229-182 Ma).

Quasi-synchronous events: LO of Suessia swabiana. Other events are highly diachronous. 


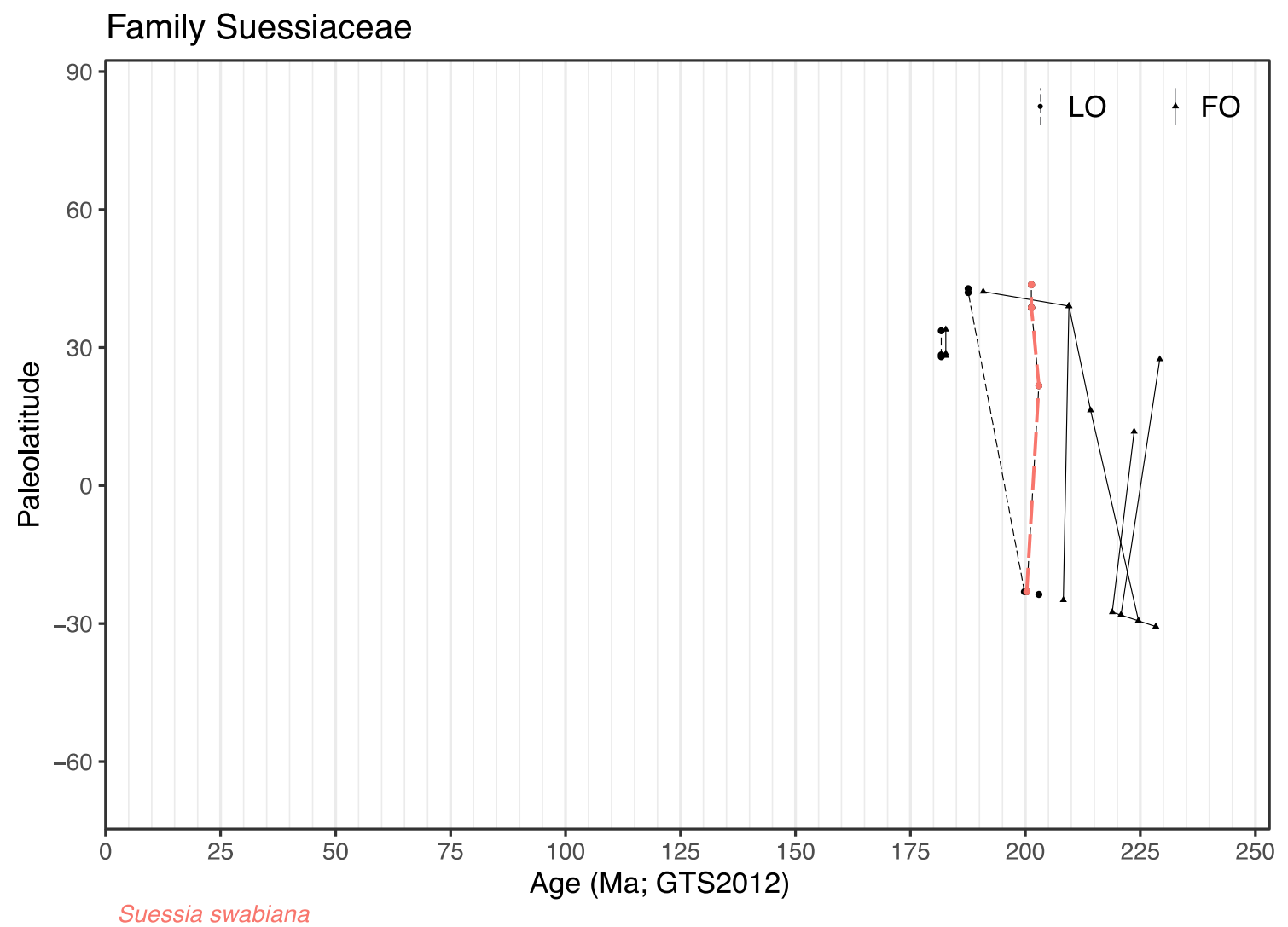

Figure 28: As Figure 5, but for the Family Suessiaceae.

\section{Discussion}

\subsection{Geographic extrapolation of dinocyst events}

A suite of dinocyst events throughout the entire stratigraphic record have quasi-synchronous ages across all latitudes (Fig. 528). Uneven geographic spread of data, with voids in the equatorial region and the Pacific Ocean, makes global synchroneity of these events highly uncertain. Still, the synchronous events confirm the potential and value of dinocyst biostratigraphy to date complex sedimentary systems. It also implies that ocean connectivity did allow dinocyst species to migrate globally, as far as their environmental tolerances permit.

Yet, the majority of dinocyst species have very diachronous ranges in DINOSTRAT, as well as latitudinally restricted

475 geographic spread, which confirms previous interpretations (Williams et al., 2004). With DINOSTRAT the underlying causes of this diachroniety can now be further explored. The shortness of some of the records used in this review may lead to 'false' events, i.e., those that represent re-appearance or temporal disappearance rather than 'true' first or last occurrences (FO and LO, respectively). The obvious false FOs and LOs have been removed from DINOSTRAT by omitting events that occur at the 
base or the top of the sections. Particularly rare species, or those occurring at the end of their preferred environmental niche, come and go in stratigraphic sections, and these lead to 'false' events in DINOSTRAT. Although such 'false' FOs and LOs may obscure a uniform age of events over latitudes, they may still have important regional stratigraphic significance, which is why their entries are retained in DINOSTRAT. As a result, age and region of the oldest FOs and youngest LOs have the most significance for reconstruction of evolutionary patterns. Although caving of material typically falsely increases the age of oldest FOs, this is unlikely a large influence on the entries in DINOSTRAT, as most studies come from core or outcrop material, and not from ditch cuttings, for which caving is much more likely. Reworking could falsely extend the age of youngest LOs of species. Although species that were reported as reworked in the papers have been omitted from DINOSTRAT, some reworked dinocysts could have been falsely identified as in situ in the original papers. It cannot be excluded that this causes some level of diachroniety in LOs, although this is unlikely a large factor.

The complexity of taxonomic concepts in some dinocyst genera (species definitions, or morphological continua) hinders proper evaluation of latitudinal synchroneity of events. The reviewed literature covers 50 years, during which taxonomic concepts of dinocysts species have iteratively evolved. The extensive synonymy database of Williams et al. (2017) does deliver crucial organization of the taxonomic framework. Still, some of the subtle morphological differences in species are limited to the expert eye of individual researchers, and these may not have been recognized by others (which occasionally led to the presentation of taxa on a genus level, instead of further specification to species level). Making the taxonomic framework consistent for all studies now included in DINOSTRAT would be a cardinal effort and will be part of the iterative setup of DINOSTRAT. For example, reviews of dinocyst taxonomic frameworks on a per-family basis, such as has been initiated for the Spiniferites complex (e.g., Mertens and Carbonell-Moore, 2018) could help adjusting inconsistencies in species concepts, and their stratigraphic occurrence. In any case, it must be stressed that the quality of any biostratigraphic marker is defined not only by the accuracy of the tie to the chronostratigraphic time scale, or global consistency of the age of FO or LOs, but also by their morphological distinctiveness.

Events may also appear diachronous in DINOSTRAT because of inadequate or inaccurate tie to the chronostratigraphic time scale. In such cases, small diachroniety $\left(\sim 10^{4-5} \mathrm{yr}\right)$ may be related to the inherent assumption of linear sedimentation rates between age tie points. Larger diachroniety $\left(\sim 10^{5-6} \mathrm{yr}\right)$ may be because the zonation through which dinocyst events were calibrated to the chronostratigraphic time scale is diachronous. For calibrations against magnetostratigraphy (Tier 1,2$)$ this is unlikely, and could occur only when magnetochrons were wrongly interpreted in the sites used. For events calibrated against Cenozoic nannoplankton and foraminifer zonations (in Tier 3,4) this is also unlikely, as these events are relatively robustly calibrated to chronostratigraphy (Watkins and Raffi, 2020; Petrizzo et al., 2020). Less robust are the Mesozoic ammonite zonation schemes, which have shown to be quite diachronous themselves latitudinally (e.g., Ogg and Hinnov, 2012a, b and references therein). The geographic variability in ages of zone boundaries, but also numerous adjustments of zone definitions 510 throughout the past 50 years, further complicates accurate tie of dinocyst events with ammonite data to the GTS2012. So far, the majority of Mesozoic dinocyst events were calibrated against these ammonite zonations, which makes their absolute tie to 
the chronostratigraphic time scale most uncertain. A major challenge for future versions of DINOSTRAT is to improve the independent age control of Mesozoic calibrated dinocyst events.

Also, ecological reasons could cause geographically diachronous events. When local environmental or depositional conditions change, assemblages adjust, which leads to local and temporal (dis)appearances of species that may be falsely interpreted as extinction or origination events. If so, dinocyst taxa associated to the most dynamic environmental niches on the continental shelf are expected to have the most diachronous events. Indeed, there are particularly diachronous events in Goniodomaceae and Protoperidinioideae - both Families are associated to near-shore depositional settings (Zonneveld et al., 2013; Sluijs et al., 2005; Frieling and Sluijs, 2018), that are most environmentally dynamic. Settings in which these species occur offshore, such as upwelling regions (Sangiorgi et al., 2018), or hyperstratified waters (Reichart et al., 2004; Cramwinckel et al., 2019), are environmentally equally dynamic. In contrast, families typically associated to offshore conditions, such as the Wetzeliellioideae (Frieling and Sluijs, 2018) reveal much more synchronous events. For regional stratigraphy, the diachroniety is of less concern because these events can still be used for regional stratigraphic correlation (e.g., as in Vieira and Jolley, 2020). It does mean that for such species, dinocyst biostratigraphy applies regionally, and caution should be taken to extrapolate event ages far outside of these regions. There are also species that clearly show regional inconsistency of origination or extinction ages as a result of climate change - e.g., Melitasphaeridium choanophorum had a much wider geographic distribution during warmer past climates and a progressively younger LO in lower latitudes as climate cooled (Fig. 4).

Diachroniety is usually larger between latitudinal bands than within latitudinal bands. The sparsity of records from the Southern high latitudes complicates robust assessment of interhemispheric differences in dinocyst event ages. In the Mesozoic, the diachroneity is likely related to the inadequate tie of events to the international time scale. DINOSTRAT is short of Mesozoic records that are tied to other stratigraphic tools than ammonites. For the Cenozoic, the diachroneity between hemispheres cannot be explained by inadequate calibration, since many events are calibrated against magnetostratigraphy. For those, environmental reasons must be at play. While in the early Paleogene many dinocyst events are quasi-synchronous (events within the Wetzeliellioideae, of Cerodinium and Palaeoperidinium), in the late Paleogene and Neogene diachroneity seems to become stronger. This may be in part because of stronger latitudinal temperature gradients as global average climate cools (Cramwinckel et al., 2018; Westerhold et al., 2020), which creates more diverse ecological niches and complicates latitudinal migration.

Many dinoflagellate cyst species and higher generic ranks have their oldest first occurrence and youngest last occurrence in Northern Hemisphere mid-latitudes (see, e.g., Areoligeraceae, Cladopyxiaceae, Comparodiniaceae, Goniodomaceae, 540 Nannoceratopsiaceae, Palaeoperidinioideae, Wetzeliellioideae; Figs. 5, 7, 18, 8, 26, 22, 23). This may be because of a much higher density of records at those latitudes. However, the vast continental shelf area in Europe throughout the Mesozoic and much of the Cenozoic did likely serve as the perfect habitat for taxa to find a new niche and to linger on. A higher record density in Southern Hemisphere and equatorial regions should shed light on this idea. 


\subsection{Evolutionary patterns in dinocyst (sub-) families}

DINOSTRAT presents for the first time a quantitative overview of stratigraphic and paleolatitudinal distribution of fossil and modern dinoflagellate cyst taxa. Through that, it refines with coherent, independent, open-access data the evolutionary patterns presented previously (e.g., Fensome et al., 1993; McRae et al., 1996), and adds their latitudinal distribution through time. Following up on 60 million years of experimentation in cyst-formation among a wide group of dinoflagellates (Figs. 13, 15, 16, 18-20, 26, 28), Gonyaulacoid dinocysts developed their most fundamental taxonomic features in a rapid diversity phase in the Bajocian ( 169 Ma) likely on vast continental shelf areas on the European continent (Figs. 5, 9-12, 17). The extremely high diversity in Gonyaulacoid dinocysts in the late Jurassic and Cretaceous is reflected in the density of the events in DINOSTRAT. Peridinioid dinocyst taxa strongly diversify in the late Cretaceous and Paleogene (Figs. 21-25). The decline in dinocyst diversity in the Neogene is visible in the scarcity of FOs from 25 Myrs onwards (except in Protoperidinioideae). DINOSTRAT allows to further explore spatial patterns in dinoflagellate cyst evolution in the future.

\subsection{Functionality of DINOSTRAT}

Once downloaded, DINOSTRAT can be filtered by location, allowing users to compare newly generated dinocyst chronologies to nearby calibrated regional dinocyst events. DINOSTRAT can also be filtered by species, genus or higher taxonomic rank, for further evaluation of the latitudinal spread of any species of interest. The data in DINOSTRAT is readily visualized in Supplement 2, and these plots can be adjusted and reproduced using the R markdown file "plot creator" in Bijl, 2021. The community is invited to contact the first author either via email or through GitHub, with suggestions, error reports, and/or additional papers or data to be entered, so that the data content of DINOSTRAT is iteratively improved.

\subsection{Future directions}

DINOSTRAT will be regularly updated. Annual minor updates include addition of sites, adjustments in the current entries (e.g., through the feedback process), or minor revisions in taxonomy/stratigraphy. Major updates will occur in a 3-year cycle

565 and are the result of new Geologic Time Scales, or profound revisions in dinocyst taxonomic concepts. Major updates will be accompanied by a short communication in this journal, minor updates will be communicated through the GitHub repository. Updates of the Geologic Time Scale (e.g., to GTS2020 (Gradstein et al., 2020)) will be implemented once the metadata of that Geologic Time scale have become available. All versions of DINOSTRAT will remain archived on GitHub.

\section{Data availability}

570 The database is available under a CC-BY 4.0 license on GitHub (Bijl, 2021; https://github.com/bijlpeter83/DINOSTRAT.git; DOI:10.5281/zenodo.4471204). The database consists of $4 \mathrm{csv}$ files: (1) "Paleolatitude.csv"; paleolatitude and present-day position of sites in DINOSTRAT, (2) “modernsp.csv"; the site locations of core top sediments, (3) "modernsp.csv"; a modified 
modern dinocyst dataset, and (4) "Dinoevents_Jan2021.csv"; the calibrated dinocyst events. "Plot creator.Rmd" is an R markdown file to reproduce the figures presented in this paper.

\section{Conclusions}

This paper presents the database DINOSTRAT version 1.0 (Bijl, 2021), a database containing $>8500$ entries of regional dinoflagellate cyst first and last occurrences (events) from 1914 species, in 189 sites. Geographic distribution of sites used in DINOSTRAT is strongly concentrated in the northern hemisphere mid-latitude, notably in Europe and the North Atlantic, and few sites are in the Pacific or Southern Hemisphere. Ages of events were calibrated using their tie to the Geologic Time Scale.

The paper presents the location and age of origin of modern dinoflagellate cyst species, reviews the age range and geographic spread modern and extinct dinoflagellate cyst taxa and highlights the most latitudinally synchronous dinoflagellate cyst events. Many dinocyst taxa show quasi-synchronous events latitudinally, which can be widely used to stratigraphically date complex sedimentary sequences. Latitudinal diachroneity in events can be the result of either inadequate tie to the chronostratigraphic time scale, false interpretations of 'true' events, complicated species concepts or paleoceanographic reasons. In any case, it dictates caution to extrapolate ages of dinocyst events to far distances, and demonstrates the need for regionally calibrated dinocyst zonations, which DINOSTRAT here provides. It further provides solid foundation to review spatio-temporal patterns in dinoflagellate cyst evolution, dispersal, and extinction. DINOSTRAT is freely available under CC-BY 4.0 license. It allows the user to filter by region, or by species, genus, or higher taxonomic rank.

\section{Supplements}

- Supplement 1: Table of conversions of published zones to those in GTS2012

- Supplement 2: Zip file containing ages and latitudes of events in individual dinoflagellate cyst species (1914 plots), grouped per genus (460 plots), per Family (28 plots), of modern cyst species (92 plots), and the range charts for all Sites (189 plots).

\section{Competing interests}

Author declares no conflict of interests

\section{Acknowledgements}

The LPP Foundation has financially supported the development of DINOSTRAT. I thank Henk Brinkhuis, Bas vd Schootbrugge and Appy Sluijs for useful discussions. The 'Advanced course in organic-walled dinoflagellate cyst taxonomy, stratigraphy and paleoecology' has been a great 'playground' to discuss progress in the field, and for that I have Martin Head, 
https://doi.org/10.5194/essd-2021-158

Preprint. Discussion started: 8 July 2021

(c) Author(s) 2021. CC BY 4.0 License.

(c) (i)

600 Martin Pearce, Jörg Pross, Jim Riding, Francesca Sangiorgi and Poul Schiøler to thank. I acknowledge the then research assistants who helped building predecessors of DINOSTRAT: Tjerk Veenstra, Keechy Akkerman and Caroline van der Weijst. Thanks to Martin Schobben for help with the data analysis and visualization in R, and Douwe van Hinsbergen for help reconstructing the paleolatitudes of the sites. 
https://doi.org/10.5194/essd-2021-158

Preprint. Discussion started: 8 July 2021

(c) Author(s) 2021. CC BY 4.0 License.

\section{References}

Açıkalın, S., Vellekoop, J., Ocakoğlu, F., Yılmaz, İ. Ö., Smit, J., Altıner, S. Ö., Goderis, S., Vonhof, H., Speijer, R. P., Woelders, L., Fornaciari, E. and Brinkhuis, H.: Geochemical and palaeontological characterization of a new K-Pg Boundary locality from the Northern branch of the Neo-Tethys: Mudurnu - Göynük Basin, NW Turkey, Cretaceous Research, 52, 251-

$610 \quad 267,2015$.

Århus, N., Birkelund, T. and Smelror, M.: Biostratigraphy of some Callovian and Oxfordian cores off Vega, Helgeland, Norsk Geologisk Tidsskrift, 69, 39-56, 1989.

Aubry, A. M. R., De Schepper, S. and de Vernal, A.: Dinocyst and acritarch biostratigraphy of the Late Pliocene to Early Pleistocene at Integrated Ocean Drilling Program Site U1307 in the Labrador Sea, Journal of Micropaleontology, 39(1), 41-

615 60, doi:10.5194/jm-39-41-2020, 2020.

Awad, W. K. and Oboh-Ikuenobe, F. E.: Early Paleogene dinoflagellate cysts from ODP Hole 959D, Côte d'Ivoire-Ghana Transform Margin, West Africa: New species, biostratigraphy and paleoenvironmental implications, Journal of African Earth Science, 123, 123-144, doi:10.1016/j.jafrearsci.2016.07.014, 2016.

Awad, W. K. and Oboh-Ikuenobe, F. E.: Paleogene-early Neogene paleoenvironmental reconstruction based on palynological analysis of ODP Hole 959A, West Africa, Marine Micropaleontology, 148, 29-45, 2019.

Bailey, D. A., Milner, P. and Varney, T.: Some dinoflagellate cysts from the Kimmeridge Clay Formation in North Yorkshire and Dorset, U.K., Proceedings of the Yorkshire Geological Society, 51, 235-243, 1997.

Baruffini, L., Lottaroli, F. and Torricelli, S.: Integrated high-resolution stratigraphy of the lower oligocene tusa tuffite formation in the Calabro-Lucano area and sicily (southern Italy), Rivista Italiana di Paleontologia e Stratigrafia, 108(3), 457$625478,2002$.

Besems, R.: Dinoflagellate cyst biostratigraphy of Tertiary and Quaternary deposits of offshore NW Borneo, Geological Society of Malaysia, bulletin, 33, 65-93, 1993.

Biffi, U. and Manum, S. B.: Late Eocene-Early Miocene dinoflagellate cyst stratigraphy from the Marche region (Central Italy), Bulletino della Società Paleontologica Italiana, 27(2), 163, 1988.

Bijl, P. K. and Brinkhuis, H.: A new genus and two new species of dinoflagellate cysts from lower Eocene marine sediments of the Wilkes Land Margin, Antarctica, Review of Palaeobotany and Palynology, 220, 88-97, doi:10.1016/j.revpalbo.2015.05.004, 2015.

Bijl, P. K., Sluijs, A. and Brinkhuis, H.: A magneto- chemo- stratigraphically calibrated dinoflagellate cyst zonation of the early Paleogene South Pacific Ocean, Earth-Science reviews, 124, 1-31, 2013a.

635 Bijl, P. K., Bendle, A. P. J., Bohaty, S. M., Pross, J., Schouten, S., Tauxe, L., Stickley, C. E., McKay, R. M., Roehl, U., Olney, M., Sluijs, A., Escutia, C., Brinkhuis, H. and scientists, E. 318: Eocene cooling linked to early flow across the Tasmanian Gateway , PNAS, 110(24), 9645-9650, doi:https://doi.org/10.1073/pnas.1220872110, 2013b. 
https://doi.org/10.5194/essd-2021-158

Preprint. Discussion started: 8 July 2021

(c) Author(s) 2021. CC BY 4.0 License.

Bijl, P. K., Sluijs, A. and Brinkhuis, H.: Erratum to "A magneto- and chemostratigraphically calibrated dinoflagellate cyst zonation of the early Paleogene South Pacific Ocean" [Earth Sci. Rev. 124 (2013) 1-31], Earth-Science reviews, 134, 160-

163, doi:10.1016/j.earscirev.2014.03.010, 2014.

Bijl, P. K., Brinkhuis, H., Egger, L. M., Eldrett, J. S., Frieling, J., Grothe, A., Houben, A. J. P., Pross, J., Sliwinska, K. K. and Sluijs, A.: Comment on 'Wetzeliella and its allies - the "hole" story: a taxonomic revision of the Paleogene dinoflagellate subfamily Wetzelielloideae’ by Williams et al. (2015), Palynology, 1-7, doi:10.1080/01916122.2016.1235056, 2016.

Bijl, P. K., Houben, A. J. P., Bruls, A., Pross, J. and Sangiorgi, F.: Stratigraphic calibration of Oligocene-Miocene organicwalled dinoflagellate cysts from offshore Wilkes Land, East Antarctica, and a zonation proposal, Journal of Micropalaeontology, 37(1), 105-138, doi:10.5194/jm-37-105-2018, 2018.

Bowman, V. C., Francis, J. E., Riding, J. B., Hunter, S. J. and Haywood, A. M.: A latest Cretaceous to earliest Paleogene dinoflagellate cyst zonation from Antarctica, and implications for phytoprovincialism in the high southern latitudes, Review of Palaeobotany and Palynology, 171, 40-56, doi:10.1016/j.revpalbo.2011.11.004, 2012.

Bijl, P.K.: DINOSTRAT V1.0, available at https://github.com/bijlpeter83/DINOSTRAT.git;_DOI:10.5281/zenodo.4471204, 2021.

Bowman, V., Ineson, J., Riding, J., Crame, J., Francis, J., Condon, D., Whittle, R. and Ferraccioli, F.: The Paleocene of Antarctica: Dinoflagellate cyst biostratigraphy, chronostratigraphy and implications for the palaeo-Pacific margin of Gondwana, Gondwana Research, 38, 132-148, doi:10.1016/j.gr.2015.10.018, 2016.

655 Bravo I, Figueroa RI.: Towards an Ecological Understanding of Dinoflagellate Cyst Functions, Microorganisms 2(1), 11-32, doi:10.3390/microorganisms2010011, 2014.

Brinkhuis, H.: Late Eocene to Early Oligocene dinoflagellate cysts from the Priabonian type-area (northeast Italy); biostratigraphy and palaeoenvironmental interpretation, Palaeogeography, Palaeoclimatology, Palaeoecology, 107, 121-163, 1994.

660 Brinkhuis, H. and Biffi, U.: Dinoflagellate cyst stratigraphy of the Eocene / Oligocene transition in Central Italy, Marine Micropaleontology, 22, 131-183, 1993.

Brinkhuis, H., Powell, A. J. and Zevenboom, D.: High-resolution dinoflagellate cyst stratigraphy of the Oligocene / Miocene transition interval in northwest and central Italy, in: Neogene and Quaternary Dinoflagellate Cysts and Acritarchs, edited by M. J. Head and J. H. Wrenn, American Association of Stratigraphic Palynologists Foundation, Dallas., 1992.

Brinkhuis, H., Bujak, J. P., Smit, J., Versteegh, G. J. M. and Visscher, H.: Dinoflagellate-based sea surface temperature reconstructions across the Cretaceous-Tertiary boundary, Palaeogeography, Palaeoclimatology, Palaeoecology, 141(1-2), 6783, 1998.

Brinkhuis, H., Munsterman, D. M., Sengers, S., Sluijs, A., Warnaar, J. and Williams, G. L.: Late Eocene to Quaternary dinoflagellate cysts from ODP Site 1168, off western Tasmania, edited by N. Exon and J. P. Kennett, Proceedings of the ODP, Scientific results, Leg 189, U.S. Government Printing Office, College Station, Texas., 2003a. 
https://doi.org/10.5194/essd-2021-158

Preprint. Discussion started: 8 July 2021

(c) Author(s) 2021. CC BY 4.0 License.

(c) (i)

Brinkhuis, H., Sengers, S., Sluijs, A., Warnaar, J. and Williams, G. L.: Latest Cretaceous to earliest Oligocene, and Quaternary dinoflagellates from ODP Site 1172, East Tasman Plateau, edited by N. Exon and J. P. Kennett, Proceedings of the ODP, Scientific results, Leg 189, U.S. Government Printing Office, College Station, Texas., 2003b.

Brown, S. and Downie, C.: Dinoflagellate cyst biostratigraphy of late Paleocene and early Eocene sediments from Holes 552,

675 553A, and 555, Leg 81, Deep Sea Drilling Project ( Rockall Plateau), Proceedings of the deep sea drilling project, Initial reports, vol. 81, Washington, U.S.A., 565-579, 1984.

Brown, S. and Downie, C.: Dinoflagellate cyst stratigraphy of Paleocene to Miocene sediments from the Goban Spur (Sites 548-550, Leg 80)., Proceedings of the Deep Sea Drilling Project, Initial reports, vol. 80, Washington, U.S.A., 643-651, 1985. Bucefalo Palliani, R. and Riding, J. B.: Lower Toarcian palynostratigraphy of Pozzale, central Italy, Palynology, 21, 91-103, 680 1997a.

Bucefalo Palliani, R. and Riding, J. B.: The influence of palaeoenvironmental change on dinoflagellate cyst distribution. An example from the Lower and Middle Jurassic of Quercy, southwest France, Bulletin du Centre de recherches Elf exploration production, 21(1), 107-123, 1997b.

Bucefalo Palliani, R. and Riding, J. B.: A palynological investigation of the Lower and lowermost Middle Jurassic strata 685 (Sinemurian to Aalenian) from North Yorkshire, UK, Proceedings of the Yorkshire Geological Society, 53, 1-16, 2000.

Bucefalo Palliani, R. and Riding, J. B.: Biostratigraphy, Provincialism and evolution of European Early Jurassic (Pliensbachian to early Toarcian) dinoflagellate cysts, Palynology, 27, 179-214, 2003.

Bujak, J. P. and Matsuoka, K.: Late Cenozoic dinoflagellate cyst zonation in the western and Northern Pacific, Palynology, 17, 7-25, 1986.

690 Bujak, J. P. and Mudge, D. C.: A high-resolution North Sea Eocene dinocyst zonation, Journal of the Geological Society London, 151, 449-462, 1994.

Clyde, W. C., Wilf, P., Iglesias, A., Slingerland, R. L., Barnum, T., Bijl, P. K., Bralower, T. J., Brinkhuis, H., Comer, E. E., Huber, B. T., Ibañez-Mejia, M., Jicha, B. R., Krause, J. M., Schueth, J. D., Singer, B. S., Raigemborn, M. S., Schmitz, M. D., Sluijs, A. and Zamaloa, M. C.: New age constraints for the Salamanca Formation and lower Río Chico Group in the western

695 San Jorge Basin, Patagonia, Argentina: Implications for cretaceous-paleogene extinction recovery and land mammal age correlations, 126(3-4), 289-306, doi:10.1130/B30915.1, 2014.

Correia, V. F., Riding, J. B., Henriques, M. H., Fernandes, P., Pereira, Z. and Wiggan, N. J.: The middle Jurassic palynostratigraphy of the northern Lusitanian Basin, Portugal, Newsletters on Stratigraphy, 52(1), 73-79, doi:10.1127/nos/2018/0471, 2019.

700 Costa, L. I. and Davey, R. J.: Dinoflagellate cysts of the Cretaceous system, in: A stratigraphix index of dinoflagellate cysts, in: A stratigraphix index of dinoflagellate cysts, edited by A. J. Powell., British Micropaleontological Society Publications series, London, UK, 99-154, 1992.

Costa, L. I. and Downie, C.: The Wetzeliellaceae; Palaeogene dinoflagellates, in: Proceedings of the 4th International Palynological Conference, Lucknow, 34-46, 1979. 
https://doi.org/10.5194/essd-2021-158

Preprint. Discussion started: 8 July 2021

(c) Author(s) 2021. CC BY 4.0 License.

(c) (i)

705 Cramwinckel, M. J., Huber, M., Kocken, I. J., Agnini, C., Bijl, P. K., Bohaty, S. M., Frieling, J., Goldner, A., Hilgen, F. J., Kip, E. L., Peterse, F., van der Ploeg, R., Röhl, U., Schouten, S. and Sluijs, A.: Synchronous tropical and deep ocean temperature evolution in the Eocene, Nature, 559, 382-386, 2018.

Cramwinckel, M. J., van der Ploeg, R., Bijl, P. K., Peterse, F., Bohaty, S. M., Röhl, U., Schouten, S., Middelburg, J. J. and Sluijs, A.: Harmful algae and export production collapse in the equatorial Atlantic during the zenith of Middle Eocene Climatic Optimum warmth, , 47(3), 247-250, doi:10.1130/G45614.1, 2019.

Crouch, E. M., Willumsen, P. S., Kulhanek, D. K. and Gibbs, S.: A revised Paleocene (Teurian) dinoflagellate cyst zonation from eastern New Zealand, Palaeogeography, Palaeoclimatology, Palaeoecology, 202, 47-79, 2014.

Crouch, E. M., Shepherd, C. L., Morgans, H. E. G., Naafs, B. D. A., Dallanave, E., Phillips, A., Hollis, C. J. and Pancost, R. D.: Climatic and environmental changes across the early Eocene climatic optimum at mid-Waipara River, Canterbury Basin,

715 New Zealand, Earth-Science reviews, 200, doi:10.1016/j.earscirev.2019.102961, 2020.

Dallanave, E., Bachtadse, V., Crouch, E. M., Tauxe, L., Shepherd, C. L., Morgans, H. E. G., Hollis, C. J., Hines, B. R. and Sugisaki, S.: Constraining early to middle Eocene climate evolution of the southwest Pacific and Southern Ocean, Earth and Planetary Science Letters, 433, 380-392, doi:10.1016/j.eps1.2015.11.010, 2016.

Davey, R. J.: Dinocyst stratigraphy of the latest Jurassic to Early Cretaceous of the Haldager No. 1 borehole, Denmark, 720 Danmarks Geologiske Undersögelse, Series B, 6, 1-57, 1982.

Davey, R. J.: A summary of the palynology of the lower Hauterivian (Lower Cretaceous) from Speeton, east England, Neues Jahrbuch für Paläontologische Abhandlungen, 122(1), 83-93, 2001.

Davey, R. J.: Marine Apto-Albian palynomorphs from Holes 400A and 402A, IPOD Leg 48, northern Bay of Biscay, in: Init. Rep. DSDP vol. 48, edited by L. Montardert et al., DSDP, Washington, USA., 1979.

725 Davey, R. J. and Verdier, J.-P.: An investigation of microplankton assemblages from the Albian of the Paris Basin, Verh., .Ned.Akad.Wet., Afd.Natuurkd., Eerste Reeks, 26, 1-58, 1971.

De Lira Mota, M. A., Harrington, G. and Dunkley Jones, T.: Organic-walled dinoflagellate cyst biostratigraphy of the upper Eocene to lower Oligocene Yazoo Formation, US Gulf Coast, Journal of Micropalaeontology, 39(1), 1-26, doi:10.5194/jm39-1-2020.

730 De Schepper, S. and Head, M. J.: Age calibration of dinoflagellate cyst and acritarch events in the Pliocene-Pleistocene of the eastern North Atlantic (DSDP Hole 610A), Stratigraphy, 5(2), 137-161, 2008.

De Schepper, S. and Head, M. J.: Pliocene and pleistocene dinoflagellate cyst and acritarch zonation of DSDP Hole 610A, Eastern North Atlantic, Palynology, 33, 179-218, 2009.

De Schepper, S., Beck, K. M. and Mangerud, G.: Late Neogene dinoflagellate cyst and acritarch biostratigraphy for Ocean 735 Drilling Program Hole 642B, Norwegian Sea, Review of Palaeobotany and Palynology, 236, 12-32, doi:10.1016/j.revpalbo.2016.08.005, 2017. 
https://doi.org/10.5194/essd-2021-158

Preprint. Discussion started: 8 July 2021

(c) Author(s) 2021. CC BY 4.0 License.

De Vernal, A. and Mudie, P. J.: Late Pliocene to Holocene palynostratigraphy at ODP Site 645, Baffin Bay, edited by S. P. Srivastava, M. Arthur, and B. Clement, proceedings of the ODP,scientific results, Leg 104, College Station, Texas, USA., 1989.

740 De Vernal, A., Londeix, L., Mudie, P. J., Harland, R., Morzadec-Kerfourn, M. T., Turon, J.-L. and Wrenn, J. H.: Quaternary organic-walled dinoflagellate cysts of the North Atlantic Ocean and adjacent seas: ecostratigraphy and biostratigraphy, in: Neogene and Quaternary dinoflagellate cysts and acritarchs, edited by M. J. Head and J. H. Wrenn, AASP Foundation, 289329, 1992.

De Verteuil, L. and Norris, G.: Miocene dinoflagellate stratigraphy and systematics of Maryland and Virginia,

745 Micropaleontology, 1-172, 1996.

Dimter, A. and Smelror, M.: Callovian (Middle Jurassic) marine microplankton from southwestern Germany: Biostratigraphy and paleoenvironmental interpretations, Palaeogeography, Palaeoclimatology, Palaeoecology, 80(3-4), 173-195, doi:10.1016/0031-0182(90)90131-P, 1990.

Dodsworth, P.: Trans-Atlantic dinoflagellate cyst stratigraphy across the Cenomanian-Turonian (Cretaceous) Stage boundary,

750 Journal of Micropaleontology, 19, 69-84, 2000.

Duffield, S. L. and Stein, J. A.: Peridiniacean-dominated cyst assemblage from the Miocene of the Gulf of Mexico shelf, offshore Louisiana, American Association of Stratigraphic Palynologists Contribution Series, 17, 27-45, 1986.

Duque-Herrera, A.-F., Helenes, J., Pardo-Trujillo, A., Flores-Villarejo, J.-A. and Sierro-Sánchez, F.-J.: Miocene biostratigraphy and paleoecology from dinoflagellates, benthic foraminifera and calcareous nannofossils on the Colombian

755 Pacific coast, Marine Micropaleontology, 141, 42-54, doi:10.1016/j.marmicro.2018.05.002, 2018.

Duxbury, S.: A study of dinoflagellate cysts and acritarchs from the Lower Green- sand (Aptian to Lower Albian) of the Isle of Wight, southern England, Palaeontographica, Abt.B, 186, 18-80, 1983.

Duxbury, S.: A palynological zonation scheme for the Lower Cretaceous - United Kingdom Sector, Central North Sea, Neues Jahrb.Geol.Palaontol.Abh., 219(1-2), 95-137, 2001.

760 Dybkjær, K. and Piasecki, S.: A new Neogene biostratigraphy for Denmark, Geological Survey of Denmark and Greenland Bulletin, 1-29, 2008.

Dybkjær, K. and Piasecki, S.: Neogene dinocyst zonation for the eastern North Sea Basin, Denmark, Review of Palaeobotany and Palynology, 161(1-2), 1-29, doi:10.1016/j.revpalbo.2010.02.005, 2010.

Egger, L. M., Sliwinska, K. K., van Peer, T. E., Liebrand, D., Lippert, P. C., Friedrich, O., Wilson, P. A., Norris, R. D. and

765 Pross, J.: Magnetostratigraphically-calibrated dinoflagellate cyst bioevents for the uppermost Eocene to lowermost Miocene of the western North Atlantic (IODP Expedition 342, Paleogene Newfoundland sediment drifts), Review of Palaeobotany and Palynology, 234, 159-185, doi:10.1016/j.revpalbo.2016.08.002, 2016.

Eldrett, J. S. and Harding, I. C.: Palynological analyses of Eocene to Oligocene sediments from DSDP Site 338, Outer Vøring Plateau, Marine Micropaleontology, 73(3-4), 226-240, 2009. 
https://doi.org/10.5194/essd-2021-158

Preprint. Discussion started: 8 July 2021

(c) Author(s) 2021. CC BY 4.0 License.

(c) (i)

Eldrett, J. S., Harding, I. C., Firth, J. V. and Roberts, A. P.: Magnetostratigraphic calibration of Eocene-Oligocene dinoflagellate cyst biostratigraphy from the Norwegian-Greenland Sea, Marine Geology, 204(1-2), 91-127, 2004.

Eldrett, J. S., Harding, I. C., Wilshaw, R. and Xuan, C.: A new high northern latitude dinocyst-based magneto-biostratigraphic calibration for the Norwegian-Greenland Sea, Newsletters on Stratigraphy, 52(4), 435-460, 2019.

Ellegaard, M.: Variations in dinoflagellate cyst morphology under conditions of changing salinity during the last 2000 years in the Limfjord, Denmark, Review of Palaeobotany and Palynology 109(1), 65-81, 2000.

Eshet, Y., Moshkovitz, S., Habib, D., Benjamini, C. and Magaritz, M.: Calcareous nannofossil and dinoflagellate stratigraphy across the Cretaceous/Tertiary boundary at Hor Hahar, Israel, Marine Micropaleontology, 18(3), 199-228, doi:10.1016/03778398(92)90013-A, 1992.

Feist-Burkhardt and S. Monteil, E.: Dinoflagellate cysts from the Bajocian stratotype (Calvados, Normandy, western France).

780 Kystes de dinoflagellés du stratotype du Bajocien (Calvados, Normandie, France), Bulletin du Centre de recherches Elf exploration production, 21(1), 31-105, 1997.

Feist-Burkhardt, S.: Dinoflagellate assemblages of the Hausen coreholes (Aalenian to Early Bajocian), southwest Germany, Bull. Centres Rech. Explor.-Prod. Elf-Aquitaine, 14(2), 611-633, 1990.

Fensome, R. A., Taylor, F. J. R., Norris, G., Sarjeant, W. A. S., Wharton, D. I. and Williams, G. L.: A Classification of Modern 785 and Fossil Dinoflagellates, edited by G. Dinkins, Micropalaeontology, Special Paper, Salem., 1993.

Fensome, R. A., Crux, J. A., Gard, G., MacRae, R. A., Williams, G. L., Thomas, F. C., Fiorini, F. and Wach, G.: The last 100 million years on the Scotian Margin, offshore eastern Canada: an event-stratigraphic scheme emphasizing biostratigraphic data, Atlantic Geology, 44, 93-126, 2008.

Firth, J. V.: Upper middle Eocene to Oligocene dinoflagellate biostratigraphy and assemblage variations in Hole 913B,

790 Greenland Sea, in: Thiede, J., Myrhe, A.M., Firth, J.V., Johnson, G.L., Ruddiman, W.F.(Eds.) Proceedings of the Ocean Drilling Program.Scientific Results, 203-242, 1996.

Firth, J. V., Eldrett, J. S., Harding, I. C., Coxall, H. K. and Wade, B. S.: Integrated biomagnetochronology for the palaeogene of ODP Hole 647A: Implications for correlating palaeoceanographic events from high to low latitudes, Geological Society Special Publication, 2013.

795 Frieling, J., Iakovleva, A. I., Reichart, G. J., Aleksandrova, G. N., Gnibidenko, Z. N., Schouten, S. and Sluijs, A.: PaleoceneEocene warming and biotic response in the epicontinental West Siberian Sea, Geology, 42, 767-770, 2014.

Frieling, J. and Sluijs, A.: Towards quantitative environmental reconstructions from ancient non-analogue microfossil assemblages: Ecological preferences of Paleocene - Eocene dinoflagellates, Earth-Science Reviews, 185, 956-973, doi:10.1016/j.earscirev.2018.08.014, 2018.

800 Gradstein, F. M., Kristiansen, I. L., Loemo, L. and Kaminski, M. A.: Cenozoic foraminiferal and dinoflagellate cyst biostrtigraphy of the central North Sea, Micropaleontology, 38(2), 101-137, 1992.

Gradstein, F. M., Ogg, J. G., Schmitz, M. D. and Ogg, G. M.: The Geologic Time Scale 2012, 1-1144, Elsevier, Amsterdam, 2012. 
https://doi.org/10.5194/essd-2021-158

Preprint. Discussion started: 8 July 2021

(c) Author(s) 2021. CC BY 4.0 License.

(c) (i)

Gradstein, F. M., Ogg, J.G., Schmitz, M.D., and Ogg, G.M.: The Geologic Time Scale 2020, 1-1358, Elsevier, Amsterdam,

805

Micropaleontology, 59, 210-229, 2005.

Habib, D. and Drugg, W. S.: Dinoflagellate age of Middle Jurassic-Early Cretaceous sediments in the Blake-Bahama Basin, Deep Sea Drilling Project, vol.76, edited by F. M. Gradstein, R. E. Sheridan, and et al., U.S. Govt. Printing Office, Washington., 1983.

Habib, D. and Drugg, W. S.: Palynology of Sites 603 and 605, Leg 93, Deep Sea Drilling Project., In: van Hinte, J.E. et al.,

Deep Sea Drilling Project, Washington, Initial Reports, v.92, 751-775, 1987.

Harding, I. C., Smith, G. A., Riding, J. B. and Wimbledon, W. A. P.: Inter-regional correlation of Jurassic/Cretaceous boundary strata based on the Tithonian-Valanginian dinoflagellate cyst biostratigraphy of the Volga Basin, western Russia, Review of palaeobotany and palynology, 167(1), 82-116, doi:https://doi.org/10.1016/j.revpalbo.2011.07.002, 2011.

Harland, R.: Dinoflagellate biostratigraphy of Neogene and Quaternary sediments at holes 400/400A in the Bay of Biscay

(DSDP Leg 48), Initial Reports of the DSDP volume 48, 1979.

Harland, R.: Dinoflagellate cysts of the Quaternary system, in: A stratigraphix index of dinoflagellate cysts, edited by A. J.

Powell., British Micropaleontological Society Publications series, London, UK, 253-273, 1992.

Head, M. J.: Pollen and dinoflagellates from the Red Crag at Walton-on-the-Naze, Essex: Evidence for a mild climatic phase during the early Late Pliocene of eastern England, Geological Magazine, 135(6), 803-817, 1998.

825 Head, M. J. and Norris, G.: Palynology and dinocyst stratigraphy of the Eocene and Oligocene in ODP Leg 105, Hole 647A, Labrador Sea, edited by S. P. Srivastava, M. Arthur, and B. Clement, Proceedings of the ODP, Scientific Results, Leg 105, College Station, Texas., 1989.

Head, M. J. and Norris, G.: New species of dinoflagellate cysts and other palynomorphs from the latest Miocene and Pliocene of DSDP Hole 603C, Western North Atlantic, Journal of Palaeontology, 77, 1-15, 2003.

830 Heilmann-Clausen, C.: Dinoflagellate stratigraphy of the uppermost Danian to Ypresien in the Viborg I borehole, central Jylland, Denmark, Danmarks Geologische untersogelse A, 7, 1-69, 1985.

Heilmann-Clausen, C.: Lower Cretaceous dinoflagellate biostratigraphy in the Danish Central Trough, Danmarks Geologische untersogelse A, 17, 1-1-89, 1987.

Heilmann-Clausen, C. and Van Simaeys, S.: Dinoflagellate cysts from the Middle Eocene to ?lowermost Oligocene succession

835 in the Kysing research borehole, central Danish basin, Palynology, 29(1), 143-204, doi:10.1080/01916122.2005.9989606, 2005. 
https://doi.org/10.5194/essd-2021-158

Preprint. Discussion started: 8 July 2021

(c) Author(s) 2021. CC BY 4.0 License.

(c) (i)

Helby, R. and McMinn, A.: A preliminary report of Early Cretaceous dinocyst floras from Site 765, Argo Abyssal Plain, northwest Australia., edited by F. M. Gradstein et al., Proc. ODP, Sci. Results, 123, 407-420, College Station, TX., 1992.

Helby, R., Morgan, R. and Partridge, A. D.: A palynological zonation of the Australian Mesozoic, in: Studies in Australian

840 Mesozoic Palynology, edited by P. A. Jell., Mem. Assoc. Australas. Palaeontol., 1987.

Hoek, R. P., Eshet, Y. and Almogi-Labin, A.: Dinoflagellate cyst zonation of Campanian-Maastrichtian sequences in Israel, Micropaleontology, 42, 125-150, 1996.

Hollis, C. J., Crouch, E. M., Morgans, H. E. G., Handley, L., Baker, J. A., Creech, J., Collins, K. S., Gibbs, S. J., Huber, M., Schouten, S., Zachos, J. C. and Pancost, R. D.: Tropical sea temperatures in the high latitude South Pacific during the Eocene,

845 Geology, 37(2), 99-102, 2009.

Houben, A. J. P., Bijl, P. K., Pross, J., Bohaty, S. M., Passchier, S., Stickley, C. E., Röhl, U., Sugisaki, S., Tauxe, L., Van De Flierdt, T., Olney, M., Sangiorgi, F., Sluijs, A., Escutia, C. and Brinkhuis, H.: Reorganization of Southern Ocean plankton ecosystem at the onset of Antarctic glaciation, , 340(6130), 341-344, 2013.

Houben, A. J. P., Bijl, P. K., Guerstein, G. R., Sluijs, A. and Brinkhuis, H.: Malvinia escutiana, a new biostratigraphically

important Oligocene dinoflagellate cyst from the Southern Ocean, Review of palaeobotany and palynology, 165(3-4), 175, 2011.

Hoyle, T.M., Sala-Pérez, M., Sangiorgi, F.: Where should we draw the line between dinocyst "species"? Morphological continua in Black Sea dinocysts, Journal of Micropaleontology 38(1), 55-65, 2019.

Iakovleva, A.I., Brinkhuis, H., Cavagnetoo, C.: Late Paleocene-Early Eocene dinoflagellate cysts from the Turgay Strait,

855 KAzachstan; correlations across ancient seaways, Palaeogeography, Palaeoclimatology, Palaeoecology 172, 243-268, 2001.

Iakovleva, A. I. and Heilmann-Clausen, C.: Eocene dinoflagellate cyst biostratigraphy of research borehole 011-BP, Omsk region, southwestern Siberia, Palynology, 34(2), 195-232, 2010.

Ioannides, N. S., Colin, J.-P. and Jan du Chêne, R.: A preliminary investigation of Kimmeridgian dinoflagellates and ostracodes from Quercy, southwest France, Bull. Centres rech. Explor.-Prod. Elf-Aquitaine, 12(1), 471-491, 1988.

860 King, C., Iakovleva, A., Heilmann-Clausen, C. and Steurbaut, E.: Ypresian (early Eocene) stratigraphy of the Suvlu-Kaya reference section in the Bakhchisaray area (Crimea). 51(2), Newsletters on Stratigraphy, 51(2), 167-208, doi:10.1127/nos/2017/0384, 2018.

Kirsch, K. H.: Dinoflagellaten-Zysten aus der Oberkreide des Helvetikums und Nordultrahelvetikums von Oberbayern, Muenchner Geowiss.Abh., Reihe A, Geol.Palaeontol., 22, 1-306, 1991.

865 Köthe, A.: A revised cenozoic dinoflagellate cyst and calcareous nannoplankton zonation for the german sector of the southeastern north sea basin, Newsletters on Stratigraphy, 45(3), 189-220, doi:10.1127/0078-0421/2012/0021, 2012.

Köthe, A., Khan, A. M. and Ahsraf, M.: Biostratigraphy of the Surghar Range, Salt Range, Sulaiman Range and the Kohat area, Pakistan, according to Jurassic through Paleogene calcareous nannofossils and Paleogene dinoflagellates., Geol. Jb., Reihe B, 71, 3-87, 1988. 
https://doi.org/10.5194/essd-2021-158

Preprint. Discussion started: 8 July 2021

(c) Author(s) 2021. CC BY 4.0 License.

(c) (i)

870 Krijgsman, W., Hilgen, F. J., Langereis, C. G., Santarelli, A. and Zachariasse, W. J.: Late Miocene magnetostratigraphy, biostratigraphy and cyclostratigraphy in the Mediterranean, Earth and Planetary Science Letters, 136(3-4), 475-494, doi:10.1016/0012-821X(95)00206-R, 1995.

Kuhlmann, G., Langereis, C. G., Munsterman, D., Leeuwen, R.-J. van, Verreussel, R., Meulenkamp, J. E. and Wong, T. E.: Integrated chronostratigraphy of the Pliocene-Pleistocene interval and its relation to the regional stratigraphical stages in the southern North Sea region, Geologie en Mijnbouw, 85(1), 20-45, 2006.

Lebedeva, N. K., Aleksandrova, G. N., Shurygin, B. N., Ovechkina, M. N. and Gnibidenkoa, Z. N.: Paleontological and Magnetostratigraphic Data on Upper Cretaceous Deposits from Borehole no. 8 (Russkaya Polyana District, Southwestern Siberia), Stratigraphy and Geological Correlation, 21(1), 48-78, 2013.

Leereveld, H.: Dinoflagellate cysts from the Lower Cretaceous Rio Argos succession (southeast Spain), Utrecht University, 880 Laboratory of Palaeobotany and Palynology, Contributions series no 2, Utrecht., 1995.

Leereveld, H.: Upper Tithonian-Valanginian (Upper Jurassic-Lower Cretaceous) dinoflagellate cyst stratigraphy of the western Mediterranean, Cretaceous Research, 18(3), 385-420, 1997a.

Leereveld, H.: Hauterivian-Barremian (Lower Cretaceous) dinoflagellate cyst stratigraphy of the western Mediterranean, Cretaceous Research, 18(3), 421-456, 1997b.

885 Londeix, L. and Jan Du Chene, R.: Burdigalian dinocyst stratigraphy of the stratotypic area (Bordeaux, France), GEOBIOS, 31(3), 283-294, 1998.

Louwye, S., Head, M. J. and De Schepper, S.: Dinoflagellate cyst stratigraphy and Palaeoecology of the Pliocene in Northern Belgium, southern North Sea Basin, Geological Magazine 141, 353-378, 2004.

Louwye, S., Mertens, K. N. and Vercauteren, D.: New dinoflagellate cysts from the Miocene of the Porcupine Basin, offshore 890 southwest Ireland, Palynology, 32, 131-142, 2008.

Mao, S. and Mohr, B. A. R.: Late Cretaceous dinoflagellate cysts (?Santonian-Maestrichtian) from the Southern Indian Ocean (Hole 748C), edited by S. W. Wise and R. Schlich, Proceedings of the Ocean Drilling Program, Scientific results volume 120, College Station, TX, USA., 1992.

Marret, F., Bradley, L., de Vernal, A., Hardy, W., Kim, S.-Y., Mudie, P., Penaud, A., Pospelova, V., Price, A. M., Radi, T. 895 and Rochon, A.: From bi-polar to regional distribution of modern dinoflagellate cysts, an overview of their biogeography, Marine Micropaleontology, 159, doi:10.1016/j.marmicro.2019.101753, 2020.

Martini, E.: Standard Tertiary and Quaternary calcareous nannoplankton zonation, In Farinacci, A. (ed), Proceedings $2^{\text {nd }}$ International Conference Planktonic Microfossils Roma: Rome (ed. Tecnosci.) Vol. 2, p. 739-785, 1971.

Masure, E.: Berriasian to Aptian dinoflagellate cysts from the Galicia margin, offshore Spain, Sites 638 and 639, Leg 103,

900 edited by G. Boillot, E. L. Winterer, and et al., Proceedings of the Ocean Drilling Program, Scientific Results, Volume 103, College Station, Texas,., 1988.

Masure, E., Rauscher, R., Dejax, J., Schuler, M. and Ferre, B.: Cretaceous-Paleocene palynology from the Cote D'ivoireGhana Transform Margin, sites 959, 960, 961, and 962, Proc.Ocean Drill.Program Sci.Res., volume 159, 253-276, 1998. 
https://doi.org/10.5194/essd-2021-158

Preprint. Discussion started: 8 July 2021

(c) Author(s) 2021. CC BY 4.0 License.

(c) (i)

Matsuoka, K., Bujak, J. P. and Shimazaki, T.: Late Cenozoic dinoflagellate cyst biostratigraphy from the west coast of northern

Japan, Micropaleontology, 33, 214-229, 1987.

Matthiessen, J. and Brenner, W.: Dinoflagellate cyst ecostratigraphy of Pliocene-Pleistocene sediments from the Yermak Plateau (Arctic Ocean, Hole 911A), Proceedings of the Ocean Drilling Program, Scientific Results, vol 151, College Station, Texas, USA., 1996.

McLachlan, S. M. S., Pospelova, V. and Hebda, R. J.: Dinoflagellate cysts from the upper Campanian (Upper Cretaceous) of

Hornby Island, British Columbia, Canada, with implications for Nanaimo Group biostratigraphy and paleoenvironmental reconstructions, Marine Micropaleontology, 145, 1-20, doi:10.1016/j.marmicro.2018.10.002, 2018.

McMinn, A.: Neogene dinoflagellate distribution in the eastern Indian Ocean from Leg 123, Site 765 doi:10.2973/odp.proc.sr.123.120.1992, edited by F. M. Gradstein, J. N. Ludden, et al Proc. ODP, Sci. Results, volume 123, College Station, TX., 1992.

915 McMinn, A.: Neogene dinoflagellate cyst biostratigraphy from sites 815 and 823, Leg 133, northeastern Australian margin, edited by J. A. McKenzie, P. J. Davies, and A. Palmer-Julson, Proceedings of the Ocean Drilling Program, Scientific Results, volume 133, U.S. Government Printing Office, College Station, Texas., 1993.

McRae, R.A., Fensome, R.A., Williams, G.L.: Fossil dinoflagellate diversity, originations and extinctions and their significance, Canadian Journal of Botany 74(11), 1687-1694, 1996.

920 Mertens, K.N., Carbonell-Moore, C.: Introduction to Spiniferites Mantell 1850 special issue, Palynology 42, sup1, 1-9, 2018. Mertens, K. N., Takano, Y., Head, M. J. and Matsuoka, K.: Living fossils in the Indo-Pacific warm pool: A refuge for thermophilic dinoflagellates during glaciations, Geology, 42(6), 531-534, doi:10.1130/G35456.1, 2014.

Mohr, B. A. R. and Mao, S.: Maastrichtian dinocyst floras from Maud Rise and Georgia Basin (Southern Ocean): Their Stratigraphic and Palaeoenvironmental implications, Palynology, 21, 41-41-65, 1997.

925 Montanari, A., Bice, D. M., Capo, R., Coccioni, R., Deino, A., DePaolo, D. J., Emmanuel, L., Monechi, S., Renard, M. and Zevenboom, D.: Integrated stratigraphy of the Chattian to mid-Burdigalian pelagic sequence of the Contessa Valley (Gubbio, Italy), edited by G. S. O. and R. C. A. Montanari, Miocene Stratigraphy: an Integrated Approach, Elsevier, Amsterdam, the Netherlands., 1997.

Monteil, E.: Kystes de dinoflagellés index (Tithonique-Valanginien) du sud-est de la France: proposition d'une nouvelle 930 zonation palynologique, Rev. Paleobiol., 11, 299, 1992.

Monteil, E.: Dinoflagellate cyst biozonation of the Tithonian and Berriasian of south-east France. Correlation with the sequence stratigraphy, Bull. Centres Rech. Explor.-Prod. Elf Aquitaine, 17(1), 249-273, 1993.

Mudge, D. C. and Bujak, J. P.: An integrated stratigraphy for the Paleocene and Eocene of the North Sea., Geological Society Special Publication, 101, 1996.

935 Mudge, D. C. and Bujak, J. P.: Biostratigraphic evidence for evolving palaeoenvironments inthe Lower Paleogene of the Faeroe-Shetland Basin, Marine and Petroleum Geology, 18(5), 577-590, doi:10.1016/S0264-8172(00)00074-X, 2001. 
https://doi.org/10.5194/essd-2021-158

Preprint. Discussion started: 8 July 2021

(c) Author(s) 2021. CC BY 4.0 License.

(c) (i)

Mudie, P. J.: Palynology and dinoflagellate biostratigraphy of DSDP Leg 94, Sites 607 and 611, North Atlantic Ocean, Initial Reports of the DSDP vol.94, Washington, USA., 1987.

Nikitenko, B., Pestchevitskaya, E. B., Lebedeva, N. K. and Ilyina, V. I.: Micropalaeontological and palynological analyses

940 across the Jurassic-Cretaceous boundary on Nordvik Peninsula, Northeast Siberia, Newsletters on Stratigraphy, 42(3), 181$222,2008$.

Nøhr-Hansen, H., Sheldon, E., Dam, G.: A new biostratigraphic scheme for the Paleocene onshore West Greenland and its implications for the timing of the pre-volcanic evolution, Geological Society Special Publication 197, 111-156, 2002.

Nøhr-Hansen, H., Piasecki, S., Alsen, P.: A Cretaceous dinoflagellate cyst zonation for NE Greenland, Geological Magazine 945 157(10), 1658-1692, 2020.

Ogg, J. G. and Hinnov, L. A.: Cretaceous, in: Gradstein, F.M., Ogg, J.G., Schmitz, M.D., Ogg, G.M., The Geologic Time Scale 2012, Elsevier, Amsterdam., 2012a.

Ogg, J. G. and Hinnov, L. A.: Jurassic, edited by F. M. Gradstein, J. G. Ogg, M. D. Schmitz, and G. M. Ogg, Elsevier, Amsterdam., 2012b.

Olde, K., Jarvis, I., Pearce, M., Uličný, D., Tocher, B., Trabucho-Alexandre, J., Gröcke, D.: A revised Northern European Turonian (upper Cretaceous) dinoflagellate cyst biostratigraphy: Integrating palynology and carbon isotope events, Review of Palaeobotany and Palynology, 213, 1-16, 2015.

Oosting, A. M., Leereveld, H., Dickens, G. R., Henderson, R. A. and Brinkhuis, H.: Correlation of Barremian-Aptian (midCretaceous) dinoflagellate cyst assemblages between the Tethyan and Austral realms, Cretaceous Research, 27(6), 792-813, doi:10.1016/j.cretres.2006.03.012, 2006.

Petrizzo, M.R., Wade, B.S., Gradstein, F.M., Planktonic Foraminifera, in: Gradstein, F. M., Ogg, J. G., Schmitz, M. D. and Ogg, G. M.: The Geologic Time Scale 2012, Chapter 3, 74-87, Elsevier, Amsterdam, 2012.

Poulsen, N. E.: Jurassic dinoflagellate cyst biostratigraphy of the Danish Subbasin in relation to sequences in England and Poland; a preliminary review, Review of Palaeobotany and Palynology, 75(1), 1-32, 1992.

960 Poulsen, N. E.: Dinoflagellate cyst biostratigraphy of the Late Jurassic of Poland, GEOBIOS 17:401-407, 1994.

Poulsen, N. E.: Upper Bajocian to Callovian (Jurassic) dinoflagellate cysts from central Poland, Acta Geologica Polonica, 48(3), 237-245, 1998.

Poulsen, N.E., Riding, J.B., The Jurassic dinoflagellate cyst zonation of Subboreal Northwest Europe, Geological Survey of Denmark and Greenland Bulletin, 115-144, 2003.

965 Powell, A. J.: Latest Palaeogene and Earliest Neogene dinoflagellate cysts from the Lemme section, NW Italy, AASP contributions series, 17, 83-83-104, 1986.

Powell, A. J.: A modified dinoflagellate cyst biozonation for latest Palaeocene and earliest Eocene sediments from the central North Sea, Review of palaeobotany and palynology, 56(3-4), 327-344, doi:10.1016/0034-6667(88)90064-4, 1988.

Powell, A. J.: Dinoflagellate cysts of the Tertiary System, in: A stratigraphix index of dinoflagellate cysts, edited by A. J.

Powell., British Micropaleontological Society Publications series, London, UK, 1992. 
https://doi.org/10.5194/essd-2021-158

Preprint. Discussion started: 8 July 2021

(c) Author(s) 2021. CC BY 4.0 License.

Powell, A. J., Brinkhuis, H. and Bujak, J. P.: Upper Paleocene-lower Eocene dinoflagellate cyst sequence biostratigraphy of southeast England, edited by R. W. O. Knox, R. M. Corfield, and R. E. Dunay, Geol. Soc. Spec. Publ., 1996.

Prince, I. M., Jarvis, I., Pearce, M. A. and Tocher, B. A.: Dinoflagellate cyst biostratigraphy of the Coniacian-Santonian (Upper Cretaceous): New data from the English Chalk, Review of Palaeobotany and Palynology, 150(1-4), 59-96, doi:10.1016/j.revpalbo.2008.01.005, 2008.

Pross, J., Houben, A. J. P., Simaeys, S. van, Williams, G. L., Kotthoff, U., Coccioni, R., Wilpshaar, M. and Brinkhuis, H.: Umbria-Marche revisited: A refined magnetostratigraphic calibration of dinoflagellate cyst events for the Oligocene of the Western Tethys, Review of palaeobotany and palynology, 158, 213-235, 2010.

Quaijtaal, W. and Brinkhuis, H.: Pentadinium alabamensis: A new, unusual dinoflagellate from the early Oligocene of the Gulf

Coast, Alabama, USA, Review of Palaeobotany and Palynology, 175, 47-54, doi:10.1016/j.revpalbo.2012.03.002, 2012.

Quaijtaal, W., Donders, T. H., Persico, D. and Louwye, S.: Characterising the middle Miocene Mi-events in the Eastern North Atlantic realm: A first high-resolution marine palynological record from the Porcupine Basin, Palaeogeography, Palaeoclimatology, Palaeoecology, 399, 140-159, 2014.

Radmacher, W., Pérez-Rodríguez, I., Arz, J. A. and Pearce, M. A.: Dinoflagellate biostratigraphy at the Campanian985 Maastrichtian boundary in Zumaia, northern Spain, Cretaceous Research, 51, 309-320, doi:10.1016/j.cretres.2014.07.004, 2014a.

Radmacher, W., Tyszka, J., Mangerud, G. and Pearce, M. A.: Dinoflagellate cyst biostratigraphy of the Upper Albian to Lower Maastrichtian in the southwestern Barents Sea., Marine and Petroleum Geology, 57, 109-121, 2014b.

Radmacher, W., Mangerud, G. and Tyszka, J.: Dinoflagellate cyst biostratigraphy of Upper Cretaceous strata from two wells 990 in the Norwegian Sea, Review of Palaeobotany and Palynology, 216, 18-32, 2015.

Reichart, G.-J., Brinkhuis, H., Huiskamp, F. and Zachariasse, W. J.: Hyperstratification following glacial overturning events in the northern Arabian Sea, 19, PA2013, doi:10.1029/2003PA000900, 2004.

Riding, J. B. and Helby, R.: Early Jurassic (Toarcian) dinoflagellate cysts from the Timor Sea, Australia, Studies in Australian Mesozoic palynology II; Memoir of the Association of Australasian Palaeontologists 24, edited by J. R. Laurie and C. B. 995 Foster., 1-32, 2001a.

Riding, J. B. and Helby, R.: A selective reappraisal of Wanaea Cookson \& Eisenack 1958 (Dinophyceae), Studies in Australian Mesozoic palynology II; Memoir of the Association of Australasian Palaeontologists 24, edited by J. R. Laurie and C. B. Foster., 33-58, 2001b.

Riding, J. B. and Helby, R.: Phallocysta granosa sp. nov., a Mid Jurassic (Bathonian) dinoflagellate cyst from the Timor Sea,

1000 Australia., Studies in Australian Mesozoic palynology II; Memoir of the Association of Australasian Palaeontologists 24, edited by J. R. Laurie and C. B. Foster., 59-63, 2001c.

Riding, J. B. and Helby, R.: Microplankton from the Mid Jurassic (late Callovian) Rigaudella aemula Zone in the Timor Sea, north-western Australia., Studies in Australian Mesozoic palynology II; Memoir of the Association of Australasian Palaeontologists 24, edited by J. R. Laurie and C. B. Foster., 65-109, 2001d. 
https://doi.org/10.5194/essd-2021-158

Preprint. Discussion started: 8 July 2021

(c) Author(s) 2021. CC BY 4.0 License.

(c) (i)

1005 Riding, J. B. and Helby, R.: Dinoflagellate cysts from the Late Jurassic (Oxfordian) Wanaea spectabilis Zone in the Timor Sea region., Studies in Australian Mesozoic palynology II; Memoir of the Association of Australasian Palaeontologists 24, edited by J. R. Laurie and C. B. Foster., 111-140, 2001e.

Riding, J. B. and Helby, R.: Dinoflagellate cysts from the Late Jurassic (Kimmeridgian) Dingodinium swanense Zone in the North-West Shelf and Timor Sea, Australia., Studies in Australian Mesozoic palynology II; Memoir of the Association of

1010 Australasian Palaeontologists 24, edited by J. R. Laurie and C. B. Foster., 141-176, 2001f.

Riding, J. B. and Helby, R.: Marine microplankton from the Late Jurassic (Tithonian) of the north-west Australian region., Studies in Australian Mesozoic palynology II; Memoir of the Association of Australasian Palaeontologists 24, edited by J. R. Laurie and C. B. Foster., 177-220, 2001g.

Riding, J. B. and Thomas, J. E.: Dinoflagellate cyst stratigraphy of the Kimmeridge Clay (Upper Jurassic) from the Dorset 1015 Coast, Southern England, Palynology, 12, 65-88, 1988.

Riding, J.B. and Thomas, J.E.: Dinoflagellate cysts of the Jurassic System, in: A stratigraphix index of dinoflagellate cysts, edited by A. J. Powell., British Micropaleontological Society Publications series, London, UK, 7-98, 1992.

Riding, J. B. and Thomas, J. E.: Marine palynomorphs from the Staffin Bay and Staffin Shale formations (Middle-Upper Jurassic) of the Trotternish Peninsula, NW Skye., Scottish Journal of Geology, 33(1), 59-74, 1997.

1020 Riding, J. B., Mantle, D. J. and Backhouse, J.: A review of the chronostratigraphical ages of Middle Triassic to Late Jurassic dinoflagellate cyst biozones of the North West Shelf of Australia, Review of Palaeobotany and Palynology, 162(4), 543-575, doi:10.1016/j.revpalbo.2010.07.008, 2010.

Riley, L. A. and Fenton, J. P. G.: A dinocyst zonation for the Callovian to iddle Oxfordian succession (Jurassic) of northwest Europe, Palynology, 6, 193-202, 1982.

1025 Rochon, A., Lewis, J., Ellegaard, M., Harding, I.C.: The Gonyaulax spinifera (Dinophyceae) "complex": Perpetuating the paradox? Review of Palaeobotany and Palynology, 155 (1-2), pp. 52-60, 2009.

Sangiorgi, F., Bijl, P.K., Passchier, S., Salzmann, U., Schouten, S., McKay, R., Cody, R.D., Pross, J., Van De Flierdt, T., Bohaty, S.M., Levy, R., Williams, T., Escutia, C., Brinkhuis, H., Southern Ocean warming and Wilkes Land ice sheet retreat during the mid-Miocene, Nature Communications 9(1), 317, 2018.

1030 Schiøler, P.: New species of dinoflagellate cysts from Maastrichtian- Danian chalks of the Danish North Sea, Journal of Micropalaeontology, 12(1), 99-112, 1993.

Schreck, M. and Matthiessen, J.: Batiacasphaera bergenensis and Lavradosphaera elongata - new dinoflagellate cyst and acritarch species from the Miocene of the Iceland Sea (ODP Hole 907A), Review of Palaeobotany and Palynology, 211, 97106, 2014.

1035 Schreck, M., Matthiessen, J. and Head, M. J.: A magnetostratigraphic calibration of Middle Miocene through Pliocene dinoflagellate cyst and acritarch events in the Iceland Sea (Ocean Drilling Program Hole 907A), ,Review of Palaeobotany and Palynology 187, 66-94, doi:10.1016/j.revpalbo.2012.08.006, 2012. 
https://doi.org/10.5194/essd-2021-158

Preprint. Discussion started: 8 July 2021

(c) Author(s) 2021. CC BY 4.0 License.

(c) (i)

Schreck, M., Meheust, M., Stein, R. and Matthiessen, J.: Response of marine palynomorphs to Neogene climate cooling in the Iceland Sea (ODP Hole 907A), Marine Micropaleontology, 101, 49-67, doi:10.1016/j.marmicro.2013.03.003, 2013.

1040 Schreck, M., Nam, C., S. I., Clotten, Fahl, K., De Schepper, S., Forwick, M. and Matthiessen, J.: Neogene dinoflagellate cysts and acritarchs from the high northern latitudes and their relation to sea surface temperature, Marine Micropaleontology, 136, 51-65, doi:10.1016/j.marmicro.2017.09.003, 2017.

Shulgina, N. I., Burdykina, M. D., Basov, V. A. and Århus, N.: Distribution of ammonites, foraminifera and dinoflagellate cysts in the lower Cretaceous reference sections of the Khatanga Basin, and Boreal Valanginian biogeography, Cretaceous Research, 15, 1-16, 1994.

Skupien, P.: Albian non-calcareous dinoflagellates of the western Carpathians, Slovak Geological magazine, 10(3), 203-214, 2004.

Skupien, P. and Vasícek, Z.: Lower Cretaceous ammonite and dinocyst biostratigraphy and paleoenvironment of the Silesian Basin (outher western Carpathians), Geologica Carpathica, 53(3), 179-189, 2002.

1050 Slimani, H. and Louwye, S.: New dinoflagellate cyst species of the Microdinium and Phanerodinium Complexes (Evitt) from the Upper Cretaceous-Lower Paleogene Chalk Group in the Meer borehole, northern Belgium, Review of palaeobotany and palynology, 168(1), 41-50, 2011.

Śliwińska, K. K., Abrahamsen, N., Beyer, C., Brünings-Hansen, T., Thomsen, E., Ulleberg, K. and Heilmann-Clausen, C.: Bio- and magnetostratigraphy of Rupelian-mid Chattian deposits from the Danish land area, Review of palaeobotany and palynology, 172, 48-69, 2012.

Śliwińska, K.K., Jelby, M.E., Grundvåg, S.-A., Nohr-Hansen, H., Alsen, P., Olaussen, S.: Dinocyst stratigraphy of the Valanginian-Aptian Rurikfjellet and Helvetiafjellet formations on Spitsbergen, Arctic Norway, Geological Magazine, 157 (10), pp. 1693-1714, 2020.

Sluijs, A., Schouten, S., Pagani, M., Woltering, M., Brinkhuis, H., Sinninghe Damsté, J. S., et al.: Subtropical Arctic Ocean temperatures during the Palaeocene/Eocene Thermal Maximum, Nature, 441, 610-613, 2006.

Sluijs, A., Pross, J. and Brinkhuis, H.: From greenhouse to icehouse; organic walled dinoflagellate cysts as paleoenvironmental indicators in the Paleogene, Earth-Science Reviews, 68, 281-315, 2005.

Sluijs, A., Brinkhuis, H., Stickley, C. E., Warnaar, J., Williams, G. L. and Fuller, M.: Dinoflagellate cysts from the Eocene Oligocene transition in the Southern Ocean: Results from ODP Leg 189, edited by N. Exon and J. P. Kennett, Proceedings of the ODP, Scientific Results, Leg 189, U.S. Government Printing Office, College Station, Texas., 2003.

Sluijs, A., Brinkhuis, H., Schouten, S., Bohaty, S., John, C. M., Zachos, J. C., Reichart, G.-J., Sinninghe Damsté, J. S., Crouch, E. M. and Dickens, G. R.: Environmental precursors to rapid light carbon injection at the Palaeocene/Eocene boundary, , 450, 1218-1221, 2007.

Smelror, M.: Late Bathonian to Early Oxfordian dinoflagellate cyst stratigraphy of Jameson Land and Milne Land, East 
https://doi.org/10.5194/essd-2021-158

Preprint. Discussion started: 8 July 2021

(c) Author(s) 2021. CC BY 4.0 License.

(c) (i)

Smelror, M.: Bathonian to early Oxfordian dinoflagellate cysts and acritarchs from Kong Karls Land, Svalbard, Review of palaeobotany and palynology, 56(3-4), 275-303, doi:10.1016/0034-6667(88)90061-9, 1988b.

Smelror, M.: Jurassic stratigraphy of the western Barents Sea region: a review., GEOBIOS, 17, 441-451, 1994.

Smelror, M. and Dietl, G.: Dinoflagellates cysts of the Bathonian/Callovian boundary beds in Southern Germany, GEOBIOS, 1075 17, 453-459, 1994.

Smelror, M. and Lominadze, T. A.: Callovian dinoflagellate cysts from the Caucasus, U.S.S.R., N. Jb. Geol. Palõont., Abh., 178(2), 147-166, 1989.

Smelror, M., Århus, N., Meléndez, G. and Lardies, M. Q.: A reconnaissance study of Bathonian to Oxfordian (Jurassic) dinoflagellates and acritarchs from the Zaragoza region (NE Spain) and Figueira da Foz (Portugal), Rev. Esp. Micropaleont., 1080 23(2), 47-82, 1991.

Soliman, A., Coric, S., Head, M. J., Piller, W. E. and El Beialy, S. Y.: Lower and Middle Miocene biostratigraphy, Gulf of Suez, Egypt based on dinoflagellate cysts and calcareous nannofossils, Palynology, 36(1), 38-79, 2012.

Steeman, T., De Weirdt, J., Smith, T., De Putter, T., Mees, F. and and Louwye, S.: Dinoflagellate cyst biostratigraphy and palaeoecology of the early Paleogene Landana reference section, Cabinda Province, Angola, Palynology, 44(2), 280-309, 1085 doi:10.1080/01916122.2019.1575091, 2020.

Stover, L. E. and Hardenbol, J.: Dinoflagellates and depositional sequences in the Lower Oligocene (Rupelian) Boom Clay Formation, Belgium, Bulletin de la Société belge de géologie, 102(1-2), 5-77, 1994.

Strauss, C. and Lund, J. J.: A Middle Miocene dinoflagellate cyst microflora from Papendorf near Hamburg, Germany, Mitt. Geol.-Palõont. Inst. univ. Hamburg, 157-189, 1992.

1090 Thorn, V. C., Riding, J. B. and Francis, J. E.: The Late Cretaceous dinoflagellate cyst Manumiella: Biostratigraphy, systematics, and palaeoecological signals in Antarctica, Review of palaeobotany and palynology, 156, 436-448, 2009.

Tocher, B. A.: Campanian to Maestrichtian dinoflagellate cysts from the United States Atlantic margin, Deep Sea Drilling Project Site 612., Initial reports DSDP, Leg 95, 419-428, 1987.

Tocher, B. A. and Jarvis, I.: Dinoflagellate cyst distribution and stratigraphy of the Lower- Middle Cenomanian (Upper 1095 Cretaceous) at Fumichon, Normandy, northern France, Revue de Micropaleontologie, 37(3), 223-232, 1994.

Tocher, B. A. and Jarvis, I.: Dinocyst distributions and stratigraphy of two Cenomanian-Turonian boundary (Upper Cretaceous) sections from the western Anglo-Paris Basin, Journal of Micropaleontology, 14(2), 97-105, doi:10.1144/jm.14.2.97, 1995.

Tocher, B. A. and Jarvis, I.: Dinoflagellate cyst distributions and the Albian-Cenomanian boundary (mid-Cretaceous) at 1100 Cordebugle, NW France and Lewes, southern England, Journal of Micropaleontology, 15(1), 55-67, doi:10.1144/jm.15.1.55, 1996.

Torricelli, S.: Lower Cretaceous dinoflagellate cyst and acritarch stratigraphy of the Cismon APTICORE (southern Alps, Italy), Review of palaeobotany and palynology, 108(3-4), 213-266, doi:10.1016/S0034-6667(99)00041-X, 2000. 
https://doi.org/10.5194/essd-2021-158

Preprint. Discussion started: 8 July 2021

(c) Author(s) 2021. CC BY 4.0 License.

(c) (i)

Torricelli, S.: Dinoflagellate cyst stratigraphy of the Scisti a Fucoidi Formation (Early Cretaceous) from Piobbico, Central

Italy: calibrated events for the Albian of the Tethyan Realm., Revista Italiana di Paleontologia e Stratigrafia, 112(1), 95-112, 2006.

Torricelli, S. and Rosa Amore, M.: Dinoflagellate cysts and calcareous nannofossils from the upper cretaceous Saraceno formation (Calabria, Italy): Implications about the history of the Liguride Complex, Rivista Italiana di Paleontologia e Stratigrafia, 109(3), 499-516, 2003.

1110 Torricelli, S., Knezaurek, G. and Biffi, U.: Sequence biostratigraphy and paleoenvironmental reconstruction in the Early Eocene Figols Group of the Trenp-Graus Basin (South-Central Pyrenees, Spain), Palaeogeography, Palaeoclimatology, Palaeoecology, 232(1), 2006.

Türkecan, A. T., Munsterman, D., Işik, U., Altiner, D., Pinar, M., Çevik, T. and Alay, Z.: Dinoflagellate cyst biostratigraphy of Miocene strata in the Adana Basin, Eastern Mediterranean, Turkey, Palynology, 42(4), 516-539, 1115 doi:10.1080/01916122.2017.1403389, 2018.

Van De Schootbrugge, B., Houben, A. J. P., Ercan, F. E. Z., Verreussel, R., Kerstholt, S., Janssen, N. M. M., Nikitenko, B. and Suan, G.: Enhanced Arctic-Tethys connectivity ended the Toarcian Oceanic Anoxic Event in NW Europe., Geological Magazine, 157(10), 1593-1611, doi:10.1017/S0016756819001262, 2019a.

Van De Schootbrugge, B., Richoz, S., Pross, J., Luppold, F. W., Hunze, S., Wonik, T., Blau, J., Meister, C., van der Weijst, 1120 C. M. H., Suan, G., Fraguas, A., Fiebig, J., Herrle, J. O., Guex, J., Little, C. T. S., Wignall, P. B., Püttmann, W. and Oschmann, W.: The Schandelah Scientific Drilling Project: A 25-million year record of Early Jurassic palaeo-environmental change from northern Germany, Newsletters on Stratigraphy, 52(3), 249-296, $2019 \mathrm{~b}$.

Van Helmond, N. A. G. M., Sluijs, A., Papadomanolaki, N. M., Plint, A. G., Gröcke, D. R., Pearce, M. A., Eldrett, J. S., Trabucho-Alexandre, J., Walaszczyk, I., Van De Schootbrugge, B. and Brinkhuis, H.: Equatorward phytoplankton migration 1125 during a cold spell within the Late Cretaceous super-greenhouse, Biogeosciences, 13(9), 2859-2872, doi:10.5194/bg-13-28592016, 2016.

Van Hinsbergen, D. J. J., De Groot, L. V., Van Schaik, S. J., Spakman, W., Bijl, P. K., Sluijs, A., Langereis, C. G. and Brinkhuis, H.: A paleolatitude calculator for paleoclimate studies, Plos One, 10(6), 2015.

Van Mourik, C. A. and Brinkhuis, H.: The Massignano Eocene-Oligocene golden spike section revisited, Stratigraphy, 2, 13$113030,2005$.

Van Mourik, C. A., Brinkhuis, H. and Williams, G. L.: Mid-to late Eocene organic-walled dinoflagellate cysts from ODP Leg 171B, offshore Florida., Geol. Soc. Spec. Publ., 183, 225, 2001.

Van Simaeys, S., de Man, E., Vandenberghe, N., Brinkhuis, H. and Steurbaut, E.: Stratigraphic and palaeoenvironmental analysis of the Rupelian-Chattian transition in the type region: evidence from dinoflagellate cysts, foraminifera and calcareous 1135 nannofossils, Palaeogeography, Palaeoclimatology, Palaeoecology, 208, 31-58, 2004.

Van Simaeys, S., Munsterman, D. and Brinkhuis, H.: Oligocene dinoflagellate cyst biostratigraphy of the southern North Sea Basin, Review of Palaeobotany and Palynology, 134(1-2), 105-128, doi:10.1016/j.revpalbo.2004.12.003, 2005. 
https://doi.org/10.5194/essd-2021-158

Preprint. Discussion started: 8 July 2021

(c) Author(s) 2021. CC BY 4.0 License.

Vellekoop, J., Smit, J., van de Schootbrugge, B., Weijers, J. W. H., Galeotti, S., Sinninghe Damsté, J. S. and Brinkhuis, H.: Palynological evidence for prolonged cooling along the Tunisian continental shelf following the K-Pg boundary impact.,

1140 Palaeogeography, Palaeoclimatology, Palaeoecology, 426, 216-228, 2015.

Versteegh, G. J. M.: The onset of major Northern Hemisphere glaciations and their impact on dinoflagellate cysts an acritarchs from the Singa section, Calabria (southern Italy) and DSDP Holes 607/607A (North Atlantic), Marine Micropaleontology, 30(4), 319-343, 1997.

Vieira, M., Jolley, D.: Stratigraphic and spatial distribution of palynomorphs in deep-water turbidites: A metastudy from the

1145 UK central North Sea Paleogene, Marine and Petroleum Geology 12, 104683, 2020.

Vieira, M., Casas-Gallego, M., Mahdi, S. and Fenton, J.: Impagidinium obscurum sp. nov., a marker dinoflagellate cyst for the Thanetian (Paleocene) of the North Sea and the Barents Sea., Palynology, 44(2), 382-390, doi:10.1080/01916122.2019.1630494, 2020.

Watkins, D.K., Raffi, I., Calcareous nannofossils, in: Gradstein, F. M., Ogg, J. G., Schmitz, M. D. and Ogg, G. M.: The 1150 Geologic Time Scale 2012, Chapter 3, 69-73, Elsevier, Amsterdam, 2012.

Westerhold, T., Marwan, N., Drury, A. J., Liebrand, D., Agnini, C., Anagnostou, E., Barnet, J. S. K., Bohaty, S. M., De Vleeschouwer, D., Florindo, F., Frederichs, T., Hodell, D. A., Holbourn, A. E., Kroon, D., Lauretano, V., Littler, K., Lourens, L. J., Lyle, M., Pälike, H., Röhl, U., Tian, J., Wilkens, R. H., Wilson, P. A. and Zachos, J. C.: An astronomically dated record of Earth's climate and its predictability over the last 66 million years, Science, 369(6509), 1383-1387, 1155 doi:10.1126/science.aba6853, 2020.

Williams, G. L., Damassa, S. P., Fensome, R. A. and Guerstein, G. R.: Wetzeliella and its allies - The "hole" story: A taxonomic revision of the Paleogene dinoflagellate subfamily Wetzelielloideae, Palynology, 39(3), 289-344, doi:10.1080/01916122.2014.993888, 2015.

Williams, G. L. and Bujak, J. P.: Distribution patterns of some North Atlantic Cenozoic dinoflagellate cysts., Marine 1160 Micropaleontology, 2, 223-234, 1977.

Williams, G. L., Stover, L. E. and Kidson, E. J.: Morphology and stratigraphic ranges of selected Mesozoic-Cenozoic dinoflagellate taxa in the Northern Hemisphere, Pap. Geol. Surv. Can., 92(10), 1993.

Williams, G. L., Brinkhuis, H., Pearce., M. A., Fensome, R. A. and Weegink, J. W.: Southern Ocean and global dinoflagellate cyst events compared: Index events for the late Cretaceous - Neogene, edited by N. F. Exon, J. P. Kennett, and M. J. Malone,

1165 Proceedings of the ODP, scientific Results volume 189, 2004.

Williams, G. L., Fensome, R. A. and MacRae, R. A.: DINOFLAJ3, 2, 2017.

Willumsen, P. S.: Three new species of dinoflagellate cyst from Cretaceous-Paleogene (K-Pg) boundary sections at midWaipara River and Fairfield Quarry, South Island, New Zealand, Palynology, 36(SUPPL. 1), 48-62, doi:10.1080/01916122.2011.642260, 2012.

1170 Wilpshaar, M., Santarelli, A., Brinkhuis, H. and Visscher, H.: Dinoflagellate cysts and mid-Oligocene chronostratigraphy in the central Mediterranean region, Journal of the Geological Society of London, 153, 553-561, 1996. 
Woollam, R. and Riding, J. B.: Dinoflagellate cyst zonation of the English Jurassic, Report of the Institute of Geological sciences, 1-1-42, 1983.

Wrenn, J. H. and Kokinos, J. P.: Preliminary comments on Miocene through Pleistocene dinoflagellate cysts from De Soto 1175 Canyon, Gulf of Mexico, American Association of Stratigraphic Palynologists, Contributions Series, 17, 169-225, 1986.

Zegarra, M. and Helenes, J.: Changes in Miocene through Pleistocene dinoflagellates from the Eastern Equatorial Pacific (ODP Site 1039), in relation to primary productivity, Marine Micropaleontology, 81(3-4), 107-121, doi:10.1016/j.marmicro.2011.09.005, 2011.

Zevenboom, D.: Dinoflagellate cysts from the Mediterranean late Oligocene and Miocene, PhD thesis, Utrecht University, 1180 Utrecht, the Netherlands., 1995.

Zonneveld, K. A. F., Versteegh, G. J. M., Kasten, S., Eglinton, T. I., Emeis, K.-C., Huguet, C., Koch, B. P., De Lange, G. J., De Leeuw, J. W., Middelburg, J. J., Mollenhauer, G., Prahl, F. G., Rethemeyer, J. and Wakeham, S. G.: Selective preservation of organic matter in marine environments; Processes and impact on the sedimentary record, Biogeosciences, 7(2), 483-511, 2010.

1185 Zonneveld, K. A. F., Marret, F., Versteegh, G. J. M., Bogus, K., Bonnet, S., Bouimetarhan, I., Crouch, E., de Vernal, A., Elshanawany, R., Edwards, L., Esper, O., Forke, S., Grøsfjeld, K., Henry, M., Holzwarth, U., Kielt, J.-F., Kim, S.-Y., Ladouceur, S., Ledu, D., Chen, L., Limoges, A., Londeix, L., Lu, S.-H., Mahmoud, M. S., Marino, G., Matsouka, K., Matthiessen, J., Mildenhal, D. C., Mudie, P., Neil, H. L., Pospelova, V., Qi, Y., Radi, T., Richerol, T., Rochon, A., Sangiorgi, F., Solignac, S., Turon, J.-L., Verleye, T., Wang, Y., Wang, Z. and Young, M.: Atlas of modern dinoflagellate cyst distribution based on 2405 datapoints, Review of palaeobotany and palynology,191, 1-197, 2013. 